\title{
Arctic Ocean circulation, processes and water masses: A description of observations and ideas with focus on the period prior to the International Polar Year 2007-2009
}

\author{
Bert Rudels* \\ Finnish Meteorological Institute, Erik Palménin aukio 1, P.O. Box 503, FI-00101 Helsinki, Finland
}

\section{A R T I C L E I N F O}

Article history:

Available online 27 November 2013

\begin{abstract}
A B S T R A C T
The evolving knowledge of the Arctic Ocean, its hydrography and its water masses and their transformations and circulation is reviewed starting with the observations made on Fram 1893-1896 and extending to the International Polar Year (IPY) 2007-2009. The expeditions and observations after Fram to the mid 20th century as well as the more extensive and systematic studies of water masses and circulation made from ice stations and airborne expeditions from the late 1940s to the late 1970s are briefly described. The early concepts of the connections and exchanges between the Arctic Ocean and the world ocean are also discussed. In the 1980s scientific icebreakers were beginning to enter the inner parts of the Arctic Ocean and large international programmes were launched, culminating in the IPY. The changes in the Arctic Ocean, first noted in the Atlantic layer in 1990 and shortly after in the upper layers, are described. The exchanges between the Arctic Ocean and the surrounding seas through the four main openings, Fram Strait, Barents Sea, Bering Strait and the Canadian Arctic Archipelago as well the volume and freshwater balances of the Arctic Ocean are examined.
\end{abstract}

(c) 2013 Elsevier Ltd. All rights reserved.

\section{Introduction}

The Arctic Ocean is an enclosed ocean with extensive shelves making up $53 \%$ of its $9.5 \times 10^{12} \mathrm{~m}^{2}$ surface area (Jakobsson et al., 2004). The remaining part consists of two major basins, the Eurasian and the Amerasian (Canadian) basins, separated by the Lomonosov Ridge (Fig. 1). The Eurasian Basin is further divided into the Nansen and the Amundsen basins by the Gakkel Ridge and the Amerasian Basin into the Canada and Makarov basins by the Alpha and Medeleyev ridges. The Amundsen Basin is the deepest, reaching about $4500 \mathrm{~m}$, while the other three basins have maximum depths around $4000 \mathrm{~m}$. The Arctic Ocean is dominated by the severe high latitude climate and the deep basins are ice covered throughout the year. The Arctic Ocean, in spite of its name, is often considered a part of the Arctic Mediterranean Sea, forming the northernmost part of the North Atlantic (Sverdrup et al., 1942). It communicates with the North Atlantic through Fram Strait and the Barents Sea via the Nordic Seas and across the GreenlandScotland Ridge, and through the Canadian Arctic Archipelago via Baffin Bay and Davis Strait. Fram Strait is the only deep passage, $2600 \mathrm{~m}$, and the only one allowing for a two-way exchange. In the 200-300 m deep Barents Sea there is an inflow from the North

\footnotetext{
* Tel.: +358 505723354; fax: +358 932310125.

E-mail address: bert.rudels@fmi.fi
}

Atlantic via the Norwegian Sea to the Arctic Ocean, but a substantial recirculation to the Norwegian Sea takes place in the Bear Island Trough. The $125-230 \mathrm{~m}$ deep and narrow channels of the Canadian Arctic Archipelago are dominated by outflows from the Arctic Ocean. Through the shallow $(50 \mathrm{~m})$ and narrow $(85 \mathrm{~km})$ Bering Strait the Arctic Ocean is connected to the Pacific Ocean, which allows for an inflow of Pacific water and a communication between the North Atlantic and the North Pacific.

\section{Historical overview}

\subsection{The beginning}

The Arctic Ocean emerged out of the realms of myth and speculation with the drift of Fram 1893-1896 (Nansen, 1902). Before this expedition hopes of an ice free ocean and of large undiscovered land areas would not be abandoned. The Fram expedition discovered many of the most fundamental features of the Arctic Ocean. It is an enclosed ocean with extensive shelf areas and a deep central basin (Fig. 1). That the Arctic Ocean is deep came as a surprise and the party on Fram had to improvise to get enough rope to carry out soundings and water sampling. The Arctic Ocean was found stratified in salinity and the stability in the upper part was sufficiently strong to reduce the mixing with the water below, allowing the upper low salinity layer to be cooled to freezing tem- 

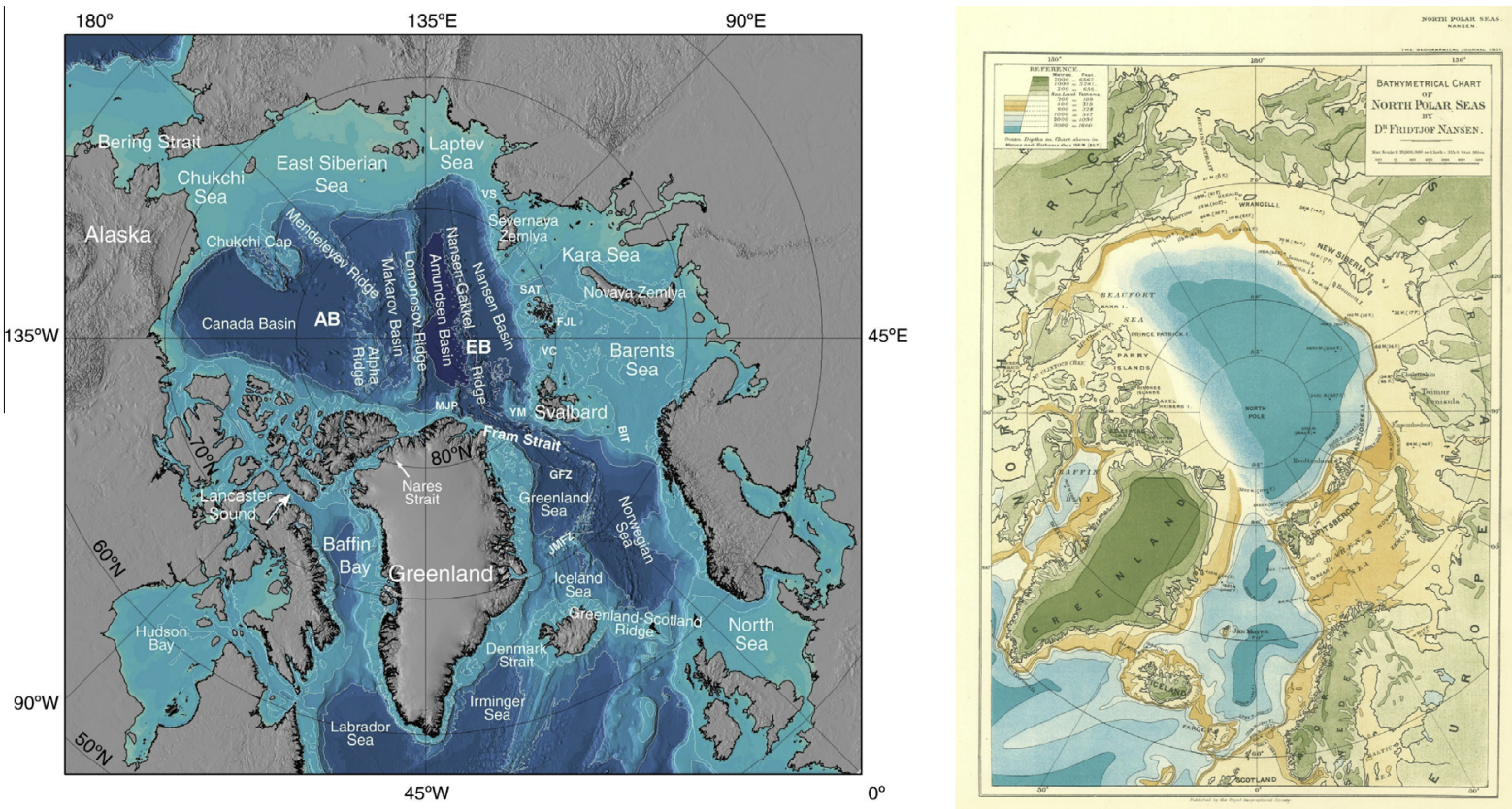

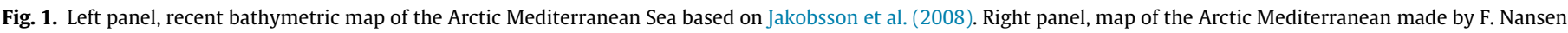
1897 after the drift of Fram 1893-1896.

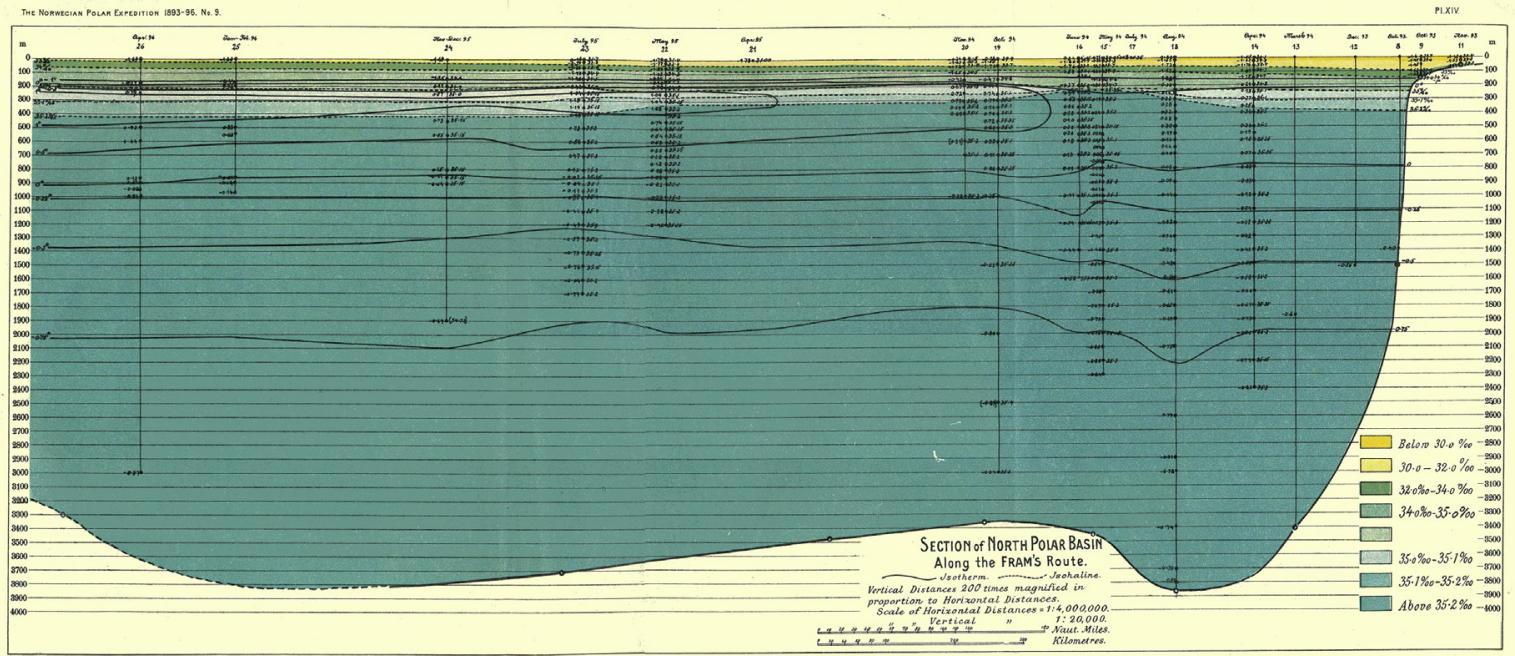

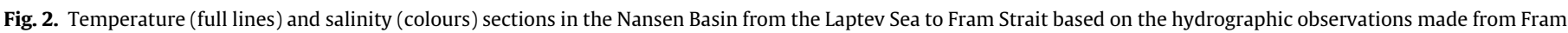
1893-1896. (from Nansen, 1902).

perature without deep overturning (Fig. 2). Ice is then formed in winter and persists throughout the year in the central part of the Arctic Ocean.

A warm subsurface layer was observed between $200 \mathrm{~m}$ and $700 \mathrm{~m}$ with temperature above $0^{\circ} \mathrm{C}$, and Nansen concluded that this layer was maintained by an inflow of warm Atlantic water through the passage between Greenland and Svalbard (later to be called Fram Strait). This was not entirely unexpected. It had been assumed (e.g. Petermann, 1865) that the heat carried northward by the Gulf Stream and its extensions in the North Atlantic would be sufficient to melt the sea ice and create an ice-free Arctic Ocean. This was now found not to be the case. The runoff from the Siberian rivers is large enough to isolate the heat in the Atlantic water from the surface, allowing sea ice to form and grow. A further observation made on the Fram expedition was that the ice drift deviated to the right of the wind direction. An observation that eventually led to the formulation of the theory of wind driven ocean currents (Ekman, 1905).

The salinity measured on the water samples taken from Fram showed a salinity increase towards the bottom, which made Nansen speculate about the possibility that freezing and brine rejection on the shelves could result in the formation and drainage of dense saline water into the deep Arctic Ocean. High bottom salinities had been found on the Barents Sea shelf, especially close to Novaya Zemlya (Knipovitch, 1905) and were presented by Nansen (1906). However, based on later observations made northwest of Svalbard from the sailing vessel Veslemøy in 1912 (Nansen, 1915), Nansen concluded that the salinities measured on the deep water samples taken from Fram were too high and he adopted the view that the deep waters of the Arctic Ocean derive from an 
inflow of dense, cold water, formed by winter convection in the Greenland Sea.

\subsection{Interlude}

After the Fram expedition studies were continued in the Barents Sea (Knipovitch, 1905; Nansen, 1906) and in the Greenland Sea (Nansen, 1906; Helland-Hansen and Nansen, 1909). During the second Fram expedition (1898-1902) under Otto Sverdrup several islands were charted in the Canadian Arctic Archipelago and the Severnaya Zemlya archipelago was discovered during the Russian Hydrographic Expedition of the Arctic (1910-1915). The effort by Amundsen to reach the inner Arctic Ocean and North Pole from Bering Strait with Maud (1919-1925) did not succeed, and Maud remained on the shelf in the East Siberian Sea. Harald Sverdrup's work on long waves and tides (Sverdrup, 1926) and Malmgren's studies of sea ice (Malmgren, 1927) were some of the oceanographic results from this expedition.

The Soviet icebreaker Sedov involuntarily almost repeated the drift of Fram between 1937 and 1940, and in 1931 an attempt by H. Wilkins to reach the North Pole under the ice using a discarded US submarine, Nautilus, was abandoned north of Fram Strait due to malfunction of the diving rudders. However, the most impressive achievement during the period was the launching of the first Soviet drifting ice station, North Pole 1, led by I.N. Papanin. It was established at the North Pole by aircrafts in May 1937. The station then drifted southward and exited through Fram Strait in the East Greenland Current, where the members were picked by two Soviet icebreakers in February 1938. The observations made from North Pole 1, Fram and Nautilus in the Arctic Ocean and from Belgica and Gjøa in the Greenland Sea formed the basis for the celebrated schematics, constructed by Wüst (1941), showing the temperature of the deep waters increasing from the Greenland Sea to the North Pole. This suggested a gradual heating of the dense water formed in the Greenland Sea by mixing with surrounding waters as it spreads into the Arctic Ocean (Fig. 3).

\subsection{A new start}

After the Second World War North Pole 1 was followed by many other drifting ice stations, most of them established by the Soviet Union, forming an impressive sequence of "North Pole" stations but also by the United States, e.g. T3, Alpha, ARLIS I \& II (Arctic Research Laboratory Ice Station), AIDJEX (Arctic Ice Dynamics Joint Experiment), and by Canada, e.g. CESAR (Canadian Experiment to Study the Alpha Ridge) and LOREX (Lomonosov Ridge Experiment). Each spring the Soviet Union also launched extensive airborne campaigns, SEVER, observing the upper layers over the entire Arctic Ocean. Most of this observational work conducted between the 1950 s and the 1970s is masterfully synthesised and presented in the Atlas of the Arctic Ocean (Gorshkov, 1980). Fig. 4 shows TS diagrams, revealing the characteristics of the water columns in different areas of the Arctic Mediterranean. Below we summarise some major findings during this period.

\subsubsection{Water masses and circulation}

The observations gathered on the many campaigns during the 1950s allowed for major summaries of the different water masses and their circulation in the Arctic Ocean (Timofeyev, 1960; Coachman and Barnes, 1961, 1962, 1963; Treshnikov and Baranov, 1972; Coachman and Aagaard, 1974; Treshnikov, 1997). The Arctic Ocean water masses can, simplistically, be separated vertically into three major layers with some important sub-divisions within these layers that will become apparent in due course.

(1) The Polar Surface Water (PSW) consisting of the Polar Mixed Layer (PML) and the halocline.

(2) The Atlantic water, historically identified as a subsurface layer bounded above and below by the $0{ }^{\circ} \mathrm{C}$ isotherm, and the intermediate waters below that can communicate freely over the Lomonosov Ridge.

(3) The deep and bottom waters in the different basins.

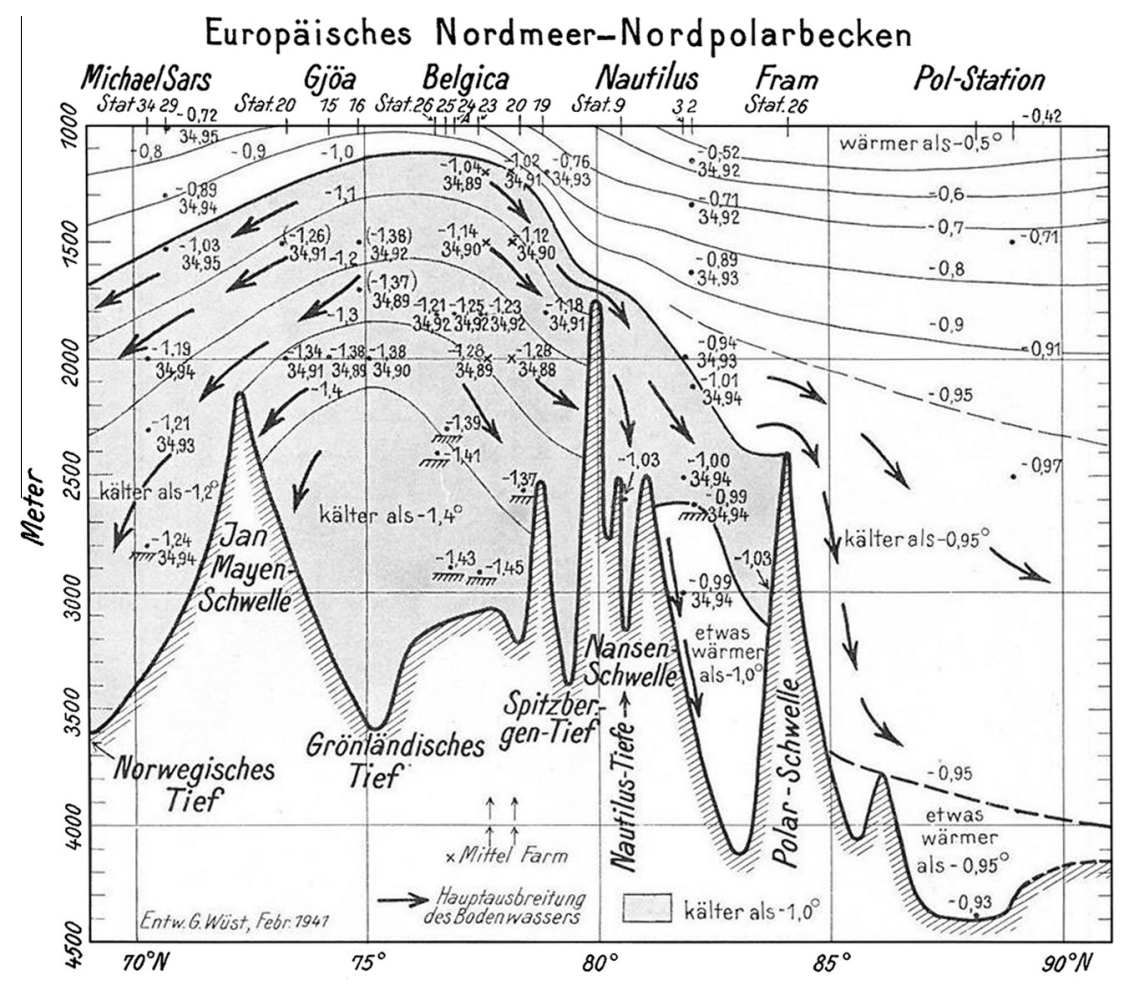

Fig. 3. Potential temperature section from the Nordic Seas to the North Pole based on data available from expeditions conducted before 1940 (from Wüst, 1941 ). 



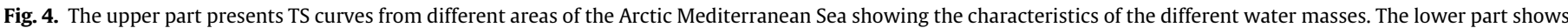
four temperature sections in the Arctic Ocean and the Nordic Sea. The different areas and the positions of the sections are indicated on the map (from Gorshkov, 1980).

The PML comprises the part of the water column that is homogenised during winter by freezing, brine release and haline convection. In summer the uppermost part of the PML becomes freshened and stratified by a seasonal melt water layer, which again is removed by freezing in fall.
Below the PML there is a layer characterised by a strong salinity increase with depth but with temperatures remaining close to freezing. This is the Arctic Ocean halocline. This cold water mass cannot be created by direct mixing between the PML and the underlying warm and saline Atlantic water but must have an 

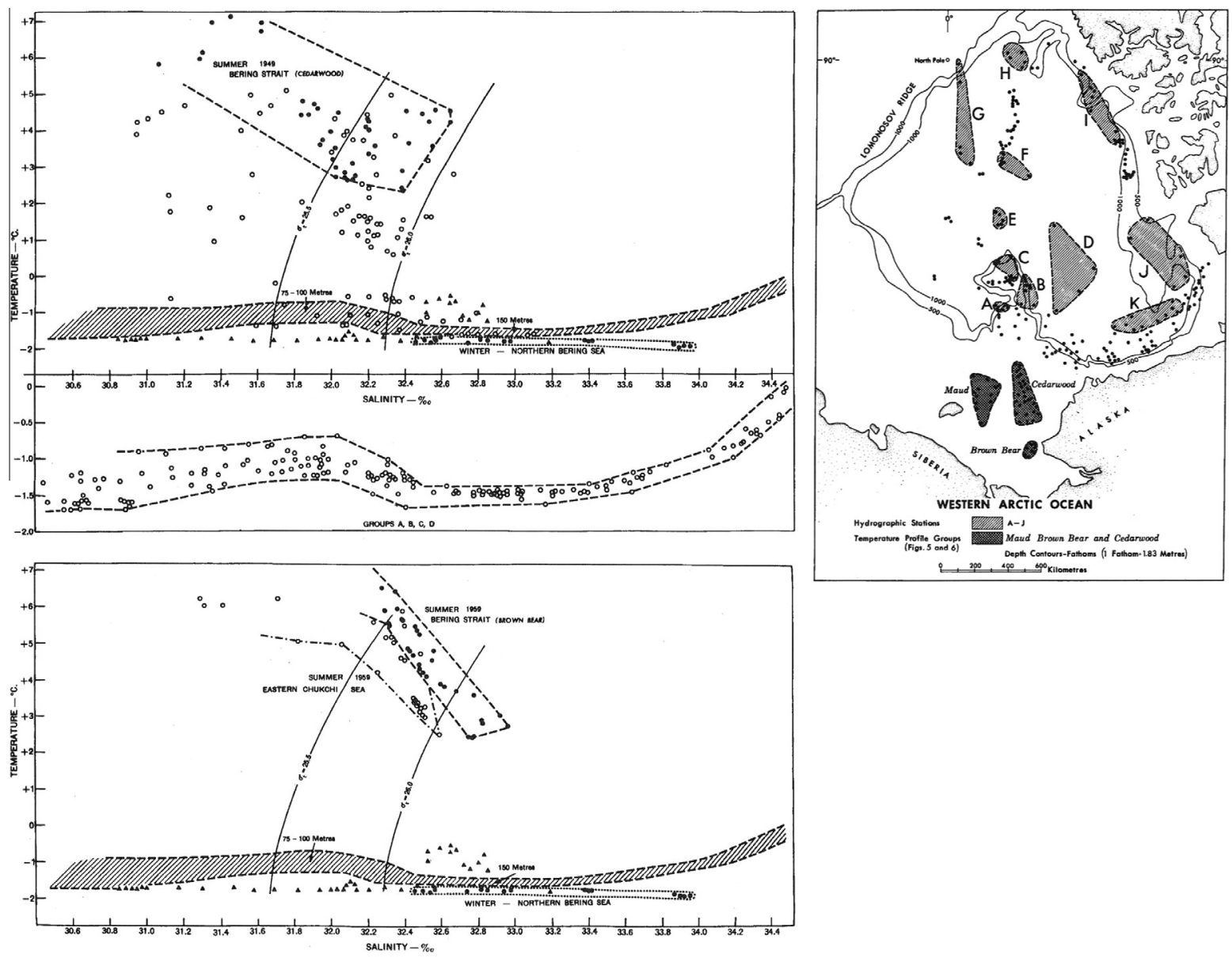

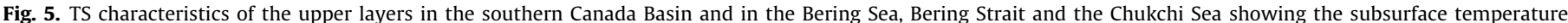

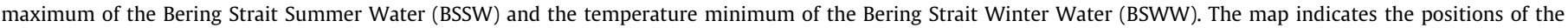
stations (from Coachman and Barnes, 1961).

advective origin. In the Amerasian Basin such advective sources are easy to find. Coachman and Barnes (1961) showed that the inflow of Pacific water, being less saline than the Atlantic water but commonly more saline than the PML found in the Amerasian Basin, would provide an intermediate layer, characterised by two temperature signals. An upper temperature maximum observed around $75 \mathrm{~m}$ derives from the Bering Sea Summer Water (BSSW), entering through the Bering Strait during summer, and a deeper temperature minimum located at $150 \mathrm{~m}$ is caused by the inflow of colder and more saline Bering Sea Winter Water (BSWW) (Fig. 5).

The Pacific water is mainly confined to the Amerasian Basin. In the Eurasian Basin the PML is more saline than in the Amerasian Basin because of the higher salinity of the Atlantic water and because the freshwater sources are limited to river runoff and ice melt. A cold halocline is nevertheless present, and since it cannot be formed as a mixing product from the PML and the Atlantic water, Coachman and Barnes (1962) suggested that Atlantic water is brought onto the shelves along deep canyons, e.g. the St. Anna Trough east of Franz Josef Land, and becomes cooled by interaction with the atmosphere and freshened by mixing with low salinity shelf water. As it returns to the deep basin it has a reduced density, allowing it to enter between the PML and the Atlantic water.

The circulation of the upper layers, at least of the PML, was assumed similar to the ice drift, which is dominated by the anticyclonic Beaufort gyre centred in the Beaufort Sea in the southern Canada Basin and the Transpolar Drift extending from Siberia to Fram Strait (Fig. 6). The Atlantic water, by contrast, was deduced from the spatial variations of the temperature maximum in the
Atlantic layer to move cyclonically around the Arctic Ocean, entering through Fram Strait as the West Spitsbergen Current, circulating around the Arctic Ocean, and exiting through Fram Strait as the East Greenland Current (Timofeyev, 1962; Coachman and Barnes, 1963). It was assumed to lose its heat by turbulent diffusion to the overlying waters during its transit around the Arctic Ocean (Fig. 7).

In this context it is appropriate to mention the revolution the introduction of the CTD (conductivity-temperature-depth) made in providing details of the vertical stratification of the water column. It improved the resolution and showed features of the different water masses and offered clues to the active processes unobtainable before. One early example was the observation, made from the ice island T-3, of small regular steps at about $300 \mathrm{~m}$ depth in the thermocline above the Atlantic layer in the Canada Basin (Neal et al., 1969). The detection of these steps was facilitated by the stable platform provided by the sea ice, eliminating the surface wave motions. The alternating interfaces and homogenous layers (Fig. 8) indicated that the turbulent activity in the interior Arctic Ocean was low and that heat could be transported by molecular processes such as double-diffusive convection through the diffusive interfaces (Turner, 1973).

Observation from the AIDJEX pilot ice camps in the early 1970s and during the main AIDJEX experiment 1975-1976 showed the existence of several meso-scale eddies in the Canada Basin (Hunkins, 1974; Newton et al., 1974). Most of these eddies were anti-cyclonic, located in the upper $250 \mathrm{~m}$ of the water column and associated with waters with properties different from the surroundings. Only three of the eddies observed on the AIDJEX main 


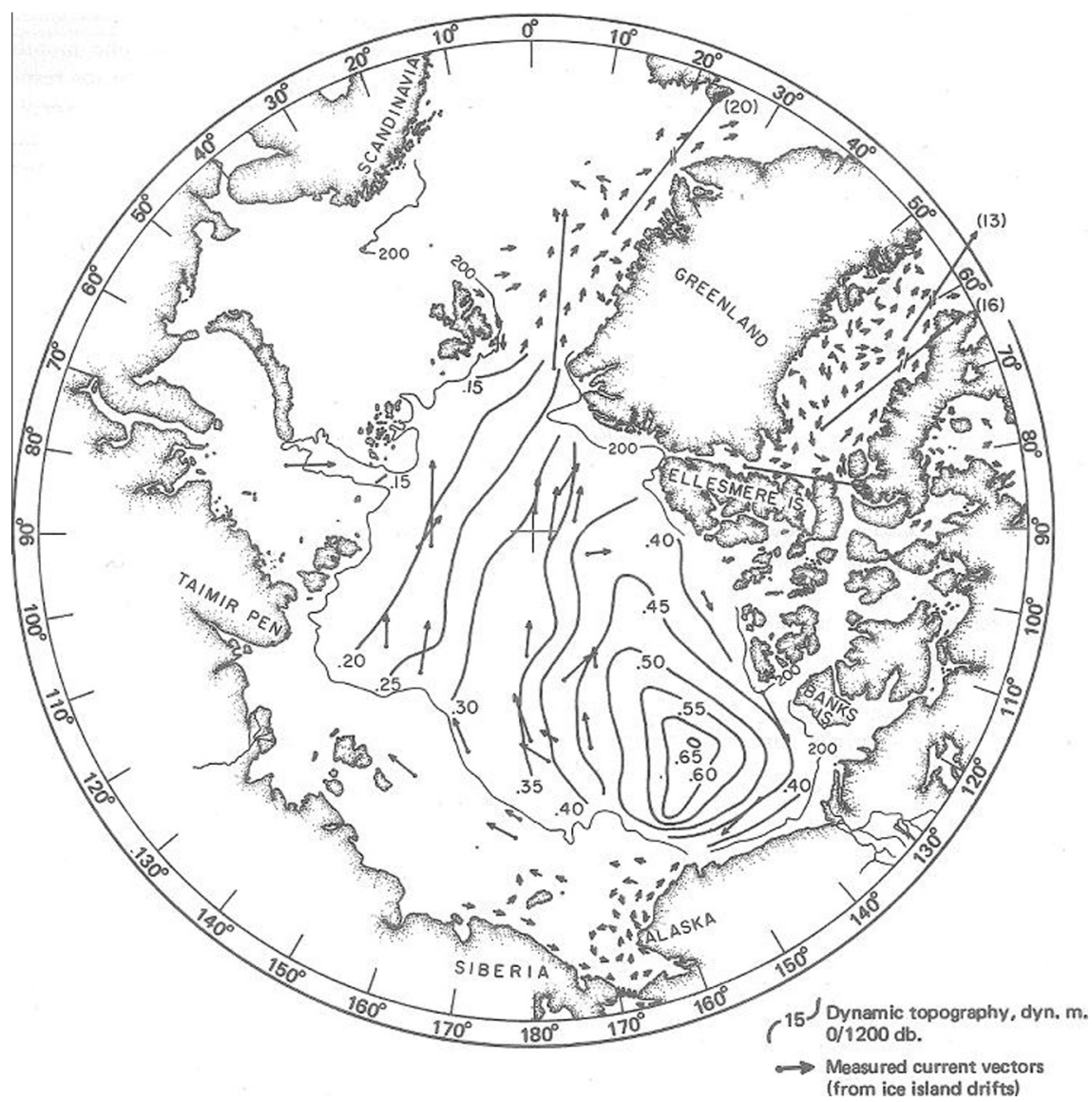

Fig. 6. Dynamic topography relative to $2000 \mathrm{db}$ (solid lines) and drift tracks from ice floes (arrows) (from Coachman and Aagaard (1974)).

camp were identified as cyclonic but two of these were found deeper than $500 \mathrm{~m}$, within or below the Atlantic layer (Manley and Hunkins, 1985). The depth range of the majority of the eddies coincides with that of the Pacific water, indicating that they are related to the inflow of Pacific summer and winter waters across the Chukchi Sea shelf. Hart and Killworth (1976) and Hunkins (1981) suggested that the eddies were formed by baroclinic instability as the Pacific water crosses the shelf break and Manley and Hunkins (1985) proposed a possible formation along the Alaskan shelf break. D'Asaro (1988a,b)also assumed that the eddies might be formed close to the Barrow Canyon but suggested that relative vorticity could be imparted to the entering water by friction against the coastal wall of the Barrow Canyon, creating the anti-cyclonic vorticity of the observed eddies.

The temperature of the deep water in the Amerasian Basin was found to correspond to that observed at $1300 \mathrm{~m}$ in the Eurasian Basin (Worthington, 1953). This fact was taken as evidence of the existence of a submarine ridge across the Arctic Ocean - the Lomonosov Ridge - which was discovered and charted by scientists from the Soviet Union at about the same time. The existence of a submarine ridge in the central Arctic Ocean had been deduced earlier from the characteristics of propagating tidal waves (Harris, 1911; Fjeldstad, 1936). This was also in agreement with Nansen's view that the deep water of the Arctic Ocean is formed in the Greenland Sea and then advected into the Arctic Ocean through Fram Strait (Nansen, 1915). The Lomonosov Ridge blocked the passage for the coldest and densest part of this inflow to the Amerasian Basin, which would instead be filled by water present at sill depth.

\subsubsection{Budgets}

The first detailed volume, heat and salt budgets for the Arctic Ocean and for the Nordic Seas were formulated during the 1960s and 1970s (Mosby, 1962; Vowinckel and Orvig, 1962, 1970; Timofeyev, 1963; Aagaard and Greisman, 1975). Prior to the 1950s the Arctic Mediterranean Sea, the part of the North Atlantic north of the Greenland-Scotland Ridge was considered an almost isolated sea and in the budget for the Arctic Mediterranean presented in "The Oceans" Sverdrup only considered transformations of Atlantic water into less dense and less saline Polar surface water. The northward transport through Bering Strait was assumed to be small, around $0.3 \mathrm{~Sv}\left(1 \mathrm{~Sv}=10^{6} \mathrm{~m}^{3} \mathrm{~s}^{-1}\right)$, and the transports through the Canadian Arctic Archipelago were regarded as negligible (Sverdrup et al., 1942). At that time the formation of North Atlantic Deep Water (NADW) was believed to occur in the North Atlantic south of Greenland and although contributions from dense overflows from the Arctic Mediterranean had been suggested in the past (e.g. Nansen, 1912), they were deemed not important.

The first budgets for the Arctic Ocean were based on volumes and salt balances and, when available, geostrophic calculations of the transports through the different openings. The transport of Atlantic water into the Arctic Ocean in the West Spitsbergen Current was determined by geostrophy from sections from Barentsburg on Svalbard to the ice edge to be 3-4 Sv (Timofeyev, 1963). A similar value was obtained by Fletcher (1965), while Mosby estimated an inflow of $1.4 \mathrm{~Sv}$. The outflow of low salinity Polar water in the East Greenland Current was estimated to $2 \mathrm{~Sv}$ by Mosby and $4 \mathrm{~Sv}$ by Fletcher, largely based on budget constraints and geostrophic computations. 

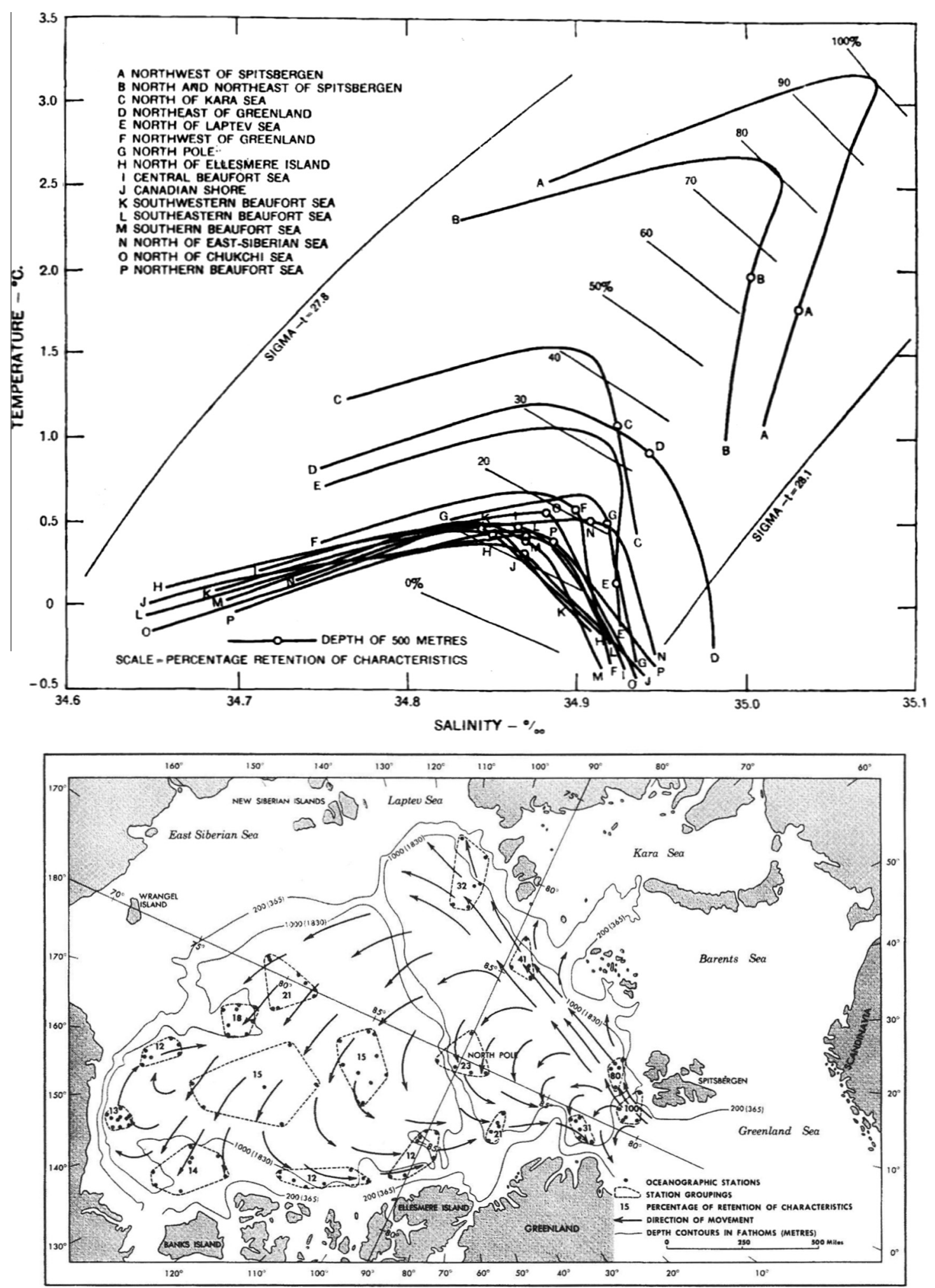

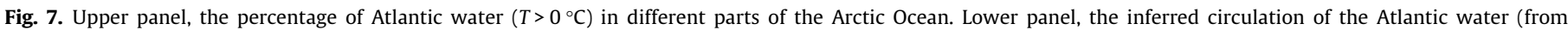
Coachman and Barnes, 1963).

The transports through the Canadian Arctic Archipelago were obtained by geostrophic computations in the individual straits as well as in Davis Strait between Baffin Bay and the Labrador Sea (Bailey, 1957; Collin and Dunbar, 1963; Muench, 1971). In Smith Sound and in the Nares Strait current observations were available that could supply estimates for the unknown reference velocity
(Day, 1968; Sadler, 1976). The overall transport through the Canadian Arctic Archipelago was estimated to 1-2 Sv.

The inflow through Bering Strait was found to be around $1 \mathrm{~Sv}$ from a one-dimensional hydraulic model of the strait, where the sea surface slope was balanced by bottom drag (Coachman and Aagaard, 1966). This agreed with existing current measurements in the Chuk- 


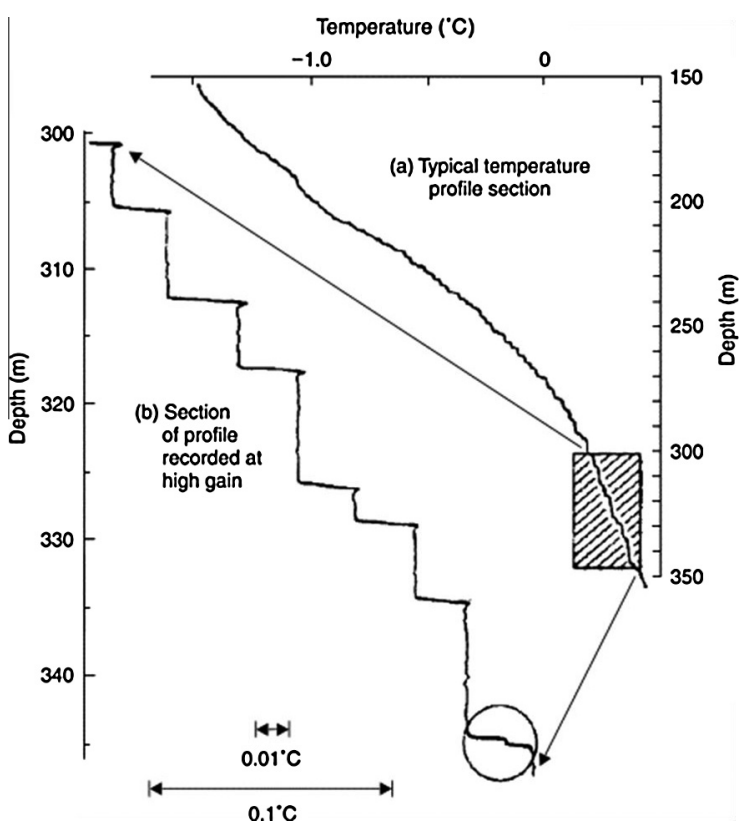

Fig. 8. Step structure in the thermocline above the Atlantic layer in the Canada Basin observed from the AIDJEX ice camp (from Neal et al., 1969).

chi Sea (Coachman and Aagaard, 1974). The most important contributions to the Arctic Ocean heat budget were the inflow of warm Atlantic water and the export of sea ice (latent heat) through Fram Strait.

The inflow through the Barents Sea was often neglected in the early budgets in spite of the fact that Petermann (1865) and also Nansen, before his expedition with Fram, considered this the most important passage of warm water from the North Atlantic into the Arctic Ocean (Nansen, 1902). In the budgets by Timofeyev (1963), Fletcher (1965) and Nikiferov and Shpaiker (1980) the inflow was estimated to about $1 \mathrm{~Sv}$, which was about one third of their estimated transport through Fram Strait. A later estimate by Aagaard and Greisman (1975) reduced this inflow to $0.7 \mathrm{~Sv}$.

The first direct yearlong current measurements were obtained in the West Spitsbergen Current in 1971-1972 (Aagaard et al., 1973). These indicated a much larger ( $>7 \mathrm{~Sv}$ ) northward transport of Atlantic water than found from geostrophic calculations. This showed that not all of the Atlantic water that enters the Arctic Ocean would be transformed into less dense Polar Surface Water and a substantial fraction of the Atlantic water had to return through Fram Strait as cooled "Arctic" Atlantic water in the East Greenland Current below the PSW. Aagaard and Greisman (1975) used the inflow estimated from the current measurements, 7.1 Sv, and postulated that the northward and southward transports in Fram Strait were equal. The outflow in the East Greenland Current was assumed to consist of $1.8 \mathrm{~Sv}$ of Polar water and 5.3 Sv of "Arctic" Atlantic water. The inflow through Fram Strait was then considered ten times larger than that over the Barents Sea.

The large transport of oceanic heat to the Arctic Ocean and the amount of heat stored in the Atlantic layer, enough to melt $20 \mathrm{~m}$ of sea ice, accentuated the question: If the river runoff should decrease, e.g. due to then discussed projects of turning one or two of the Siberian rivers southward for agricultural purposes, would this weaken the stratification sufficiently to allow heat from the Atlantic layer to be brought to the surface and reduce, and even remove, the ice cover (Aagaard and Coachman, 1975)?

\subsection{Activities and advances in the 1980s and early 1990 s}

The 1980s and 1990s saw the hesitant beginning of the ice breaker expeditions, first to the gateways and later into the interior of the Arctic Ocean. This largely improved the possibilities to make oceanographic observations, especially to collect water samples, being allowed to work on a ship instead of on the ice, either at an ice station or out of an airplane.

\subsubsection{Exchanges between the Arctic Ocean and the Nordic Seas}

The observational activity in the Fram Strait area increased significantly during the 1980 s, partly due to dedicated scientific icebreaker expeditions, starting with IB Ymer in 1980 and RV Polarstern in 1983, partly due to large international programmes like the Marginal Ice Zone Experiment (MIZEX), the Greenland Sea Project (GSP) and the Fram Strait Project (FSP), which brought additional capable ships into the area. MIZEX was primarily a process study concentrated on small and mesoscale motions in the vicinity of fronts, while the Fram Strait project investigated the exchanges between the Arctic Ocean and the Nordic Seas. Stronger ice breakers like Ymer and Polarstern and ice strengthened vessels like RV Lance made it possible to extend the sections across the entire strait onto the Greenland continental shelf and to the coast of Greenland. This resulted in better estimates of the outflow in the East Greenland Current and of the net exchanges through Fram Strait by geostrophic calculations combined with mass and salinity constraints (e.g. Rudels, 1987; Bourke et al., 1988).

In 1984-1985 yearlong moorings were deployed across the entire strait and a reduced number of moorings was also deployed in 1985-1986. The results from the current measurements (Foldvik et al., 1988) as well as from geostrophic calculations (Rudels, 1987; Bourke et al., 1988) and float observations (Quadfasel et al., 1987) showed that a large fraction of the Atlantic water of the West Spitsbergen Current recirculates in the strait and never enters the Arctic Ocean. The geostrophic calculations and also the moored current observations thus indicated a significantly lower transport of Atlantic water into the Arctic Ocean than those estimated from the current measurements in the 1970s. This suggested that the passage to the Arctic Ocean over the Barents Sea might be as important as Fram Strait for the mass balance of the Arctic Ocean (Rudels, 1987; Blindheim, 1989). The Barents Sea inflow, however, becomes cooled and freshened during its transit and does not contribute significantly to the oceanic heat transport to the Arctic Ocean.

\subsubsection{Water transformations in the Arctic Ocean}

In the 1980s the picture of an advection dominated, passive Arctic Ocean began to be revised. The formation of dense water on the shelves by freezing and brine rejection, earlier suggested by Nansen (1906), was proposed as a possible process for creating water dense enough to sink into the Arctic Ocean and penetrate between the Polar Mixed Layer and the Atlantic water and thus forming the halocline (Aagaard et al., 1981) (Fig. 9). Evidence that this process takes place was reported by Jones and Anderson (1986), who traced the nutrient maximum in the Amerasian Basin, observed around $150 \mathrm{~m}$ depth and centred on salinity 33.1 in the Pacific derived halocline, back to the Chukchi Sea and to the regeneration of nutrients from bottom sediments. Dense water, formed by freezing and brine rejection, sinks to and accumulates at the bottom during winter, where it becomes rich in dissolved nutrients. As it eventually crosses the shelf break and penetrates into the deep basins to its neutral density level it supplies the observed nutrient maximum.

Aagaard (1980) pointed out that the deep waters in the Amerasian Basin are not only warmer but also more saline than the deep waters of the Eurasian Basin, implying that the deep waters are transformed within the Arctic Ocean. The most probable mechanism also for such transformation is the creation of saline, dense water on the shelves, which then would sink down the slope into the deeper layers. Aagaard et al. (1985) and Rudels (1986a) developed circulation schemes for the deep waters of the Arctic Medi- 


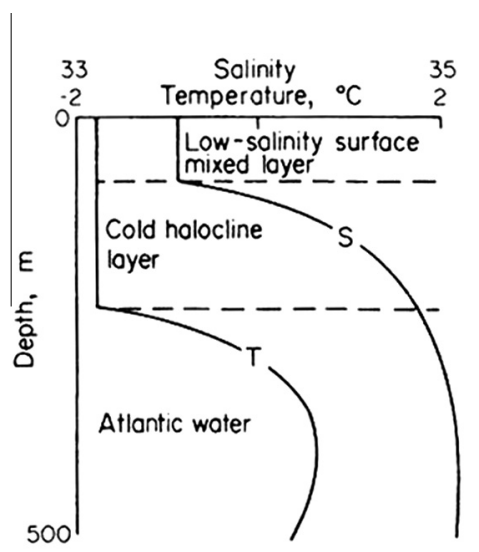

(a)

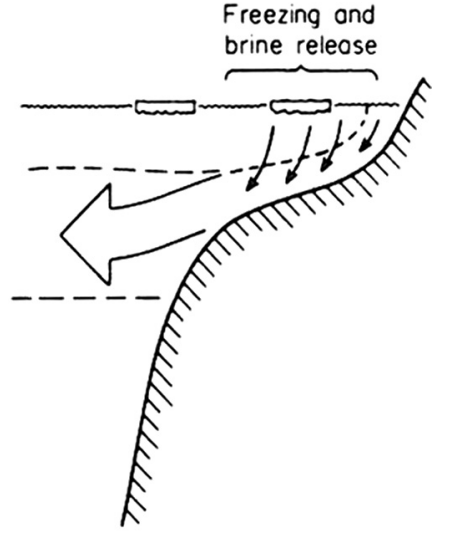

(b)

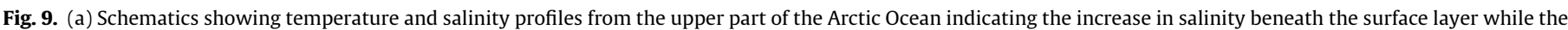

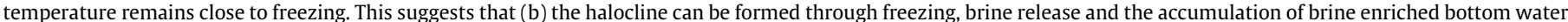

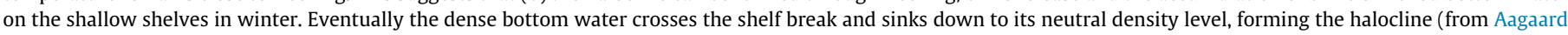
et al., 1981).
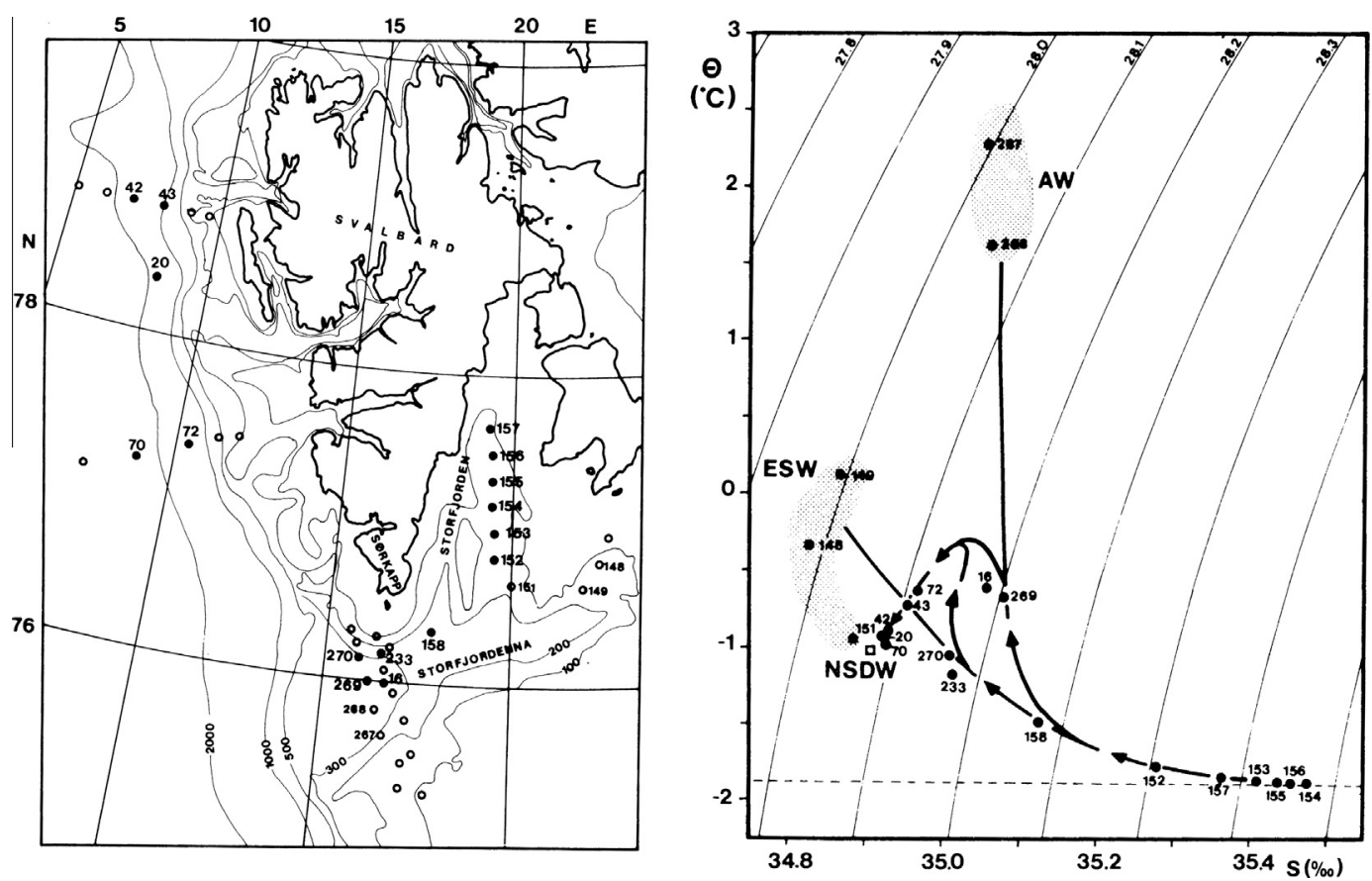

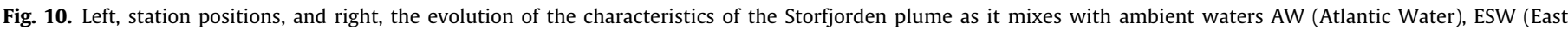
Spitsbergen Water), NSDW (Norwegian Sea Deep Water) (from Quadfasel et al., 1988).

terranean, connecting the dense, saline Arctic Ocean deep waters, formed by brine rejection on the shelves and slope convection and entrainment, with the less saline and colder Greenland Sea deep water, created by open ocean convection, by advection pathways through the Norwegian Sea and Fram Strait.

Two different plume concepts were proposed. Aagaard et al. (1985) introduced large shaving plumes, where the upper part of the plume becomes detached at different levels as the plume sinks down the slope, while Rudels (1986a) suggested several plumes, intermittent in time and space, which would sink through the water column, entraining ambient water until they reach their neutral density level and there merge with the surrounding water. Dense shelf water was reported from the Barents Sea west of Novaya Zemlya (Midttun, 1985) and from Storfjorden in the southern part of the Svalbard Archipelago (Anderson et al., 1988) and a dense, warm and more saline bottom layer, originating from Storfjorden, was observed in Fram Strait, substantiating the concept of entraining shelf-slope plumes (Quadfasel et al., 1988) (Fig. 10). The entrainment of warmer water would eventually make the more saline and denser plumes warmer than the ambient water, leading to both temperature and salinity increases in the deep waters that entered the Arctic Ocean from the Nordic Seas. The outflowing Arctic Ocean deep waters would then be recognised as saline cores in the deeper layers of the East Greenland Current (Aagaard et al., 1985; Rudels, 1986a). One upper, less dense core derives from the Amerasian Basin, and a deeper and colder salinity maximum originates from the Eurasian Basin (Rudels, 1986a).

\subsubsection{Circulation in the Arctic Ocean deep basins}

In 1991, on the Arctic Ocean-91 expedition, IB Oden and RV Polarstern reached, as the first conventional icebreakers, the North Pole after crossing the Eurasian basin and passing over the 

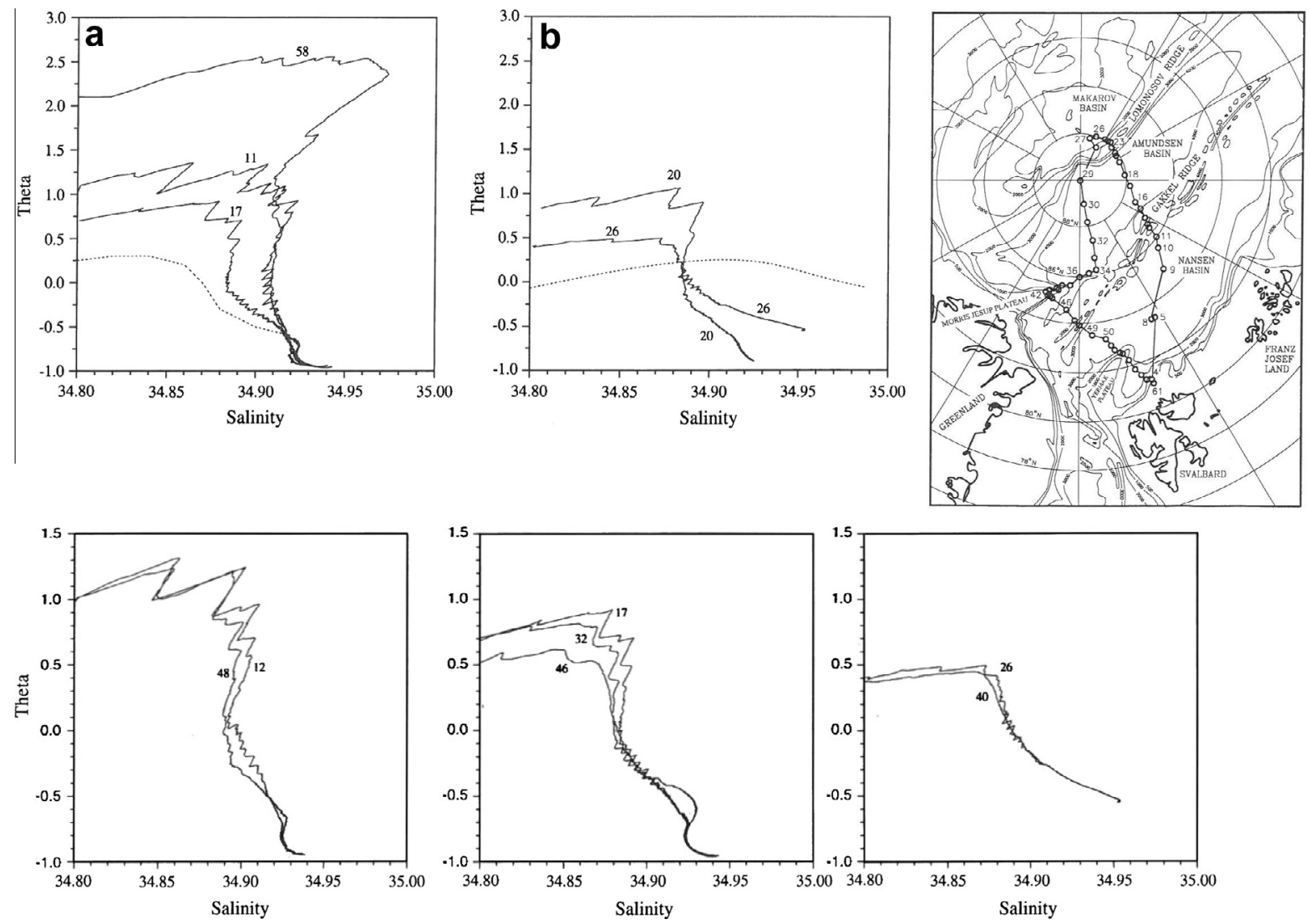

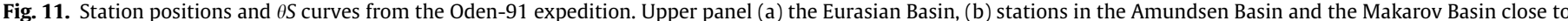

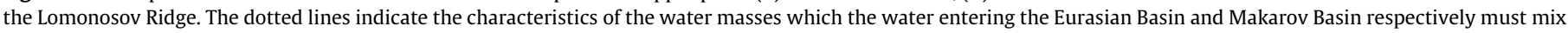

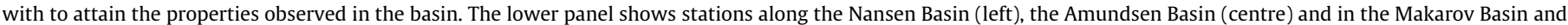
close to the Morris Jesup Plateau (right) displaying similarities in the intrusive features along the expected flow paths (from Rudels et al., 1994).

Lomonosov Ridge into the Makarov Basin. Although the station spacing in the Nansen Basin was sparse due to technical problems and time constraints sufficient information could be gathered from the water mass distribution to infer a more detailed circulation scheme for the Atlantic and intermediate layers. The temperature of the Atlantic core was decreasing from the Nansen Basin across the Gakkel Ridge, remaining fairly constant in the Amundsen Basin, and increasing slightly as the Lomonosov Ridge was approached. On the Makarov Basin side of the Lomonosov Ridge the temperature of the Atlantic layer decreased substantially. Over the Gakkel Ridge and in the Amundsen Basin interleaving structures were observed in the Atlantic layer between $250 \mathrm{~m}$ and $600 \mathrm{~m}$ as well as in the intermediate layer around $1000 \mathrm{~m}$. The salinities observed below the Atlantic layer in the Amundsen Basin and over the Gakkel Ridge were lower than those found in the Nansen Basin and in the Makarov Basin (Anderson et al., 1994; Rudels et al., 1994) (Fig. 11).

These observations were interpreted as results of interactions between two inflow branches. One branch enters through Fram Strait and then continues as a boundary current eastward along the continental slope. At the St. Anna Trough the boundary current encounters the second inflow branch, passing over the Barents Sea, which has become cooled and freshened by interactions with atmosphere and sea ice. Strong mixing between the two branches takes place, creating the interleaving layers observed in the interior of the Eurasian Basin. However, the colder end member, the Barents Sea branch, is in the interior of the basin found closer to the Lomonosov Ridge, suggesting that the two streams partly leave the continental slope and flow towards Fram Strait over the Gakkel Ridge, along the Amundsen Basin, and along the Lomonosov Ridge (Rudels et al., 1994).
The idea of a return flow along the Gakkel Ridge was not new. It was suggested by Anderson et al. (1989), using hydrographic and nutrient observations from the Polarstern 1987 cruise across the Nansen Basin, and by Quadfasel et al. (1993), based on XBT observations of intrusions over the Gakkel Ridge taken from the icebreaker Rossiya in 1990. Quadfasel et al. (1993) proposed that these intrusions were created by dense shelf water entering from the Laptev Sea and subsequently advected as fossil signals with the mean flow towards Fram Strait. Rudels et al. (1994) also assumed that the intrusions were mostly old, rundown and no longer active and advected with the mean flow. However, they suggested, because of the larger number of interleaving layers and the extensive depth range of the interleaving, that they originated from a more permanent source than an intermittent shelf outflow from the Laptev Sea. This left an inflow over the Barents Sea as the only remaining possibility.

This is different from the interpretation of the formation of thermohaline intrusions made by Perkin and Lewis (1984), who observed intrusive layers in the Nansen Basin north of the Barents Sea during the airborne EUBEX (Eurasian Basin Experiment) campaign. They considered that the intrusions were formed north of Svalbard as warm Atlantic water entered through Fram Strait and mixed with older Atlantic water present in the Nansen Basin. The detailed modelling of such a process was later elaborated by May and Kelley (1997, 2001).

Indications of a strong inflow from the Barents Sea, presumably via the St. Anna Trough, was found on the Polarstern cruise to the Laptev Sea in 1993 (Schauer et al., 1997). The Barents Sea branch enters the Arctic Ocean as a stratified water column, which follows the continental slope eastward as a colder, less saline $1000 \mathrm{~m}$ thick 
wedge that displaces the warmer, more saline Fram Strait branch farther into the basin and depresses the deeper underlying waters at the slope. The Barents Sea branch inflow in the St. Anna Trough and its interaction with the Fram Strait branch were further studied on Polarstern cruises in 1995 and 1996 (Rudels et al., 1999a, 2000a; Woodgate et al., 2001; Schauer et al., 2002a,b).

Rudels et al. (1999a) examined the interleaving structures observed on the Oden 1991 and Polarstern 1995 and 1996 cruises and suggested two mechanisms to explain the distribution of the interleaving layers in the Nansen and the Amundsen Basin: (1) The intrusions are driven by double-diffusive convection between the warmer Fram Strait branch in the Nansen Basin and the colder Barents Sea branch in the Amundsen Basin. (2) The intrusions are generated at the continental slope as the Barents Sea branch enters the Arctic Ocean in the St. Anna Trough and interacts with the Fram Strait branch. After a period of active double-diffusive convection and double-diffusively driven interleaving most of the potential energy initially available in the stratification is removed and the layers cease to be self-propelled. They are then advected with the mean circulation, first in the boundary current towards the Laptev Sea and then back along the Gakkel Ridge and the Amundsen Basin towards Fram Strait.

Barents Sea branch water was not only seen as colder intrusions in the Atlantic layer but also as a deeper, comparatively cold and less saline layer, occasionally creating a salinity minimum below the Atlantic water in the Amundsen Basin and over the Gakkel Ridge. This is different from the situation in the Makarov Basin side of the Lomonosov Ridge, where the temperature of the Atlantic layer was considerably lower but the intermediate water below was warmer and more saline than on the Amundsen Basin side (Fig. 11). This implies that the temperature and salinity in the intermediate layer have increased due to slope convection in the Amerasian Basin, presumably off the Chukchi Sea, and the more saline water circulates around the Amerasian Basin and enters the Makarov Basin from the North American side along the Lomonosov Ridge (Rudels et al., 1994). Differences in silicate concentrations in the Atlantic and intermediate water at the Oden stations close to the Morris Jesup Plateau indicated the presence of two separate streams north of Greenland. The colder one with higher silicate concentration was interpreted as having taken the longest loop along the continental slope around the entire Arctic Ocean. The slightly warmer water mass with less silicate content would then only have circulated in the Makarov Basin along the Alpha and Mendeleyev ridges and then again joined the boundary current north of Greenland (Rudels et al., 1994) (Fig. 12).

Warmer, more saline intermediate water in the Amerasian Basin is consistent with a simple mass balance model for entraining boundary plumes (Rudels et al., 1994). It is also obvious that the crossover to warmer and more saline intermediate water in the Makarov Basin compared to the Amundsen Basin occurs at levels shallower than the sill depth of the Lomonosov Ridge. This indicates that the higher temperatures and salinities in the Amerasian Basin intermediate water, the upper Polar Deep Water (uPDW), are due to a longer exposure to shelf-slope convection rather than to the blocking effect of the Lomonosov Ridge (Rudels, 1995; Meincke et al., 1997). The splitting of the boundary current at the Lomonosov Ridge was confirmed by direct current observations at the continental slope north of the Laptev and East Siberian seas and on the Amundsen Basin side of the Lomonosov Ridge (Woodgate et al., 2001).

A further insight, gained from the Oden-91 cruise, and previously also appreciated during the AIDJEX campaign (Mcphee, 1986), was that the limit of the local winter convection can be assessed by determining an upper temperature minimum associated with a fairly constant salinity, a halostad, both of which are

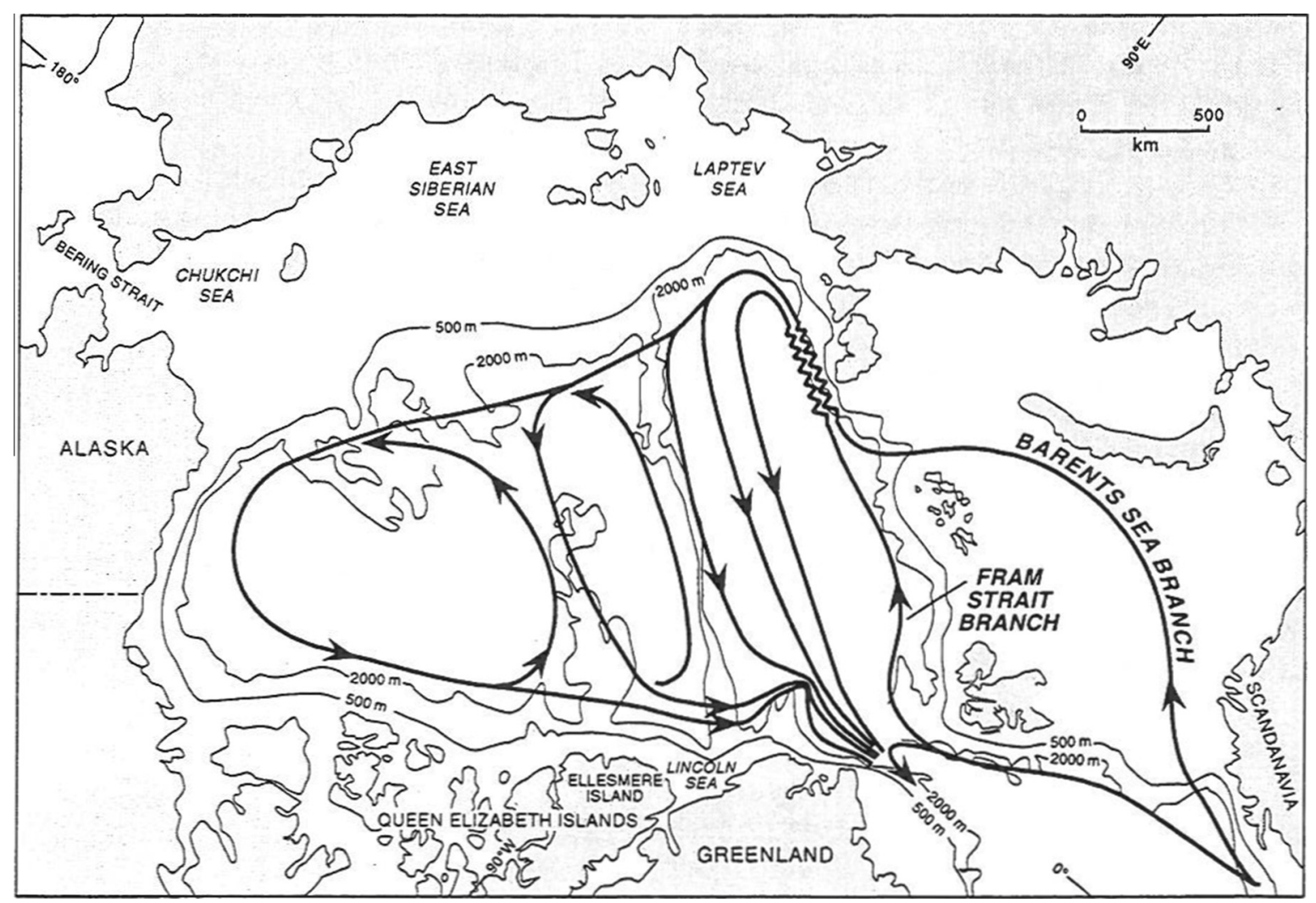

Fig. 12. The circulation of the Atlantic and intermediate waters inferred from the observed changes in $\theta S$ characteristics (from Rudels et al., 1994). 
gradually weakened by mixing from above and below during summer. Observations from the Nansen Basin showed that the temperature minimum was located deep, around $100 \mathrm{~m}$, and just above the thermocline. This implies that no permanent, cold halocline is present in the Nansen Basin, only a seasonal halocline formed by ice melt in summer and removed again by freezing during fall (Rudels et al., 1996).

The warm Atlantic water enters the Arctic Ocean and encounters and melts sea ice. Its upper part becomes transformed into a less saline layer, which in winter is homogenised first by cooling and thermal convection and eventually by brine rejection and haline convection. As the Fram Strait inflow moves farther into the Nansen Basin a seasonal halocline is developing in summer and then removed in fall and winter by brine rejection and haline convection reaching down to the thermocline. This situation holds for the entire southern part of the Nansen Basin as far east as the Laptev Sea, where the export of low salinity shelf water overruns the "winter mixed layer" and creates a salinity stratification in the upper part of the water column. The freezing and brine rejection in fall and winter cannot create water saline and dense enough to break through the increased stratification and reach the thermocline. The convection is limited to the less saline shelf water that is homogenised and becomes the Polar Mixed Layer (PML), while the initial deep winter mixed layer in the Nansen Basin becomes isolated from the sea surface and is gradually transformed into a halocline water mass. This halocline, created out of the upper part of the Fram Strait inflow branch, partly enters the Amerasian Basin, where it contributes to the "lower" halocline centred on a salinity of 34.3 (Rudels et al., 1996) (Fig. 13). This process of forming the halocline is an alternative to the brine rejection and accumulation of dense water on the shelves proposed by Aagaard et al. (1981). In the Nansen Basin the stratification above the Atlantic water is weak, and a shelf outflow is unlikely to penetrate between the upper layer and the Atlantic water. It would either enter at the surface or, being denser, sink directly into the Atlantic core or deeper.

\subsubsection{Double-diffusive interfaces}

The Arctic Internal Wave Experiment (AIWEX) showed that the interior Arctic Ocean was a low energy environment with little turbulence (Padman, 1995). This allows for small-scale processes such as double-diffusive convection, differential diffusion and effects of the non-linearity of the equation of state, contraction on mixing (or cabbeling) and the thermobaric effect to become important. Many of the processes active in ice covered waters and seas are described by Carmack (1986) and Padman (1995). During the AIWEX experiment 1985 conducted from the ice in the Canada Basin the diffusive interfaces and layers observed earlier from T3 (Neal et al., 1969; Neshyba et al., 1971) were intensively studied. It was found that the interfaces were a few $\mathrm{cm}$ thick and by assuming a diffusive flux through the interfaces coupled with a convection into and stirring of the layers the vertical heat flux could be estimated using laboratory flux laws (Padman and Dillon, 1987). The obtained heat transports were small, less than $0.1 \mathrm{~W} \mathrm{~m}^{-2}$, and it is unlikely that these transports can contribute significantly to the cooling of the Atlantic layer and still less to the oceanic heat flux to the upper layers and the sea ice.

\section{Change}

The increased number of icebreaker expeditions penetrating into the interior of the Arctic Ocean and the launching of the Scientific Submarine Expeditions (SCICEX) in the 1990s combined with the observations accumulated earlier during the century made it possible to move beyond establishing the mean conditions of the

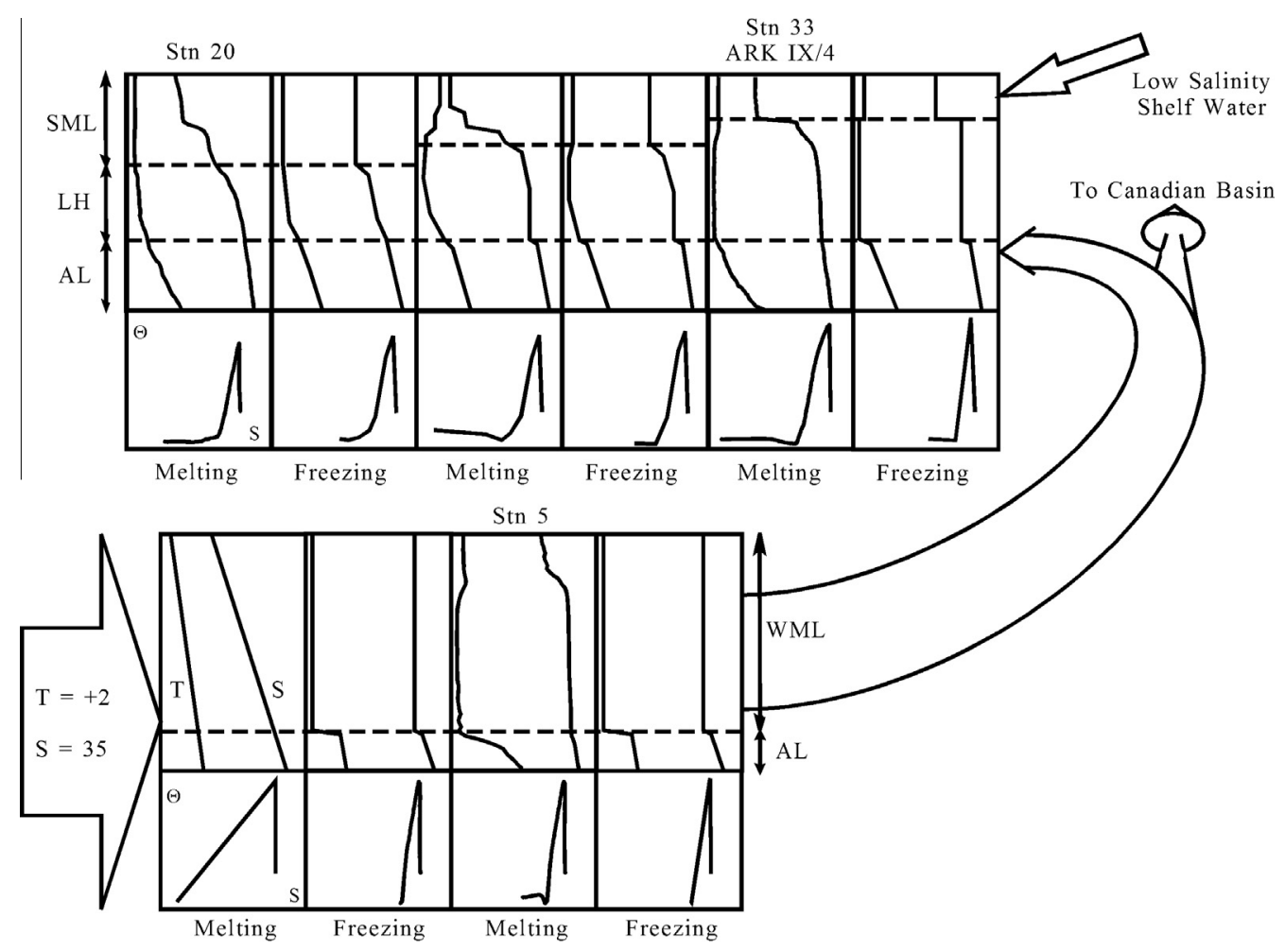

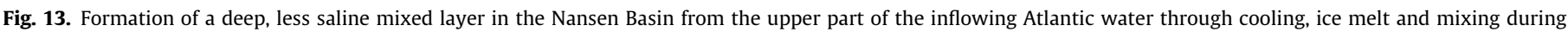

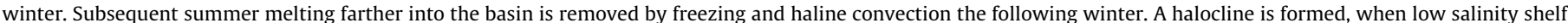

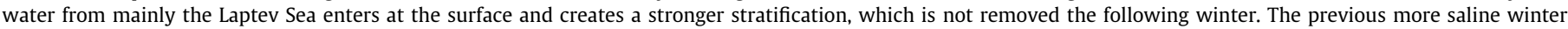
mixed layer is transformed into the more saline, "lower" halocline (from Rudels et al., 1996). 
Arctic Ocean hydrography to also detect changes in the properties of the water column and in the circulation.

\subsection{The Atlantic water}

The perhaps earliest indication of large changes in the Arctic Ocean came from the XBT observations made from the icebreaker Rossiya in 1990 (Quadfasel et al., 1991). It was discovered that the temperature of the Atlantic layer in the boundary current in the Nansen Basin was almost $1{ }^{\circ} \mathrm{C}$ higher than the long term mean. This temperature increase was traced to a warmer inflow in the West Spitsbergen Current during the late 1980s (Quadfasel et al., 1991, 1993; Grotefendt et al., 1998). This was not an isolated observation. In 1993 measurements from the Canadian icebreaker CCGS Henry Larsen indicated warmer Atlantic water in the Makarov Basin close to the Mendeleyev Ridge (Carmack et al., 1995). From the Henry Larsen observations it was also deduced that the boundary separating upper layer waters of Pacific origin from those of Atlantic origin had shifted from the Lomonosov Ridge to the Mendeleyev Ridge, allowing Atlantic derived waters to dominate the uppermost layers of the Makarov Basin (Carmack et al., 1995; McLaughlin et al., 1996).

The inflow of warmer Atlantic water in the Fram Strait branch persisted during most of the 1990s as was observed by the Polarstern cruises in 1993, 1995 and 1996 to the eastern part of the Eurasian Basin (e.g. Schauer et al., 1997, 2002a; Rudels et al., 2000a) and the temperatures in the Amundsen Basin and over the Gakkel Ridge were higher than those observed from Oden in 1991. A complete section across the Arctic Ocean from the Chukchi Sea to the Nansen Basin was obtained by the CCGS Louis S. St. Laurent during the Arctic Ocean Section (AOS) expedition 1994. This section showed a significant increase in Atlantic water temperature on the Amundsen Basin side of the Lomonosov Ridge as well as at the North Pole compared to 1991 (Carmack et al., 1997; Swift et al., 1997). The AOS-94 observations also confirmed the existence of the warm front penetrating into the Makarov Basin in 1993. In addition to tracking the advance of the temperature anomaly in the Atlantic layer, these observations proved valuable in testing the different circulation schemes proposed for the Atlantic water in the Arctic Ocean. Swift et al. (1997) estimated the time needed for the warmer Atlantic water to reach from Fram Strait along the continental slope to the Laptev Sea and then along the Lomonosov Ridge to the vicinity of the North Pole to about 10 years.

Some warm Atlantic water remained at the slope and crossed the Mendeleyev Ridge and entered the Canada Basin, but appeared to split as it approached the Chukchi Borderland. One part remained at the slope and moved between the Chukchi Sea and the Chukchi Borderland to the southern Canada Basin (McLaughlin et al., 2004; Shimada et al., 2004), while the rest flowed northward along the western flank of the Chukchi Borderland. This warm pulse could be followed to the northernmost part of the Chukchi Borderland, where it possibly splits into three parts. One part moves north, entering the Canada Basin. This loop was identified from tracer observations by Smith et al. (1999) and Smethie et al. (2000). The spreading of the other two branches were observed on the SHEBA/JOIS (Surface Heat Budget of the Arctic Ocean \& Joint Ocean Ice Studies) cruises in 1997-1998. SHEBA was conducted from the Canadian icebreaker CCGS Des Groseilliers, which was frozen into the ices for one year, acting as a drifting ice station. One branch turned southward following the eastern flank of the Northwind Ridge, possibly to join the boundary current at the slope, while the rest appeared to move eastward directly into the Beaufort Sea (McLaughlin et al., 2004; Shimada et al., 2004). The direct penetration was suggested to take place not by advection but through interleaving layers driven by double-diffusive convection (Walsh and Carmack, 2003; McLaughlin et al., 2009) but the velocities expected in the intrusions appear to be too small to explain the spreading (Shimada et al., 2004).

\subsection{The upper layers}

The Atlantic inflow during the 1990s was not only warmer than previously observed. The observations from the SCICEX cruise with the submarine USS Pargo in 1993 showed that the Atlantic layer in the Amundsen and Makarov basins had shifted to shallower levels, resulting in a salinity increase in the upper layer compared with historical data (Morison et al., 1998). By contrast the Atlantic layer was located deeper in the Canada Basin, leading to a lower salinity at similar levels in the southern Canada Basin (Fig. 14). At the North Pole the stratification above the Atlantic layer had weakened significantly after the Oden-91 expedition and the salinity gradient in the cold upper layers almost disappeared (Steele and Boyd, 1998). A similar situation was found in a large part of the Amundsen Basin and over the Gakkel Ridge (Schauer et al., 2002a) and also in the Makarov Basin (Steele and Boyd, 1998).

A likely cause for these changes would be that the low salinity shelf water, which "usually" crosses the shelf break in the eastern Laptev Sea and enters the Amundsen Basin, in the early and mid 1990s was diverted into the East Siberian Sea and then into the Canada Basin, largely bypassing the Amundsen and Makarov basins. This decrease in thickness of the low salinity upper layer brought the core of the Atlantic water closer to the surface. It also prevented the halocline to form over the Gakkel Ridge and in a large part of the Amundsen Basin, allowing for a homogenisation in winter down to the thermocline not only in the Nansen Basin, which does not normally receive any substantial amount of low salinity shelf water, but also in the Amundsen Basin and perhaps also in the Makarov Basin (Steele and Boyd, 1998) (Fig. 15).

This situation was described by Steele and Boyd (1998) as "the retreat of the cold halocline layer", but the creation of the water mass that eventually forms the cold, more saline layer between the PML and the Atlantic water did not stop. However, without the outflow of low salinity shelf water, capping the "winter mixed layer", no intermediate halocline layer was formed above the Atlantic layer. The "lower" halocline formation is then intimately tied to the discharge of low salinity shelf water to the interior of the Arctic Ocean. This in turn largely depends upon the state of the North Atlantic Oscillation (NAO) (Hurrell, 1995) and the Arctic Oscillation (AO) (Thompson and Wallace, 1998). The high, positive NAO situation shifts the mid-latitude cyclone tracks farther to the north, and they more often reach the Arctic Ocean over the Barents Sea and Fram Strait and weaken the high pressure cell over the Beaufort Sea. The anticyclonic circulation in the upper part of the gyre, mostly consisting of Pacific water, contracts and is forced towards the North American continent.

The effects of such a change in the atmospheric circulation were examined in a numerical model by Maslowski et al. (2000). They compared the situation in 1979 with that in 1993, when the Arctic Oscillation (AO) and North Atlantic Oscillation (NAO) were in high positive states. The ice drift changed from a strong and well established anti-cyclonic Beaufort gyre into an almost cyclonic circulation in the Beaufort Sea and the entering Pacific water was confined to the North American continent. The water from the Siberian rivers was deflected into the Amerasian Basin and the Atlantic water entering the Arctic Ocean over the Barents Sea and through Fram Strait, which with the 1979 atmospheric circulation had largely remained in the Eurasian Basin now crossed the Lomonosov Ridge and spread into the Makarov Basin. This is similar to the observed situation.

In recent years the conditions in the upper parts of the water column have been returning to "normal". The low salinity shelf water layer was re-established over the Lomonosov Ridge and over 

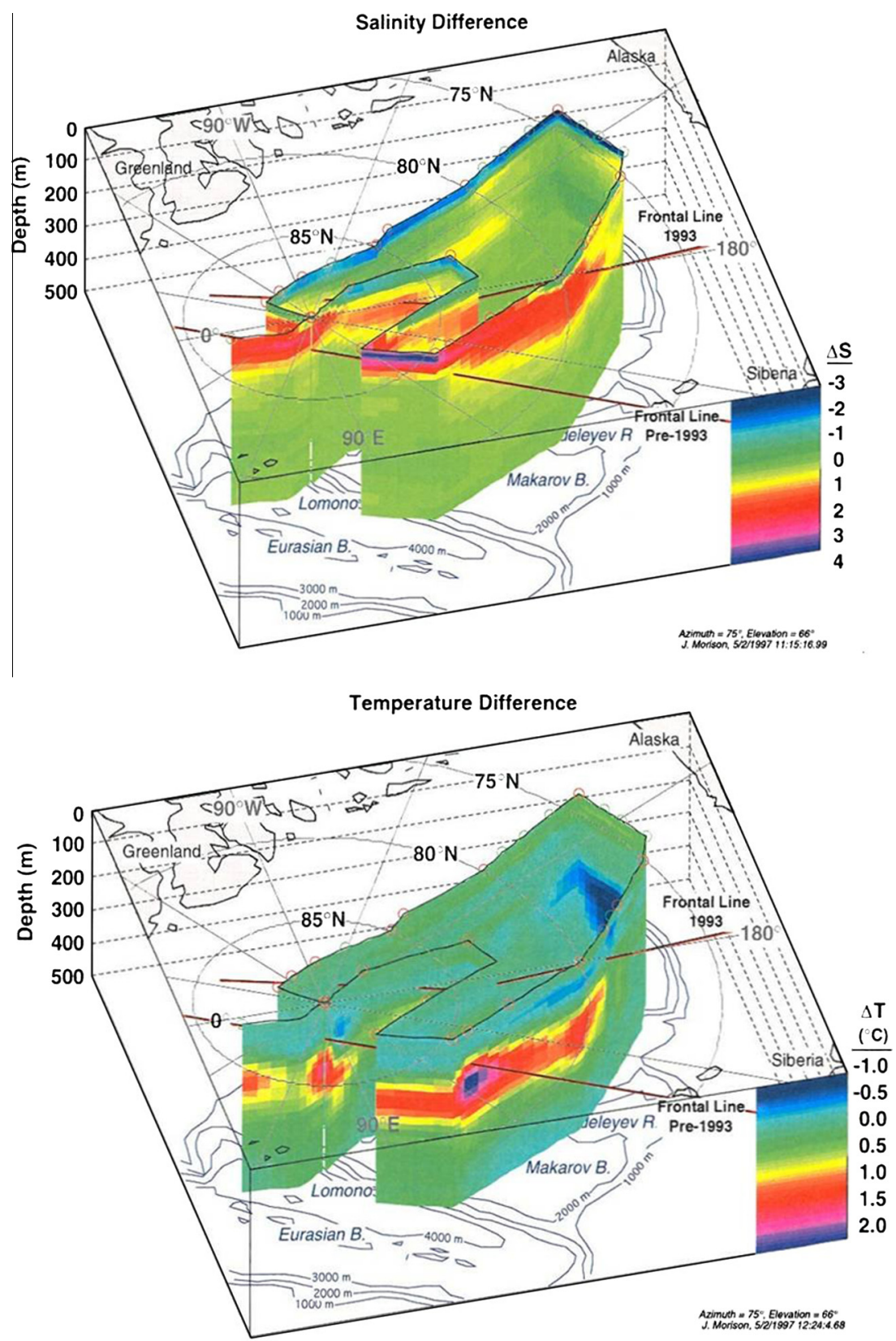

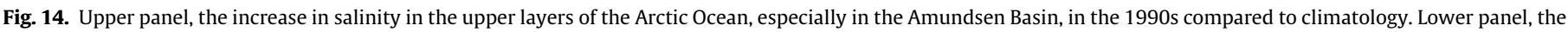

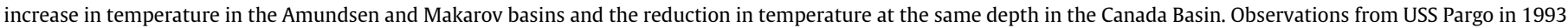
(from Morison et al., 1998).

much of the Amundsen Basin in 2001 (Björk et al., 2002; Boyd et al., 2002; Anderson et al., 2004). In 1997 a thick, more than $150 \mathrm{~m}$, saline upper layer with little shelf water was observed north of Fram Strait and Rudels et al. (2000b) suggested that this water derived from the high salinity upper layer observed in 1996 in the interior of the Eurasian Basin, which by then would have been advected to Fram Strait and was about to exit the Arctic Ocean.

\section{Variability, technical progress and the International Polar Year}

The large changes observed in the 1990s led to a search for similar strong events happening in the past, and the partial release of the Russian observations collected during the 20th century, especially the Environmental Working Group (EWG) data set, has opened the opportunity for studying the long-term variability of the Arctic Ocean (e.g. Polyakov et al., 2004; Swift et al., 2005). Swift et al. (2005) used a special version of the EWG data, which allowed for identification of different areas and examined the variability in the upper layer, the Atlantic layer and the Pacific waters. Similar strong and sudden changes as in the 1990s could be detected in the 1960s, which showed a strong increase in Atlantic water temperatures and in the 1970s with a salinity increase in the upper layer. The weakening and disappearance of the Pacific water Silicate maximum in the central Arctic Ocean was found to occur in the mid 1980s, before the inflow of warm Atlantic water and the redistribution of the low salinity shelf water into the Amerasian Basin in the 1990s. The causes behind the observed variability could, however, not be determined with certainty. 


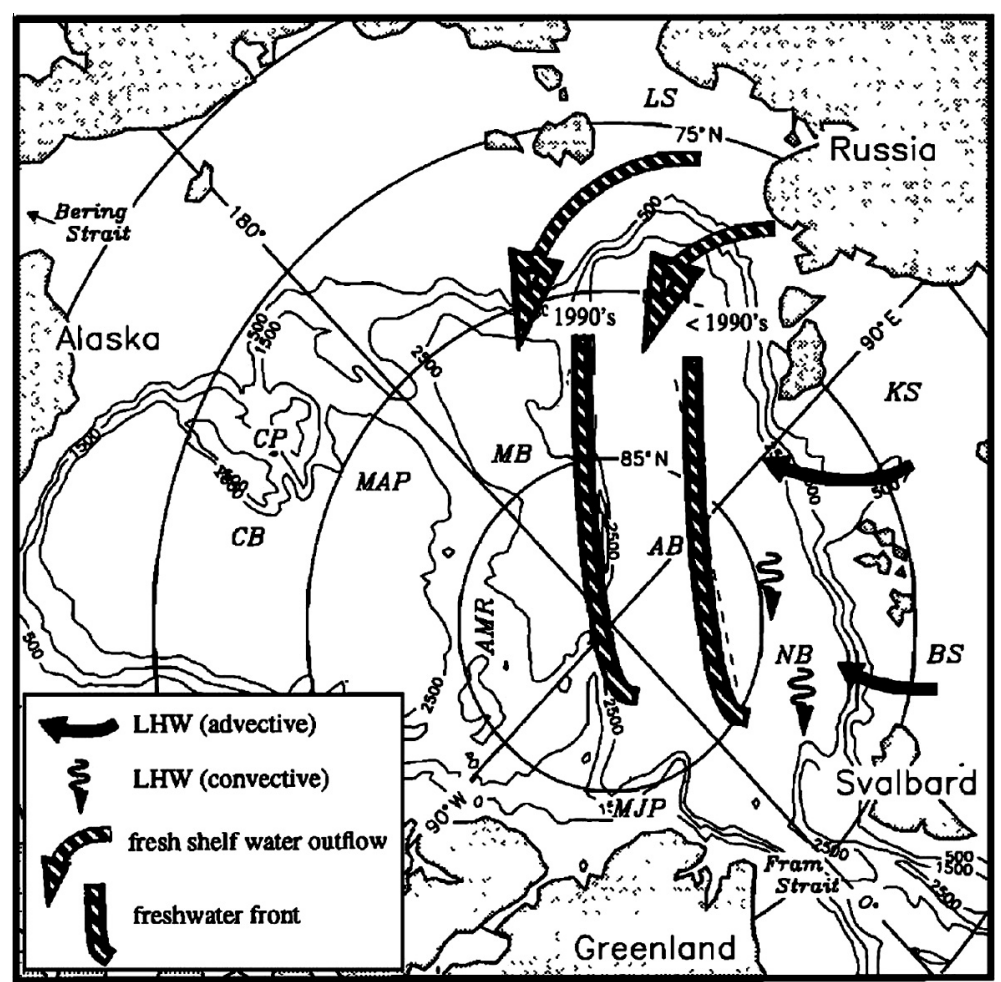

Fig. 15. The shift in the freshwater front and the changes in the outflow paths of the low salinity shelf water during the 1990s (from Steele and Boyd, 1998).

To study the variability in the interior of the Arctic Ocean time series are necessary, obtained either by repeated ship observations or by moored instruments. Before the 1990s long-term current deployments in the deep Arctic Ocean basin, at the rim and in the interior, were almost non-existent (Aagaard, 1989). The three current meters on the Laptev Sea and the East Siberian Sea slopes and on the Amundsen Basin side of the Lomonosov Ridge at the $1700 \mathrm{~m}$ isobath deployed and recovered from Polarstern in 1995-1996 thus constitute one of the first long (one year) current meter deployment in the interior of the Arctic Ocean (Woodgate et al., 2001). In the first decade of the 21st century many more long-term mooring deployments have been undertaken. The Nansen Amundsen Basin Observation System (NABOS) was established at the Laptev Sea continental slope in 2002. The North Pole Environmental Observatory (NPEO), consisting of one deep mooring in the Amundsen Basin close to the North Pole, was established in 2001 (Morison et al., 2002). The Beaufort Gyre Exploration Program (BGEP) started with four deep moorings in the Beaufort Sea in 2003 (Proshutinsky et al., 2009). Within the Shelf-Basin Interaction initiative (SBI) a current meter and CTD mooring array was established 2002-2004 across the Alaskan shelf and slope (Spall et al., 2008; Nikolopoulos et al., 2009). The mooring array was later replaced by a single mooring. These efforts allowed for a more intense study of the Arctic Ocean variability.

In 2004 the first Ice-Tethered Profilers (ITP) were deployed. These instruments, consisting of a profiling ctd and a transmitter at the surface that sends its data via satellite to the home laboratory, have given a possibility for real-time monitoring of the water column (Krishfield et al., 2008; Toole et al., 2011). Although subject to wind and ice motion the ITPs have, by virtue of the often slow drift and the short time between the profiles, been suitable not only for studying seasonal changes but also small-scale features such as eddies as well as diffusive interfaces and layers and thermohaline intrusions (Toole et al., 2011).

The fourth International Polar Year (IPY) was launched 20072009. This counting includes the Geophysical year 1957-1958.
The IPY was in all respect a success. It gave Polar sciences a presence in a much wider community than was expected. Nature itself also played along by creating, in 2007, the smallest minimum ice cover extent ever observed, which brought the Arctic conditions and its relation to the global climate and to climate change into focus. It is not possible here to review all research undertaken during IPY and continued after 2009. A comprehensive overview of the Arctic activities is given in a special number of Oceanography, "the Changing Arctic Ocean" (Ortiz et al., 2011), and the development of the Arctic Ocean Observations is clearly presented in the iAOOS (intergrated Arctic Ocean Observing System) reports by Dickson $(2008,2009,2011)$ and Dickson and Fahrbach (2010). Here results from IPY will not be especially highlighted, but given their proper place in the growing knowledge of the Arctic Ocean and the processes determining its state and evolution.

\subsection{The Atlantic water}

\subsubsection{The Fram Strait inflow Branch}

The extended inflow pulse of warm Atlantic water apparently ceased during the 1990s. The temperature of the Atlantic water in Fram Strait was lower in 1997 than in the mid 1980s (Rudels et al., 2000b), and north of the Laptev Sea the temperature of the Atlantic water observed on the NABOS cruise in 2002 was reduced considerably from the high values observed by Polarstern in 1993, 1995 and 1996 (Dmitrenko et al., 2005, 2008a; Polyakov et al., 2005). In the Eurasian Basin similar interleaving structures were identified in the warm Atlantic layer over the Gakkel Ridge. In 1995 they were seen north of the Laptev Sea, in 1996 in the central part of the Eurasian Basin, and in 1997 northwest of the Yermak Plateau. This was interpreted as a return flow within the Eurasian Basin of the warm Atlantic water pulse that had entered through Fram Strait in the mid and late 1980s (Rudels et al., 2000b).

The downstream propagation of the part of the earlier pulse that crossed the Lomonosov Ridge had by 2005 reached to the southern Canada Basin, but the penetration of the warm Atlantic 


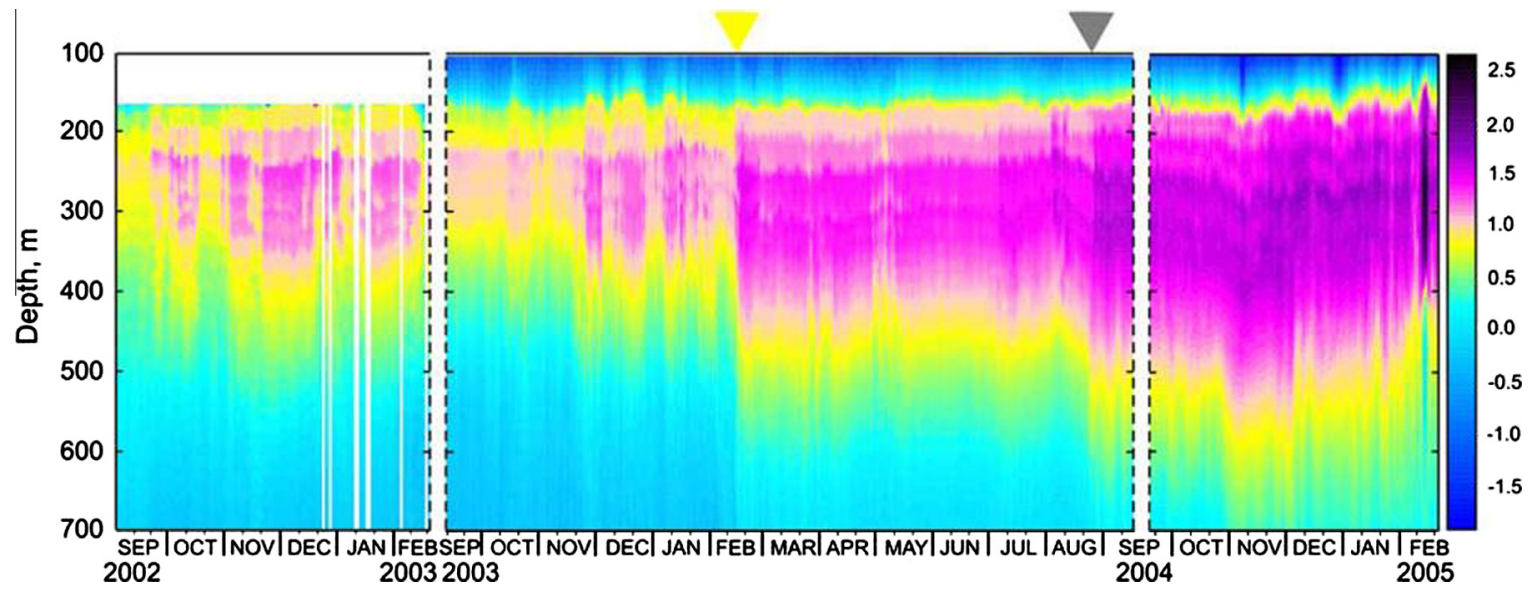

Fig. 16. The sudden increase in Atlantic water temperature observed at the NABOS moorings north of the Laptev Sea in 2004 (from Dmitrenko et al., 2008a).

pulse into the southern Canada Basin and the Beaufort gyre appears to be slow and either take place in the boundary current along the continental slope or moving directly into the Beaufort gyre from the Northwind Ridge (Shimada et al., 2004). This direct spreading into the interior of the Beaufort gyre has been suggested due to the penetration of thermohaline intrusions from the boundary current into the centre of the gyre (Walsh and Carmack, 2003; McLaughlin et al., 2009). McLaughlin et al. (2009) also proposed that the interior path might be driven by an anti-cyclonal circulation of the Atlantic layer in the Beaufort gyre. Such anti-cyclonic circulation had been deduced earlier by Coachman and Barnes (1962) and by Newton and Coachman (1974) and could be especially well developed when the atmospheric forcing of the Beaufort gyre leads to strong Ekman pumping, accumulating upper layer water in the centre of the gyre, which has been the case in the late part of the 2000s. The presence of a colder Atlantic layer at the Alpha Ridge also suggests that older Canada Basin Atlantic water has been forced towards the Alpha Ridge and is partly recirculating in the Canada Basin (Falkner et al., 2005).

In the Makarov Basin the temperature of the Atlantic layer had increased throughout the basin since the early 1990s, indicating that the warm Atlantic water reported by Carmack et al. (1995) had circulated around the basin, reaching the North Atlantic continental slope east of the Alpha Ridge, and was 10 years later partly returning towards Siberia along the Lomonosov Ridge (Kikuchi et al., 2005). On the Amundsen Basin side of the Lomonosov Ridge the temperature, by contrast, had decreased, consistent with a bifurcation of the boundary current at the Lomonosov Ridge and that the colder water observed north of the Laptev Sea in 2002 was propagating towards Greenland along the Lomonosov Ridge.

The temperature measured at the NABOS moorings on the Laptev Sea slope began to rise again in 2004, when a sudden increase in both temperature and thickness of the Atlantic layer was observed, occurring almost over a day (Fig. 16). The temperature has remained high thereafter (Dmitrenko et al., 2008a,b; Polyakov et al., 2005). A corresponding temperature and salinity increase was seen in Fram Strait a few years earlier, starting in 1998, indicating the arrival of a new pulse of warm Atlantic water at Fram Strait to enter the Arctic Ocean (Schauer et al., 2004, 2008; Fahrbach, 2006). A further increase in temperature and salinity in Fram Strait occurred between 2002 and 2004, reaching its maximum in 2006 (Beszczynska-Möller et al., 2012) indicating a new warm pulse on its way into the Arctic Ocean. The advection of these pulses around the basins has been documented by Polyakov et al. (2010, 2011, 2012a), who also discuss their possible impact on the Arctic Ocean ice cover and climate. The pathways of these pulses have been modelled e.g. by Karcher et al. (2011), describing the different loops in the Arctic Ocean basins.

In addition to these warm water pulses there are seasonal changes in the temperature observed in the boundary current due to the different atmospheric circulations dominating in winter and summer (see e.g. Fig. 27 below). This brings the Atlantic water closer to the surface in winter, thus indicating a higher temperature at a given level (Dmitrenko et al., 2006). There are also the seasonal variations of the Fram Strait inflow temperatures, which do not disappear as the Atlantic water enters the Arctic Ocean. Instead they are advected along in the boundary current, adding seasonal variability to downstream observations in the boundary current, the phase depending on the distance from Fram Strait. The seasonal signal is present east of Svalbard (Ivanov et al., 2009) and from the model and observational study by Lique and Steele (2012) the seasonal signal, receiving additional input from the Barents Sea branch inflow in St. Anna Trough, should still be detectable north of the Laptev Sea with a phase lag of one year. This suggests a rather rapid, $0.06 \mathrm{~ms}^{-1}$, flow along the Eurasian continental slope.

\subsubsection{The Barents Sea branch}

Less saline and colder water was observed below the Atlantic layer in the Makarov Basin from the CCCG Henry Larsen in 1993. It was proposed by McLaughlin et al. (1996) that this water was produced on a nearby shelf, presumably the East Siberian Sea shelf. Similarly, during the AOS-94 expedition with the CCGS Louis S. St-Laurent a colder and less saline lens was observed in the deeper $(1000 \mathrm{~m})$ part of the water column in the Makarov Basin close to the Mendeleyev Ridge (Fig. 17). The lens was also first assumed connected with dense outflows from nearby shelves (Aagaard et al., 1996; Carmack et al., 1997), but was later identified as similar to the denser water from the Barents Sea branch that penetrates beneath the warm core of the Fram Strait branch (Swift et al., 1997). The intermediate water in the Makarov Basin is clearly colder and fresher than the intermediate water in the Canada Basin (Fig. 17), and observations at the sill of the Lomonosov Ridge close to the Siberian shelf showed water of similar characteristics on both sides of the Lomonosov Ridge (Rudels et al., 2000a) (Fig. 18).

This was perhaps one of the first times an eddy was observed so deep in the water column in the Arctic Ocean. Eddies had been detected previously, especially in the Canada Basin in the upper 100-200 m (see Section 2.3.1 above). In 1996 several deep eddies were observed in the Eurasian Basin from Polarstern (Schauer et al., 2002a) (Fig. 19). After this, deep eddies have been found to be fairly common in the Arctic Ocean (Aagaard et al., 2008; Walsh 

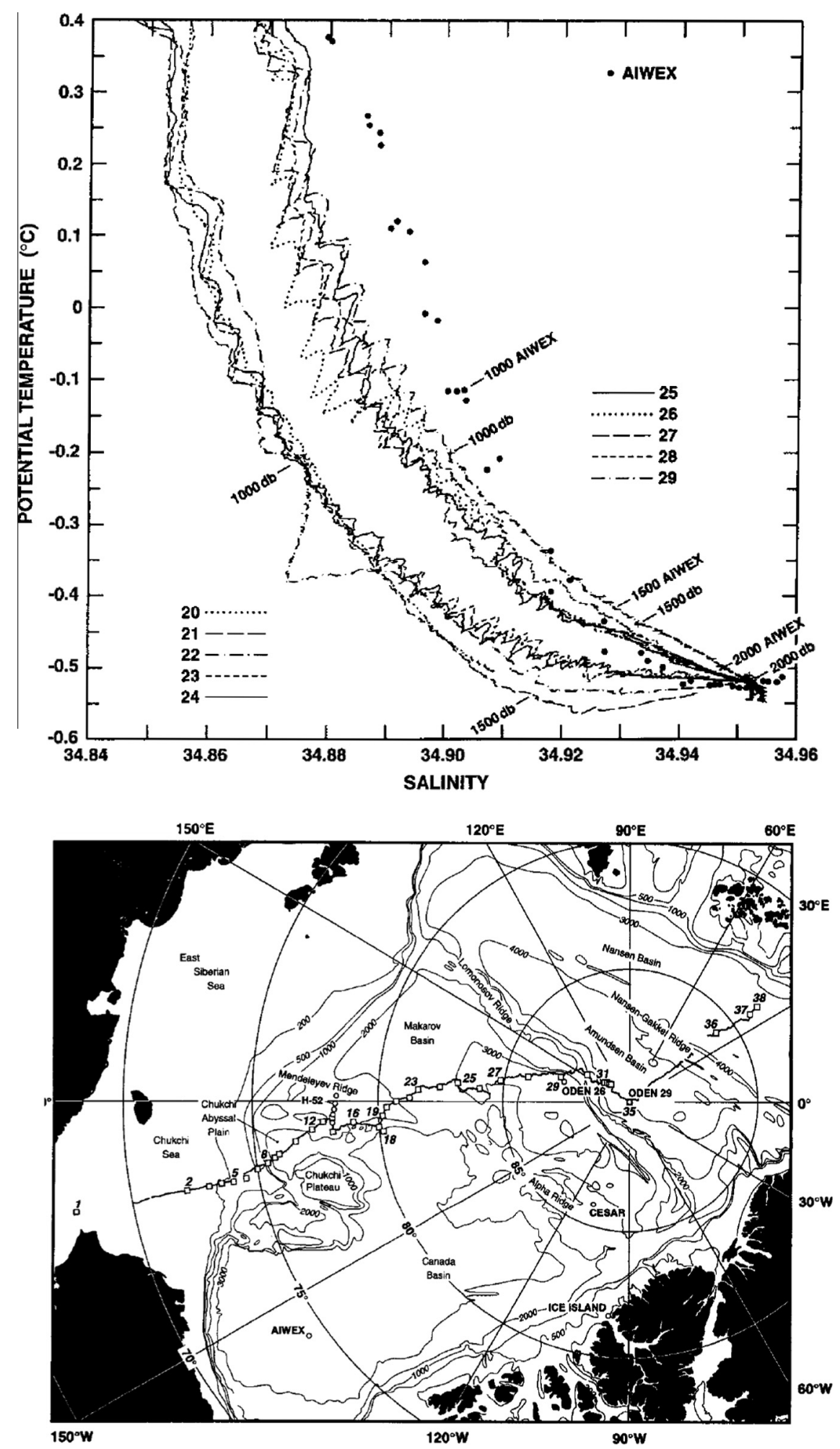

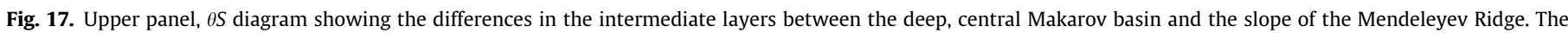
deep, cold and low salinity eddy is located at station 22. The station positions are shown in the lower panel (from Swift et al., 1997).

et al., 2007; Dmitrenko et al., 2008b; Carpenter and Timmermans, 2012).

In the Eurasian Basin the intrusion of the Barents Sea branch decreases the temperature and salinity of the water column below the Atlantic layer, bending the $\theta S$ curves in the intermediate water density range below the straight line towards lower temperatures and higher salinities. In the Amerasian Basin, by contrast, the intermediate layer below the Atlantic layer but above the sill depth of the Lomonosov Ridge is characterised by temperatures decreasing from $0{ }^{\circ} \mathrm{C}$ to $-0.5^{\circ} \mathrm{C}$ and salinities increasing with depth, forming an almost straight line in the $\theta S$ curves (Fig. 20). As the boundary current crosses the Lomonosov Ridge the colder, less saline $\theta S$ 


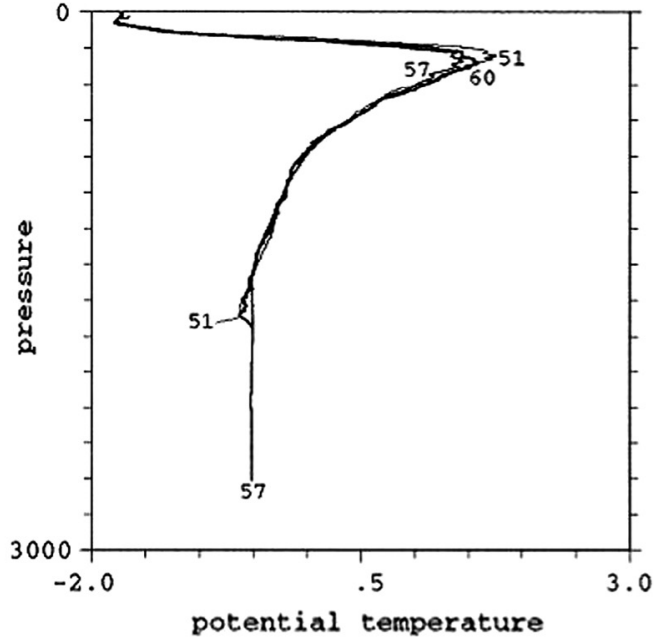

(a)

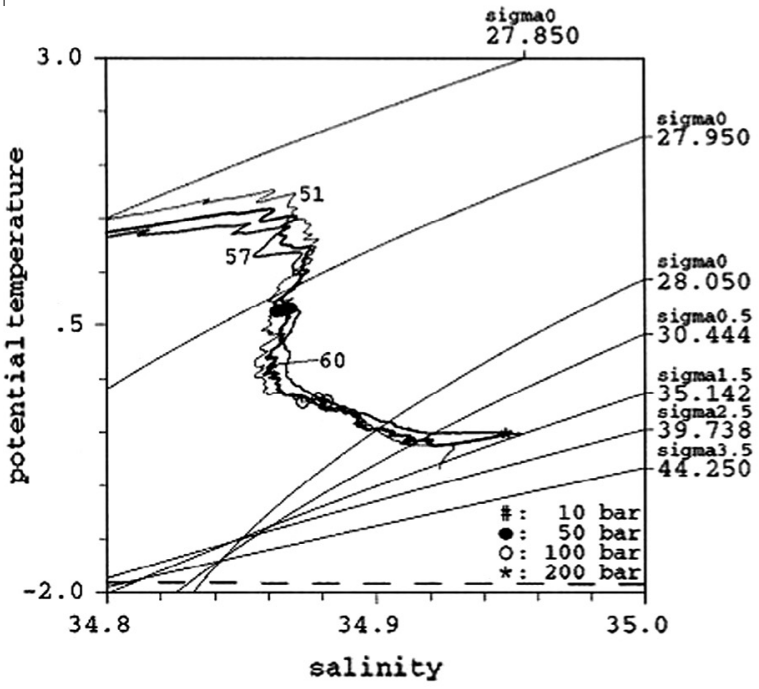

(c)

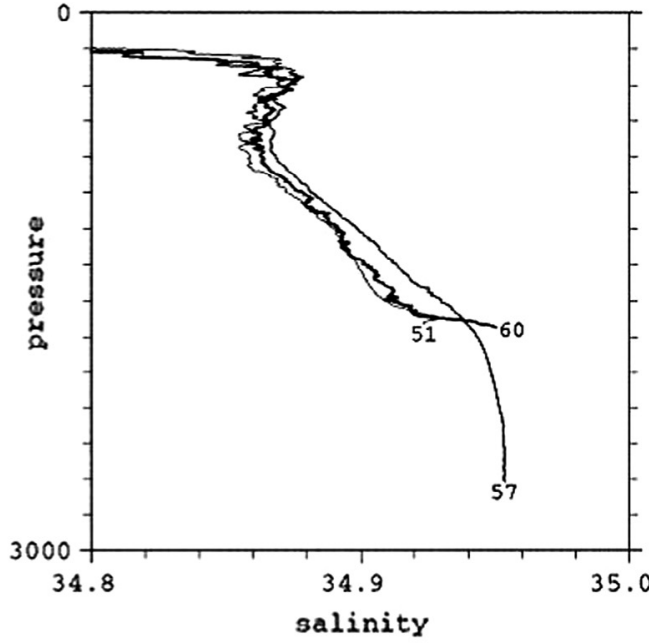

(b)

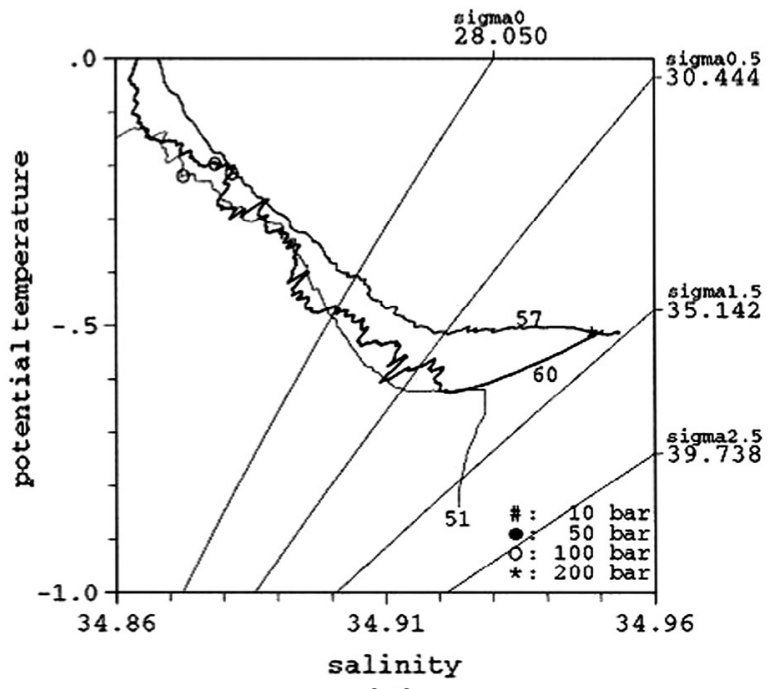

(d)

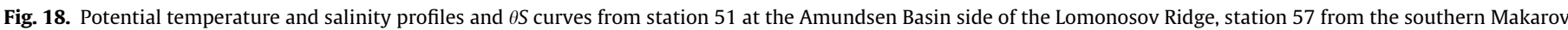

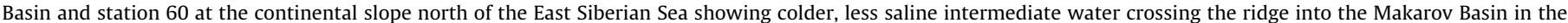

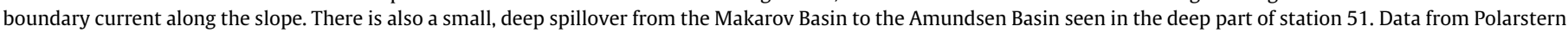
1995 (from Rudels et al., 2000a).

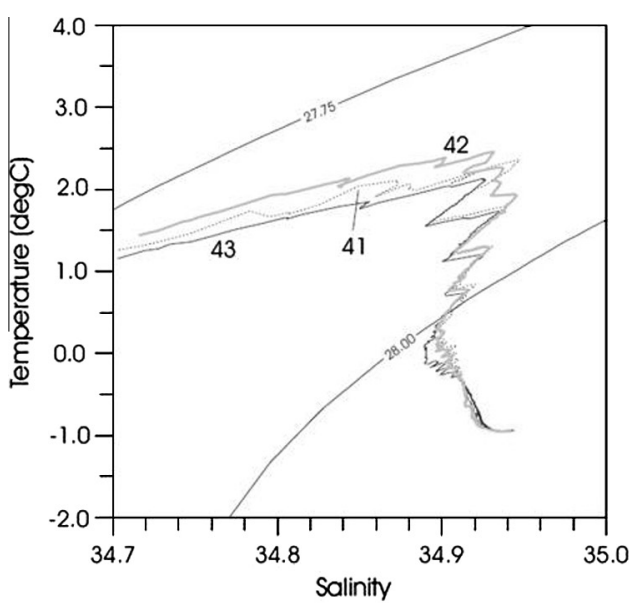

(a)

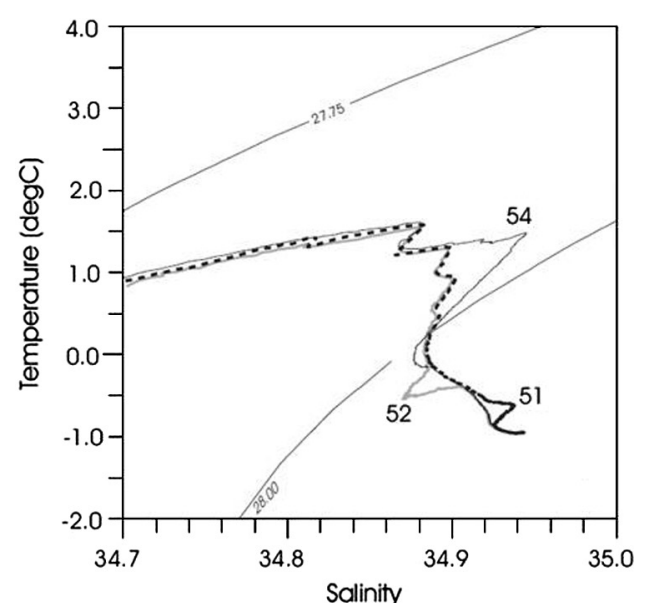

(b)

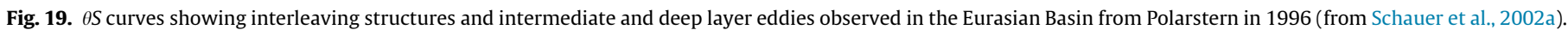




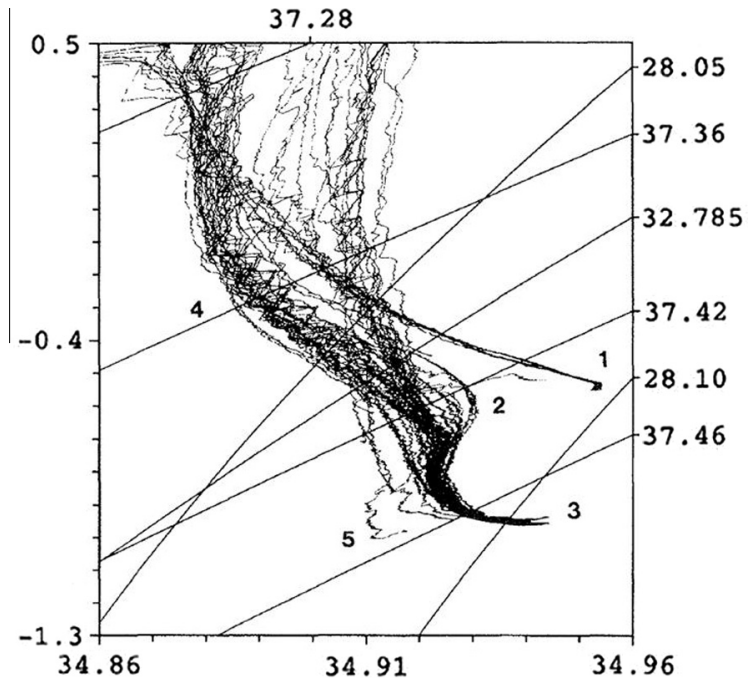

Fig. 20. $\theta S$ curves from the Oden 91 stations showing (1) the intermediate and deep waters in the Makarov Basin with the almost linear increase in salinity and decrease in temperature with depth in the intermediate layer and the decrease in temperature at constant salinity in the bottom water. (2) indicates the salinity maximum in the Amundsen Basin created by Makarov Basin deep water that has crossed the Lomonosov Ridge. (3) shows the increase in salinity with depth in the bottom water of the Amundsen and Nansen basins. The slight increase in temperature is also seen. (4) indicates the less saline intermediate water of the Amundsen Basin deriving from the Barents Sea inflow branch. (5) shows the less saline and colder Nordic Sea Deep Water north of the Yermak Plateau that has entered through Fram Strait (from Rudels, 1995).

structure is advected into the Amerasian Basin (Rudels et al., 2000a) and penetrates into the Makarov Basin as was seen on the AOS-94 stations taken close to the Mendeleyev Ridge (Swift et al., 1997). Because of the higher temperature of the deep water in the Makarov Basin than in the Eurasian Basin the Barents Sea branch intermediate water with $\theta<0{ }^{\circ} \mathrm{C}$ and $S<34.90$ here shows up as a temperature minimum. This advection of colder, less saline water could indicate a gradual change occurring in the intermediate layer of the Amerasian Basin. Another possibility is that the slope convection in the Amerasian Basin, especially at the Chukchi Sea slope, transports cold, saline water produced in lee polynyas on the shelves (Aagaard et al., 1985; Winsor and Björk, 2000) and by entrainment redistributes heat downwards within the water column, changing the initial $\theta S$ structure of the entering boundary current into the straight, warmer and more saline curves found in the Amerasian Basin (Rudels et al., 1994, 2000a; Rudels and Friedrich, 2000).

Not just the Fram Strait branch changed its characteristics during the 1990s. Between the Oden 1991 section and the Polarstern sections taken closer to the Laptev Sea in 1995-1996 the salinity of the Barents Sea branch intermediate water $\left(\theta<0{ }^{\circ} \mathrm{C}\right)$ had decreased and not just a bent $\theta-S$ curve but also a salinity minimum was present below the Atlantic layer (Fig. 18). Since the Fram Strait inflow during this period was warm and saline the changes must have taken place in the Barents Sea, where they could be caused by increased cooling and precipitation. Another possibility would be that sea ice drifts into the Barents Sea and melts, creating less saline upper layer water, which in winter becomes dense enough to convect into and freshen the main part of the Barents Sea inflow (Rudels and Friedrich, 2000; Aagaard and Woodgate, 2001). Rudels and Friedrich (2000) explored the possibility that the missing low salinity shelf water of the mid 1990s (Steele and Boyd, 1998) could be mixed into the denser Barents Sea outflow in the St. Anna Trough, but estimated that the lower salinity of the Barents Sea inflow would only explain $10 \%$ of the loss of low salinity surface water in the Amundsen Basin.
McLaughlin et al. (2002) reported that the intermediate water in the Canada Basin had become colder and fresher between 1985 and 1995 with the largest changes between 1992 and 1995. This was interpreted as an inflow of newly ventilated Atlantic water from the Barents Sea, indicating a possible increase in the advection of Barents Sea branch water into the Amerasian Basin and Canada Basin connected with the highly positive AO and NAO state prevailing in the late 1980s and early 1990s. This change then appears to occur earlier than the warming of the Fram Strait inflow branch found in the Nansen Basin (Quadfasel et al., 1991) and the Makarov Basin (Carmack et al., 1995). This would agree with model results which suggest that the principal pathway for a wind driven increase of the Atlantic inflow would take place over the Barents Sea (Maslowski et al., 2000, 2004; Proshutinsky et al., 2011).

At the Laptev Sea slope the Barents Sea branch was observed to be colder, more saline, denser and located deeper in the water column in 2005-2006 than in 1995 (Dmitrenko et al., 2009). Their interpretation of these observation was that the wind pattern during the early 1990s over the Barents Sea caused a rapid flow through the Barents Sea, leading to less cooling, less ice formation (or more ice melt) and a less dense Barents Sea inflow than in the early 2000s when the winds were onshore. Onshore wind could prolong the transit time over the Barents and Kara seas and cause a stronger modification of the Barents Sea inflow than that taking place in the 1990s. This suggests that the less studied transformations of the Barents Sea inflow branch in the Barents Sea might be as important as the variations of the Fram Strait inflow characteristics for the advective changes observed in the Arctic Ocean basins.

\subsubsection{The Arctic Circumpolar Boundary Current}

The Arctic Circumpolar Boundary Current was the name suggested by Rudels et al. (1999c) when describing the transformations of the Atlantic water in the Arctic Mediterranean Sea as it circulates along the slope from the Norwegian Sea through Fram Strait around the Arctic Ocean deep basins and then returning through Fram Strait along the Greenland slope to exit through Denmark Strait and the Faroe Bank Channel. The same name is used by Aksenov et al. (2011) describing the circulation of the Arctic Ocean. They identify three Atlantic inflow stream, the "traditional" Fram Strait and Barents Sea inflow branches and one less dense Arctic Shelf Break Branch that is created in the Barents Sea by cooling and sea ice melt. This stream, present at the slope from the St. Anna Trough to western Fram Strait more belongs to the upper layers to be discussed in Section 4.2 and here we concentrate on the other two branches. The model results indicate that the Fram Strait branch is present at the boundary from Svalbard to Greenland, while the Barents Sea branch, starting at the St. Anna Trough, flows along the Siberian continental slope to the Chukchi Borderland, where it appears to partly leave the slope. In this model the denser part of the Barents Sea inflow is much weaker than the Fram Strait branch.

In an earlier model study Maslowski et al. (2004) examined the boundary current at $30^{\circ} \mathrm{E}$, east of Svalbard, and at $95^{\circ} \mathrm{E}$, north of Severnaya Zemlya. They found that only a small fraction ( $\sim 1.5 \mathrm{~Sv}$, ca $25 \%$ ) of the Fram Strait inflow joined the boundary current, the rest recirculated in Fram Strait. As the boundary current flows along the Kara Sea slope it is augmented by the incorporation of the substantially stronger (2.6 Sv) Barents Sea inflow branch. At the section north of Severnaya Zemlya the Barents Sea branch contributes, according to the model, about $80 \%$ of the volume and $15 \%$ of the heat flux, the Barents Sea branch being much colder than the Fram Strait branch. This dominance of the Barents Sea branch is different from the Aksenov et al. (2011) study. Surprisingly, in the Maslowski et al. model the Barents Sea branch also provides 
more salt (80\%) i.e. less freshwater than the Fram Strait branch. This appears rather unlikely considering the cooling and freshening taking place in the Barents Sea.

The two branches can be observed moving side by side on the eastern Kara Sea slope and Rudels (2012) compared the $\theta S$ structure of the Barents Sea branch with those from the other basins in the Arctic Ocean and noticed that, excluding the Nansen Basin, the temperature maximum of the Barents Sea branch was as warm or warmer than the temperature maximum observed in the other basins. This, and the fact that the warm saline core of the Fram Strait branch appears to be confined to the Nansen Basin, made Rudels (2012) propose that the Fram Strait branch is largely confined to the Nansen Basin and that the Atlantic layer present in the other basins is supplied by the Barents Sea branch. This idea was further elaborated by Rudels et al. (2013). There is one caveat. The properties of the Barents Sea branch were taken to be those observed on the upper $<600 \mathrm{~m}$ part of the eastern Kara Sea slope in 2007 and no documentation is available to show that part of the Atlantic water retains such high $\left(\sim 1^{\circ} \mathrm{C}\right)$ temperatures after crossing the Barents Sea. It is therefore possible that some of the warmer Fram Strait branch enters the St. Anna Trough, mixes with the Barents Sea branch and shifts stream, providing the warmer part observed on the slope. In any case, it is conceivable that the Arctic Circumpolar Boundary Current is not quite continuous. From the Barents Sea opening to Severnaya Zemlya Sea it is supplied by the Fram Strait branch but from Severnaya Zemlya, around the Arctic Ocean to Fram Strait, the water would derive from the Barents Sea branch.

\subsection{The upper layers and the halocline}

The increased observational activity in recent years has revealed a more complex structure of the halocline, especially in the Canada Basin. The Pacific derived upper halocline, centred on salinity 33.1, is not only associated with a high nutrient, low oxygen water mass. Also a high oxygen mode of the upper halocline water with similar $\theta S$ characteristics has been observed. One hypothesis (Shimada et al., 2005) is that the differences are caused by different pathways taken by the, to be, halocline waters across the Chukchi shelf. One, rapid, path down the Herald Canyon would involve little interaction with the bottom sediments, allowing the oxygen content to remain high, while on the second path farther to the east a longer time is spent in contact with the sediments leading to remineralisation and higher nutrient and lower oxygen concentrations (Fig. 21). Apart from the Pacific water Fig. 21 also shows two modes of the Atlantic derived lower halocline water, one colder oxygen rich and one warmer, oxygen poor lower halocline water mass.

Halocline water with salinities close to 34 and with high oxygen content has been observed north of the Chukchi Borderland (Shimada et al., 2004; McLaughlin et al., 2004). As a source for this high oxygen halocline water McLaughlin et al. (2004) suggested the shelves of the East Siberian Sea. This is, however, a rather unlikely location due to the large freshwater content and thus low salinity found in the East Siberian Sea. More than $2 \mathrm{~m}$ of ice must be formed to attain salinities between 33 and 34 (Aagaard et al., 1981), which made Aagaard et al. (1981) exclude it as a possible source for shelf derived halocline waters.

Rudels et al. (2004) studying the formation of Atlantic derived lower halocline waters favoured the explanation that during the high NAO index situation in the 1990s the area, where a locally ventilated high salinity mixed layer reached down to the thermocline, extended from the Nansen Basin into the Amundsen Basin and possibly also into the Makarov Basin. This could create a well ventilated and oxygen rich water mass close to the Chukchi Borderland and when this mixed layer is covered by low salinity shelf water and becomes a halocline advected towards the Chukchi Borderland its oxygen content would still be high.
The Barents Sea has always been considered a possible source for the lower halocline water, identified as a bend in the $\theta S$ curves around 34.4. The formation process could either be upwelling and subsequent dilution and cooling of Atlantic water on the shelf (Coachman and Barnes, 1962), or freezing and brine rejection leading to accumulation of dense water at the shelf bottom (Aagaard et al., 1981). In both cases the formed, or modified, water is injected into the Arctic Ocean water column between the Polar Mixed layer and the Atlantic water. A more recent idea has been that the melting of sea ice at the marginal ice zone in the Barents Sea would create a water mass with lower halocline properties that could enter the Arctic Ocean through the Kara Sea and then return towards Fram Strait (Steele et al., 1995).

Rudels et al. (2004) proposed that the melting of sea ice on top of the warm Atlantic water would, similar to the situation north of Svalbard, create a less saline surface layer that becomes homogenised by cooling and ice formation in winter also in the northern Barents Sea as well as west of Novaya Zemlya and in the northern Kara Sea. This upper layer then moves as a part of the main Barents Sea branch into the Arctic Ocean across the Kara Sea shelf break. There it follows the continental slope eastward on the shelf side of the winter mixed layer of the Fram Strait branch. Both layers become covered by less dense shelf water north of the Laptev Sea and are transformed into halocline waters. The Fram Strait branch halocline spreads from the slope into the Amundsen and Makarov basins and into the Canada Basin up to the Chukchi Borderland. The temperature minimum and the halostad, both marking the depth of the winter convection, become slowly eroded by turbulent mixing from above and below, but a clear bend close to 34.3 still identifies the original properties of the Fram Strait branch winter mixed layer. The initially more saline Barents Sea branch halocline stays at the slope, where stronger mixing with the underlying Atlantic water, perhaps driven by tidal motions, more rapidly increases the temperature (Dewey et al., 1999), and the Barents Sea branch halocline becomes both more saline and warmer than the Fram Strait halocline as is seen from the profiles and $\theta S$ curves shown in Fig. 22. The Barents Sea branch halocline water continues along the slope past the East Siberian Sea and passes between the slope and the Chukchi Borderland into the southern Canada Basin, where it supplies the water of the lower halocline. Rudels et al. (2004) identified the evolved properties of the Barents Sea halocline water as similar to those of the Baffin Bay deep and bottom waters and suggested that it partly leaves the Arctic Ocean through Nares Strait and supplies the bottom water of Baffin Bay. Fig. 23 shows a schematic of the formation and circulation of the lower halocline water in the Arctic Ocean. The formation and circulation of the Barents Sea halocline water would then be similar to those of the Arctic Shelf Break Branch identified by Aksenov et al. (2011) in their numerical model.

The lower halocline in the Canada Basin has higher silicate content than in the Makarov Basin, indicating that some silicate rich Pacific water must be made dense enough by brine rejection on the Chukchi shelf to penetrate into the lower halocline (Salmon and McRoy, 1994). Another possibility would be direct mixing between the Pacific water and the underlying Atlantic derived halocline waters (Woodgate et al., 2005a). This would then imply that the temperature and salinity characteristics of the Canada Basin lower halocline are created north of the Chukchi Sea, not farther west as was proposed by Rudels et al. (2004).

From mooring data north of the Laptev Sea Woodgate et al. (2001) observed two different modes of halocline water, one cold mode, which would correspond to the Fram Strait halocline water, and one warmer and slightly more saline, which they suggested originated from the Barents Sea, formed by the shelf process suggested by Aagaard et al. (1981). The two haloclines waters would then be meandering along the continental slope, either one or 
(a) Potential Temperature
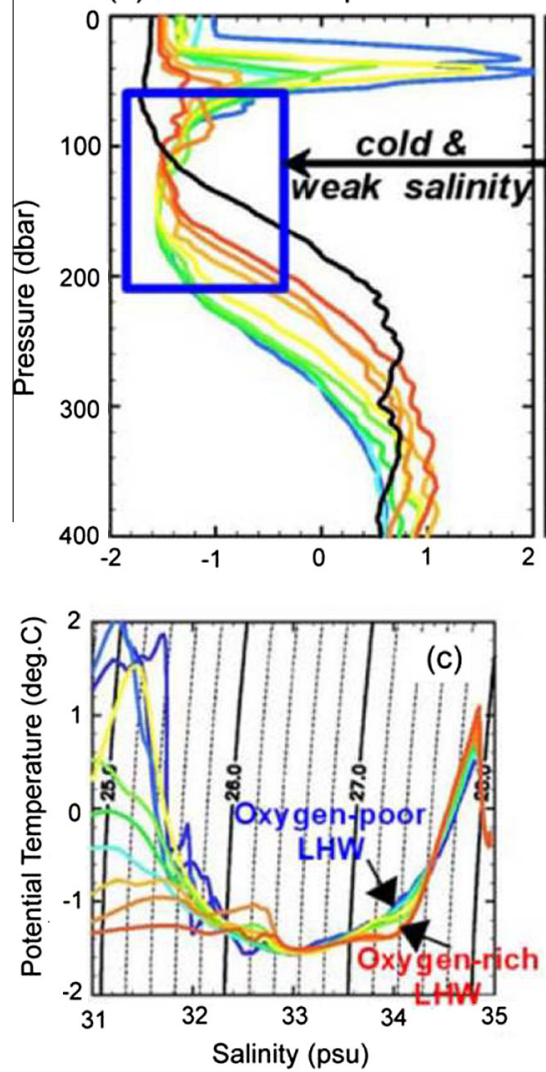

(b) Salinity
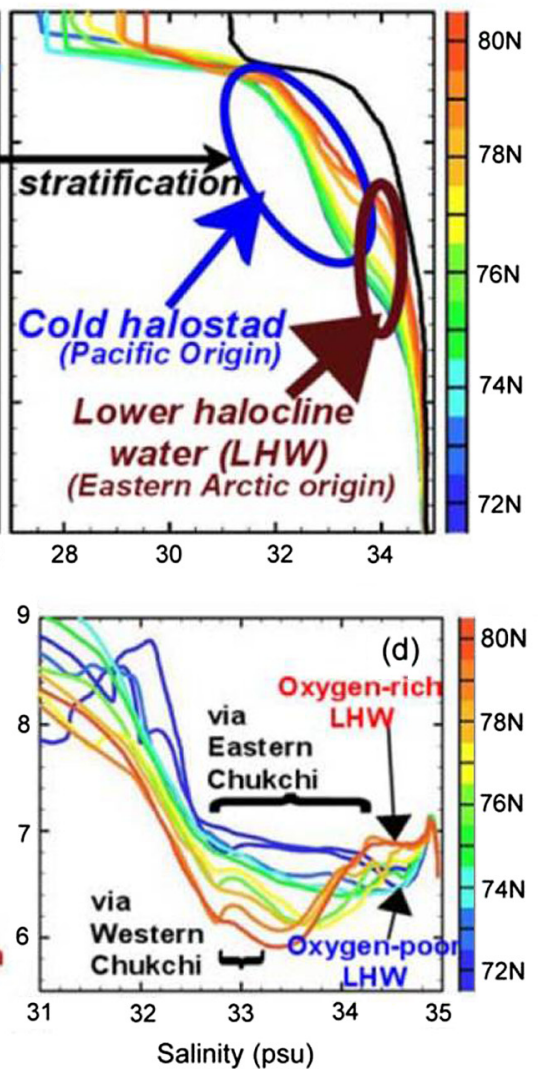

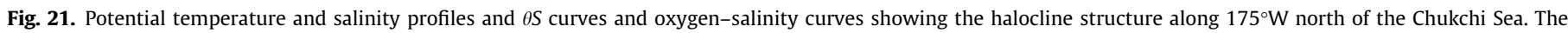
black station is from the Makarov Basin (from Shimada et al., 2005).
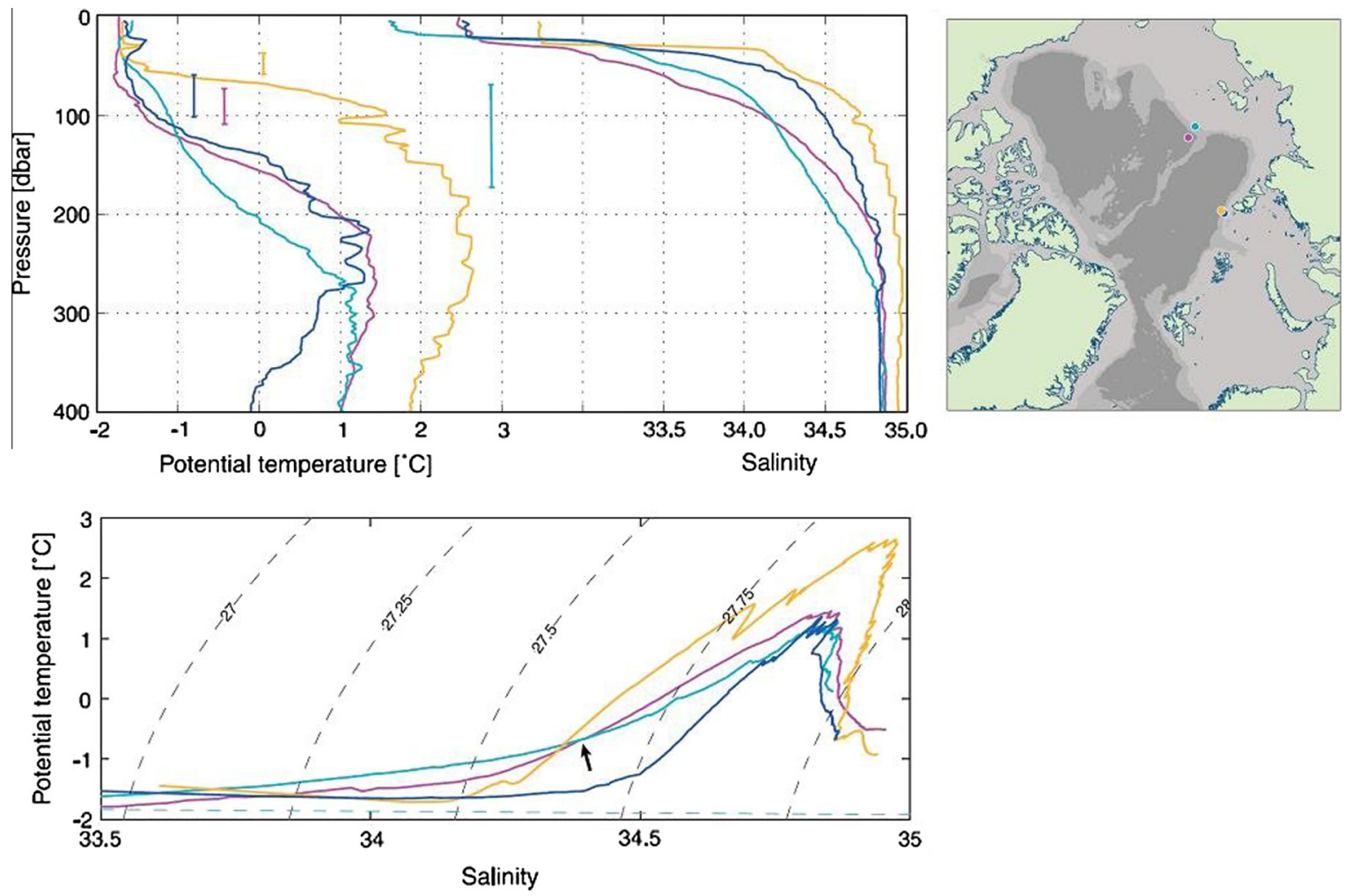

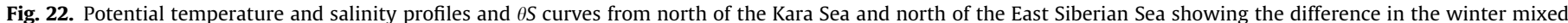

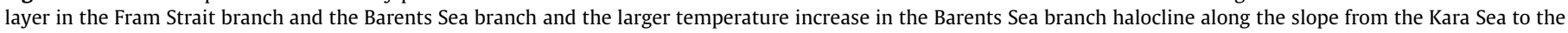
East Siberian Sea. Data from Polarstern 1995 (from Rudels et al., 2004). 


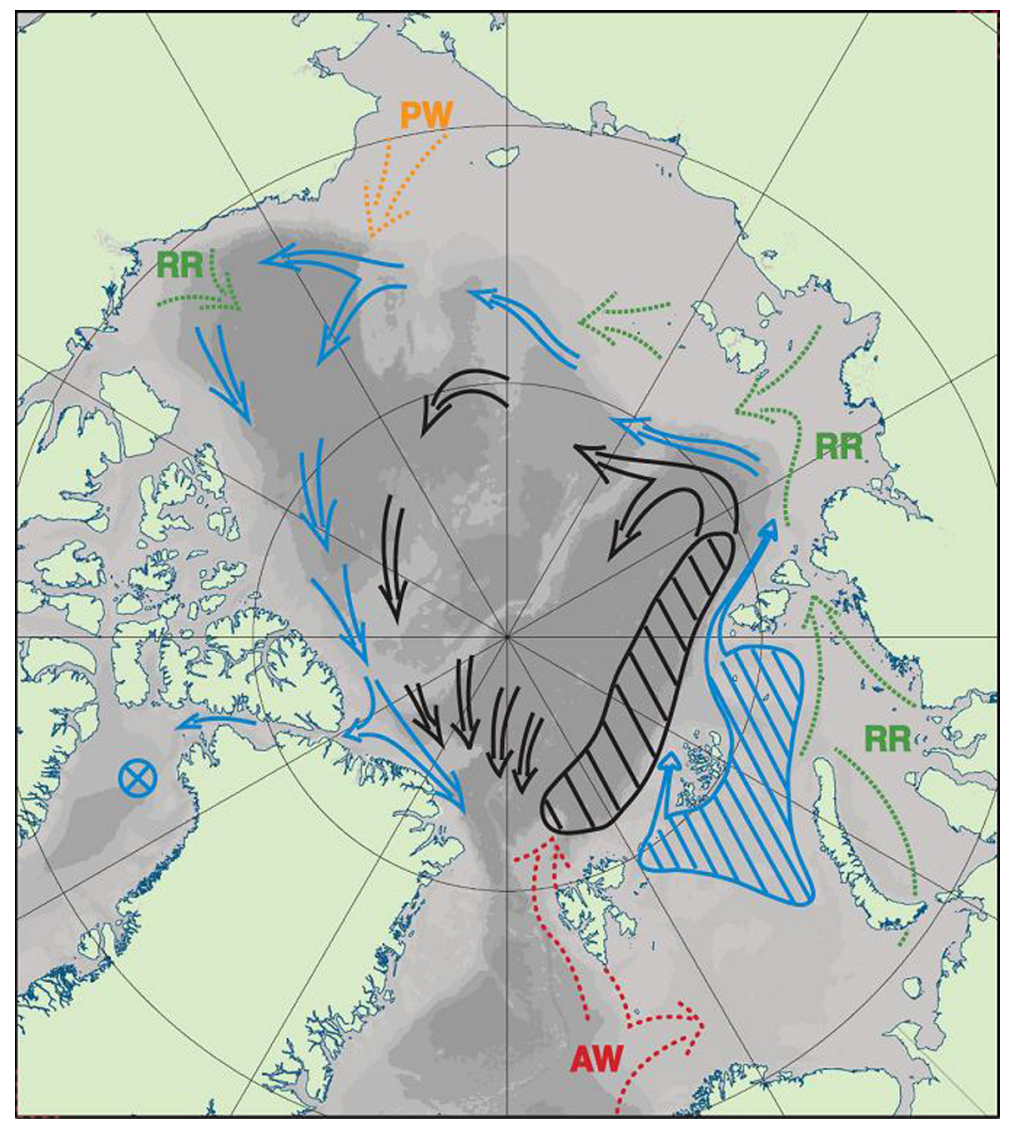

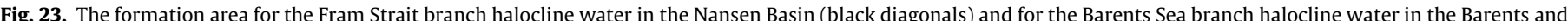

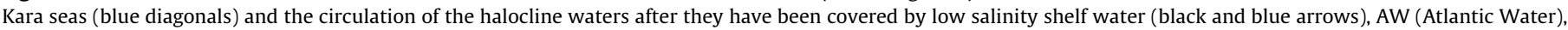
PW (Pacific Water), RR (River runoff) (from Rudels et al., 2004).

the other passing the mooring position. However, regardless of how the halocline water in the Barents Sea is formed, by accumulation at the shelf bottom or from an initially fairly saline mixed layer, the Barents Sea branch halocline appears to attain much of its distinct properties, close to those observed in the southern Canada Basins, already in the Eurasian Basin.

The presence of a cold halocline between the about $40 \mathrm{~m}$ thick Polar Mixed Layer and the Atlantic water implies that water entrained in the mixed layer is cold and do not supply heat either to ice melt or to the atmosphere The absence of a cold halocline above the Atlantic water, as was observed over a large part of the Eurasian Basin in the mid 1990s, therefore actualised the question of how vertical transfer of heat from the Atlantic layer to the surface might influence the thickness and compactness of the ice cover. North of Svalbard, where the Atlantic water meets the sea ice, ice melts and wind mixing transforms the upper part of the Atlantic water into a cold, less saline upper layer. In winter cooling and wind mixing homogenise and deepen this upper layer, entraining warmer Atlantic water from below. The stability and depth of the upper layer increases and eventually the temperature reaches the freezing point and the heat stored in the upper layer is gone. The salinity of the upper layer is then higher than if all heat had been used to melt ice, implying that a large fraction of oceanic heat goes directly to the atmosphere. In fact, the density step caused by the salinity reduction is twice the density step due to the temperature difference between the upper and the Atlantic layer, implying that higher temperature in the Atlantic layer leads to stronger stability (Rudels et al., 1999b). When the upper layer reaches the freezing point, the heat entrained from below is not sufficient to balance the heat loss to the atmosphere and to ice melt. Sea ice starts to reform, increasing the salinity of the upper layer and reducing the stability. However, in the Arctic Ocean the stability is so strong that this will not lead to an overturning of the upper layer. Only if the initial layer is cold could the stability be weak enough that convection out of the upper layer could take place within one winter season (Rudels et al., 1999b; Rudels, 2010).

In the interior of the Arctic Ocean the situation is different. A low salinity upper layer exists, which in summer is covered with an even less saline melt water layer. Ice formation then removes the summer melt in fall and brine rejection and haline convection homogenise the upper layer and in the Nansen Basin the convection eventually reaches down to the thermocline. Indications that this occurs can be seen by comparing $\theta S$ curves from the entrance area north of Fram Strait, where the wind induced mixing dominates, with $\theta S$ curves from areas in the interior of the Nansen Basin, where the mixed layer extends down to the thermocline in winter. North of Fram Strait the mixing line between the mixed layer and the temperature maximum of the Atlantic layer is straight, implying mechanical mixing (Rudels et al., 2005). In the Nansen Basin, by contrast, the mixing line between the cold upper layer and the temperature maximum of the Atlantic layer is curved into a shape similar to that of an isopycnal (Rudels et al., 1996) (Fig. 24). This suggests that convection allows cold, dense water from the surface to penetrate into and cool the upper part of the thermocline. Instead of stirring heat into the upper layer, to be lost to the atmosphere and to ice melt, cold convecting brine enriched plumes and isolated parcels enter and cool the upper part of the thermocline at depth (Rudels and Friedrich, 2000; Kikuchi et al., 2004). The process is shown schematically in Fig. 24. 


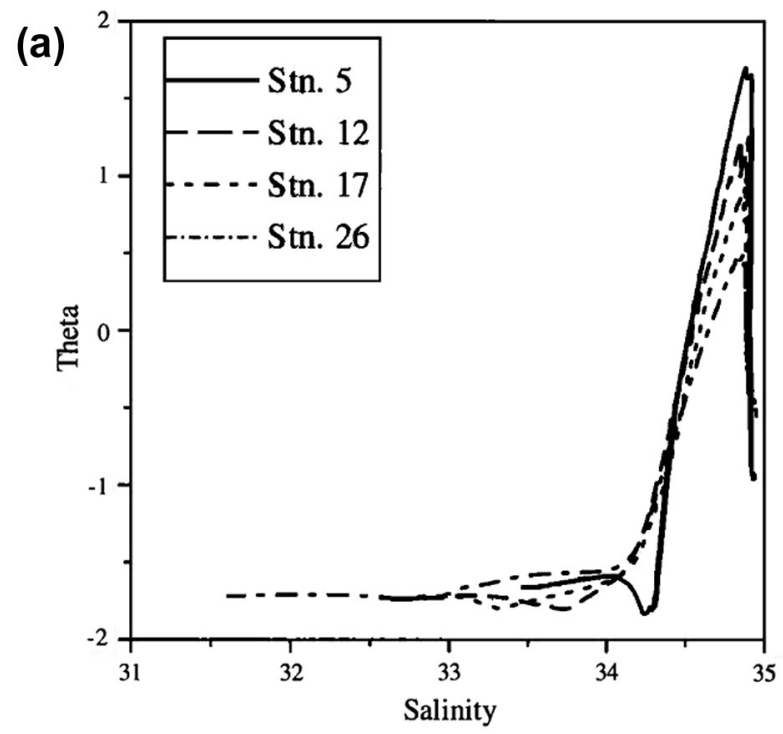

(b) (a) Upstream condition

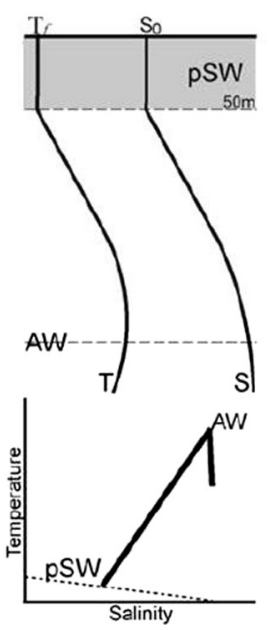

(b) Freezing

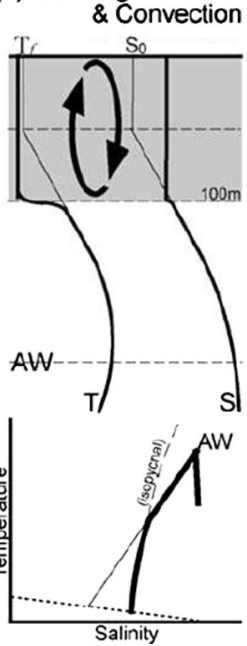

(c) Sea Ice Melting

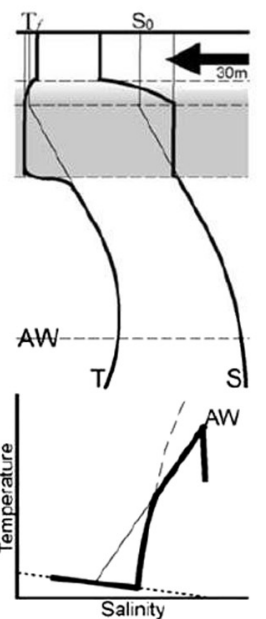

(d) Refreezing

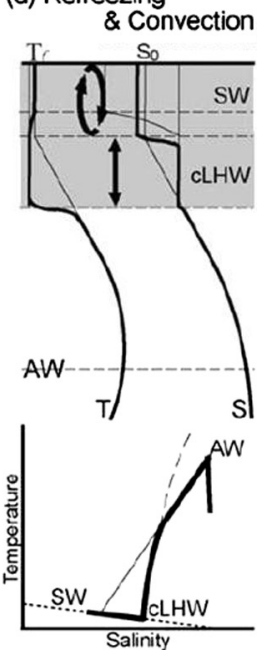

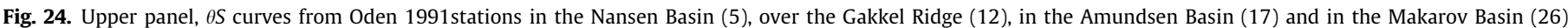

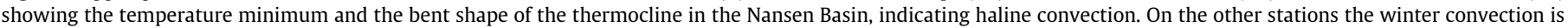

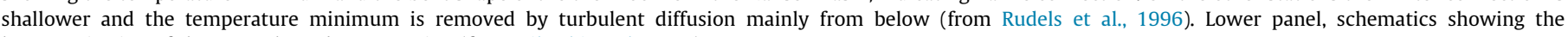
homogenisation of the upper layer by convection (from Kikuchi et al., 2004).

Furthermore, if heat brought into the upper layer by convection is used to melt ice, the brine rejection and the haline convection would weaken, reducing the heat flux from below. Entrainment generated by haline convection is thus a self-regulating process. If too much heat is entrained, less ice will form and the convection weakens, the entrainment stops and heat loss to atmosphere and ice melt removes the heat and ice again start to form, again leading to brine rejection and new entrainment (Martinson and Steele, 2001). This implies that the ice cover, at least in the deep basins of the Arctic Ocean, is not likely threatened by heat flux from the Atlantic layer. At the continental slope the mixing lines in the $\theta S$ diagram are straight, indicating that the mixing is dominated by mechanically generated turbulence and a larger upward heat transport would be present (Dewey et al., 1999).

\subsection{The thermocline and double-diffusive transports}

New techniques and the increased observational coverage and frequency provided by the Ice-Tethered-Platforms (ITP) made it possible to study the characteristics of the diffusive interfaces and thermohaline steps first observed from T3 ice island (Neal et al., 1969) and the AIWEX ice camp (Padman and Dillon, 1987) in detail and for longer periods and over large areas. The rising speed of the ITPs is $0.25 \mathrm{~ms}^{-1}$, and its observational frequency $1 \mathrm{~Hz}$, which gives a vertical distance of $25 \mathrm{~cm}$ between the observations. This cannot dissolve the structure of the interfaces, which have a thickness of $\sim 5 \mathrm{~cm}$. Actually the interfaces are rarely sampled and the overwhelming number of observations will be from the homogenous layers (Timmermans et al., 2008).

When collecting observations over a longer time and from several ITPs the observations plotted on a $\theta S$ diagram tend to form vertically elongated clusters, the layers, separated by empty spaces, the interfaces, as seen in Fig. 25 (Timmermans et al., 2008). This suggests an extensive lateral coherence of the layers and Timmermans et al. (2008) estimate that the individual layers, a few metres thick, extend over $800 \mathrm{~km}$, implying the almost unbelievable vertical to horizontal ratio of $\sim 1 / 200,000$. The range in temperature of the individual clusters describes the evolution of the layer in time and space. When the Atlantic water enters the Canada Basin the temperature of its temperature maximum is high and the upper 


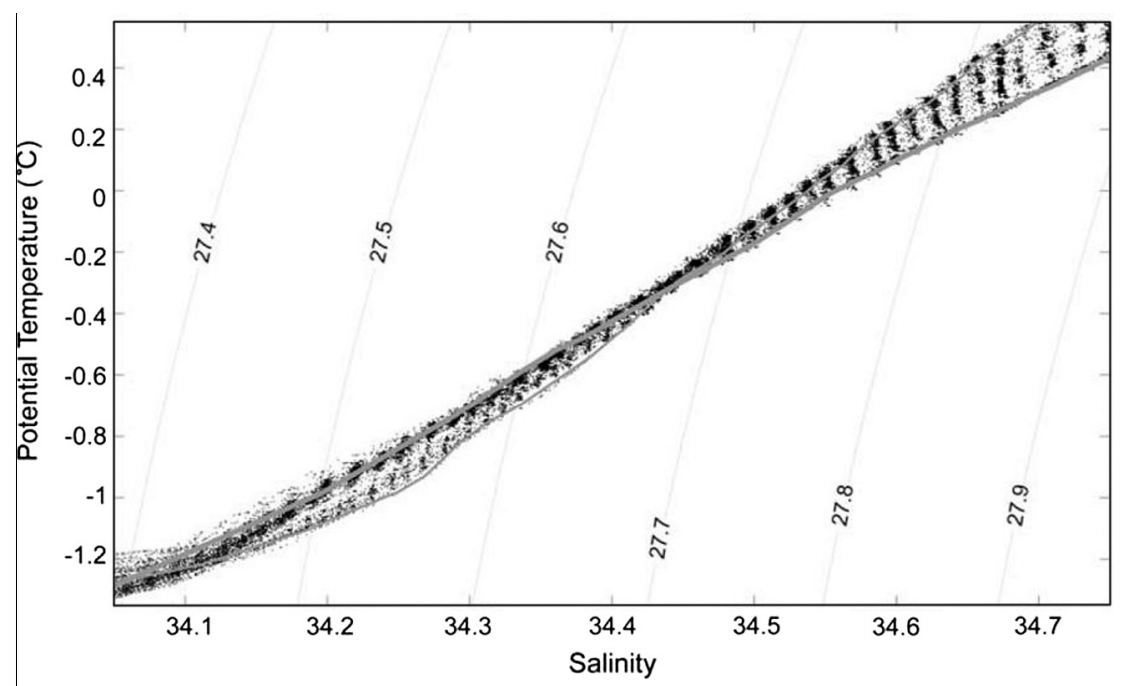

(a)

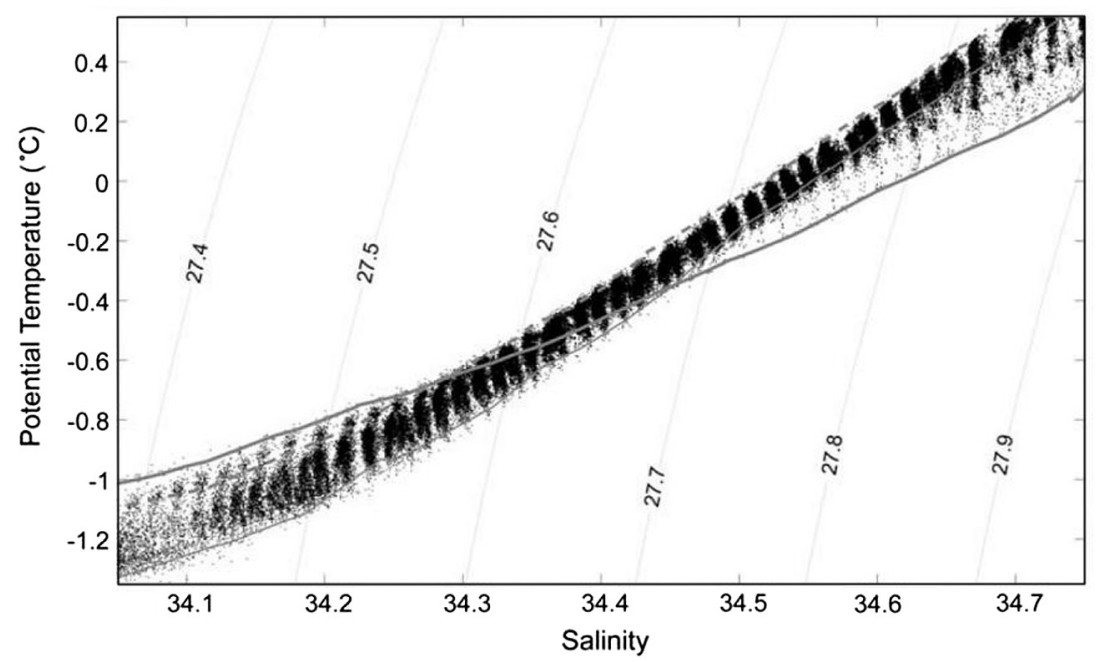

(b)

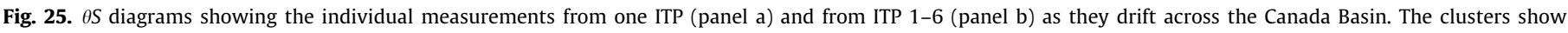

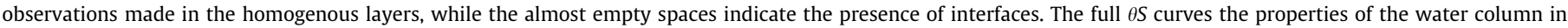

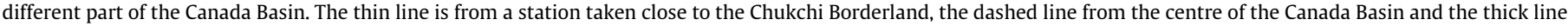
from the continental slope close to the Canadian Arctic Archipelago (from Timmermans et al., 2008).

part of the thermocline is cold. As the water circulate in the Canada Basin heat is transferred from the warm core through the diffusive interfaces to the cold upper part, and the $\theta S$ curves become flatter. The central part would display the smallest vertical ranges because the heat is mainly fluxed through these layers, not changing their temperature.

The Atlantic water and the thermocline probably need about $10-20$ years to pass through the Canada Basin and it is remarkable that the layers in the newly entered waters should line up with those that have been present in the basin for more than a decade. Especially since double-diffusive convection at diffusive interfaces essentially is a vertical process. However, from the observations of diffusive steps made on AIWEX ice camp Padman and Dillon (1988) could not trace individual steps on profiles more than $1000 \mathrm{~m}$ apart. The microstructure measurements conducted by Sirevaag and Fer (2012) from the ice camp Borneo at the North Pole also did not indicate such large spatial coherence. After about 5 successive casts with the microstructure probe individual layers could no longer be identified and followed.
The heat fluxes obtained for the diffusive interfaces in the Canada Basin from the ITP observations using the laboratory $4 / 3$ flux law proposed by Kelley (1990) were between 0.05 and $0.3 \mathrm{~W} \mathrm{~m}^{-2}$ (Timmermans et al., 2008). This is a factor 2-3 larger than the fluxes reported by Padman and Dillon (1987) but the positions are not exactly the same, and it is not possible to definitely relate this increase to the warmer Atlantic water passing through the Canada Basin in the 2000s (Timmermans et al., 2008). The vertical heat flux is in any case small and its influence on e.g. the ice cover would be almost negligible. That is, if it could penetrate through the intermediate halocline and reach the mixed layer and the ice, which is not likely.

Sirevaag and Fer (2012) used microstructure measurements to directly determine the vertical heat flux in the interior of the Amundsen Basin. They found a vertical heat flux of $0.07 \pm 0.09 \mathrm{~W} \mathrm{~m}^{-2}$, which almost an order of magnitude lower than the transport obtained using the flux law formulated by Kelley. The measured heat flux was only slightly larger than the computed molecular heat flux $0.05 \pm 0.04 \mathrm{~W} \mathrm{~m}^{-2}$. The vertical heat transport 
due to diffusive interfaces then does not seem to be of importance for the ice cover also in the Amundsen Basin, where the halocline layer is thinner and the thermocline closer to the mixed layer.

Lenn et al. (2009) studied the possible effect of double-diffusive heat transfer in the boundary current north of the Laptev and East Siberian seas using microstructure measurements and hydrographic observations. They found a slightly higher double-diffusive heat flux, $\sim 1 \mathrm{~W} \mathrm{~m}^{-2}$ compared to Sirevaag and Fer (2012) but concluded that this flux could not account for the observed changes in the Atlantic layer taking place as it is advected along the slope and suggested lateral mixing with other water masses, mainly originating from the shelves to explain the observed changes.

Polyakov et al. (2012b) using observations from a McLane profiler moored at the Laptev Sea slope identified several persisting layers being advected by the boundary current past the instrument. The layers formed similar clusters as those observed in the Canada Basin but with the temperature variations caused by the changing properties of the boundary current. The vertical distance between the observation points were $12 \mathrm{~cm}$ and by using the Kelley laboratory flux law (Kelley, 1990) they obtained a vertical heat flux of 7-8 $\mathrm{W} \mathrm{m}^{-2}$, significantly larger than Lenn et al. (2009) and concluded that the fluxes through double-diffusive interfaces might be important in explaining the state of the ice cover in the Eurasian Basin. The question still remains how well do the laboratory flux laws represent the reality (Sirevaag and Fer, 2012) and do the observations from the McLane profiler have sufficient vertical resolution to apply these laws adequately.

The Nansen Basin is perhaps the only part of the Arctic Ocean, where the heat flux through diffusive interface might be of importance. Here the thermocline is thin and in direct contact with the mixed layer. The temperature differences across the interfaces and the layer thicknesses are large (e.g. Rudels et al., 2009). The stability ratio is often below 2 indicating strong diffusive fluxes. In combination with haline convection in winter this heat might be stirred into the mixed layer and eventually reach the sea surface and the ice and possibly reduce the ice formation somewhat.

\subsection{The deep and bottom waters}

The increased number of deep stations occupied in the Arctic Ocean during the last 20 years and the higher accuracy of the measurements have revealed differences between the deep and bottom waters in the separate basins more subtle than just higher temperatures and salinities in the Amerasian Basin as compared to the Eurasian Basin. The salinity and temperature is lower in the Nansen Basin at $2500 \mathrm{~m}$ depth around the Yermak Plateau than in the rest of the Eurasian Basin, indicating an inflow of cold, less saline water from the Nordic Seas (Rudels et al., 2000b). The inflow was postulated by Nansen in the earlier part of the 20th century. This signal in temperature and salinity disappears rather quickly towards the north and east but the Nordic Seas deep inflow is still noticeable along the Siberian slope in other parameters and tracers (e.g. Frank et al., 1998; Smethie et al., 2000).

The salinity increases towards the bottom in all basins and in the Amundsen Basin there is, in addition, a mid-depth salinity maximum centred around $1700 \mathrm{~m}$ depth (see e.g. Fig. 20). The temperature in the Nansen, Amundsen and Canada basins decreases to a minimum and then increases slightly until a thick, $1200 \mathrm{~m}$ in the Canada Basin, $800 \mathrm{~m}$ in the Amundsen Basin and $400 \mathrm{~m}$ in the Nansen Basin, isothermal and isohaline bottom layer is reached. The Makarov Basin is different. No temperature minimum is present and the temperature continues to decrease a few hundred meters after the salinity has become constant until it reaches a $600 \mathrm{~m}$ deep isothermal and isohaline bottom layer.

The warmer and homogenous bottom layer in the Canada Basin is separated from the colder, less saline layer above by sharp, extensive diffusive interfaces. This made Timmermans et al. (2003) propose that the bottom layer in the Canada Basin is a relic from a convection period taking place perhaps 500 years ago (Macdonald et al., 1993), which is now gradually becoming warmer due to geothermal heat flux from the sea floor. The induced convection and the rising warm water would stir the bottom layer, keeping it isothermal and isohaline. The temperature increase, however, appears to be smaller than anticipated from the estimates of geothermal heat fluxes and Timmermans et al. (2003) looked for mechanisms that could allow the heat to pass upward from the bottom layer. One obvious candidate would be double-diffusively driven transports through the diffusive interfaces, but the existing laboratory flux laws for diffusive interfaces indicate that such heat flux would not be sufficient. Timmermans et al. (2003) therefore proposed that vertical mixing at the basin boundaries was the most likely process for bringing heat upwards from the bottom layer. Björk and Winsor (2006) reported an increase in the bottom temperatures in the Amundsen Basin between 1991 and 2001 and also attributed this to geothermal heating, the bottom layer becoming gradually warmer and homogenised as the temperature increases and the boundary of the bottom layer migrates upwards.

Geothermal heating presents quite a different picture than that of sinking, entraining shelf-slope plumes bringing saline shelf water as well as entrained heat from the Atlantic and intermediate waters into the deep and bottom layers (e.g. Rudels, 1986a). Warm, saline plumes originating from Storfjorden have been observed in Fram Strait (Quadfasel et al., 1988; Schauer, 1995; Rudels et al., 1999c; Schauer and Fahrbach, 1999) (see also Fig. 10 above) and in 1995 similar warmer, more saline and denser bottom layers were observed in the Nansen Basin at the continental slope north of Severnaya Zemlya (Rudels et al., 2000a). However, these scenarios are not exclusive, being driven by two completely decoupled processes, geothermal heating at the bottom and cooling and ice formation at the surface. In different periods one or the other might be the most important one in determining the characteristics and evolution of the bottom layers in the deep Arctic Ocean basins.

The deep temperature minimum in the Canada Basin has similar characteristics as the deep water at the same level in the Makarov Basin and can be explained by an inflow of colder water from the Makarov Basin across the Alpha and Mendeleyev ridges and this has been discussed by Timmermans and Garrett (2006). The minima in the Nansen and Amundsen basins are not so easy to explain by advection, since they are too dense and located too deep to be supplied by the inflow of colder deep water from the Nordic Seas (Fig. 20). Rudels et al. (2000a) suggested that the temperature minima present above the homogenous bottom layer in the Nansen and Amundsen basins originated from a denser, perhaps intermittent, bottom water mode of the Barents Sea inflow branch. Saline and dense water formed by brine rejection in the eastern Barents Sea would flow into the Arctic Ocean via St. Anna Trough. There it enters below the main part of the warm Atlantic and intermediate waters and entrains less warm water. This leads to a smaller temperature increase and also implies that a lower initial salinity might be required to reach the deeper layers. Such inflow could show up as a deep, below $3000 \mathrm{~m}$, temperature minimum. The more saline shelf water contributing to the bottom water would, by contrast, be formed in the eastern Kara Sea and around Severnaya Zemlya, where warmer, more saline and denser bottom water has been observed on the continental slope off Severnaya Zemlya (Rudels et al., 2000a). Here the distance to the shelf break is short and the dense shelf water does not experience much dilution before it crosses the shelf break and starts to sink down the slope. It would pass through the cold Barents Sea branch water column and entrain less warm water than e.g. plumes originating from the Chukchi Sea, where Atlantic water with temperature $>0{ }^{\circ} \mathrm{C}$ 
forms the bottom water over a part of the slope. The plumes, however, entrain sufficient amount of intermediate water to become warmer than the dense water passing down the St. Anna Trough and would require a higher initial salinity to reach the bottom. The presence of these two sources could explain the deep temperature minimum and the structure of the deep and bottom part of the Nansen Basin and Amundsen Basin water columns.

The absence of a deep temperature minimum in the Makarov Basin and the fact that the temperature in the deeper layers is lower than expected from shelf-slope convection made Jones et al. (1995) propose that the low temperatures were due to a spillover of deep water from the Amundsen Basin to the Makarov Basin across the central part of the Lomonosov Ridge away from the continental slope and the boundary current. The sinking of colder Amundsen Basin water into the deep Makarov Basin would be aided by its higher compressibility (the thermobaric effect) and it would entrain less warm water than the slope plumes and thus balance their influence on the temperature in the deep Amerasian Basin water column. Jones et al. (1995) also assumed that the flow crossing the ridge might be forced by internal, topographically trapped waves, moving along the Lomonosov Ridge.

In more recent bathymetric maps of the Arctic Ocean (e.g. Jakobsson et al., 2000) a deep intra-basin was shown within the Lomonosov Ridge, indicating a possible sill depth of $2500 \mathrm{~m}$, and the area where a possible flow of Amundsen Basin deep water into the Makarov Basin could occur was expected to be located at $88^{\circ} 25^{\prime} \mathrm{N}, 150^{\circ} \mathrm{E}$. Timmermans et al. (2005) proposed that a rotationally controlled flow takes place through this passage from the Amundsen Basin to the Makarov Basin. In 2005 IB Oden and USCGC Healy crossed the Arctic Ocean from Alaska to Svalbard. One of the objectives of this expedition was to examine the bathymetry of the intra-basin in the Lomonosov Ridge, determine the sill depth to the Makarov Basin, and study the possibility of a flow through the passage. The expedition found no passage deeper than $1870 \mathrm{~m}$, and the expected flow of dense Amundsen Basin deep water into the Makarov Basin was not observed. Instead the layer in the intra-basin between $1700 \mathrm{~m}$ and $2300 \mathrm{~m}$ was dominated by water from the Makarov Basin, and on the Amundsen Basin side of the Lomonosov Ridge a salinity maximum centred at $2000 \mathrm{~m}$ was observed (Björk et al., 2007). This implied an inflow of Makarov Basin deep water into the Amundsen Basin. On the neighbouring station, $25 \mathrm{~nm}$ away from the ridge, the maximum was strongly reduced, suggesting that the inflow follows the ridge towards Greenland (Björk et al., 2007). No continuous deep flow from the Amundsen to the Makarov Basin was detected. The exchanges across the Lomonosov Ridge suggested to explain the deep water characteristics of the Makarov Basin, should they occur, must take place elsewhere or be intermittent.

Rudels (2012) examined earlier observation made from IB Oden in 2001 and noticed that two stations obtained then and shallower than the sill depth, were located very close to the sill and both stations had a colder, less saline bottom water indicating presence of Amundsen Basin deep water above sill depth. The density of the water relative to $2000 \mathrm{db}$ was high enough for this water to sink down to $2400 \mathrm{~m}$ and its density relative to $4000 \mathrm{db}$ was higher than that of the Makarov Basin bottom water. Rudels (2012) suggested that the exchanges were dependent upon the pressure gradient at sill depth. In 2005 the water column above $2000 \mathrm{~m}$ was less dense in the Amundsen Basin compared to the Makarov Basin and the negative pressure gradient at $2000 \mathrm{~m}$ would be directed from the Makarov to the Amundsen Basin. In 1996, when Polarstern crossed the Lomonosov Ridge, the water column in the Amundsen Basin was denser than that in the Makarov Basin (Rudels, 2012).

The salinity maximum at $1700 \mathrm{~m}$, which has been observed in the Amundsen Basin, had already been hypothesised as originating from the Amerasian Basin (Anderson et al., 1994). However, it was then assumed to enter in the boundary current along the continental slope. The flow would then bifurcate at the Morris Jesup Plateau, one part penetrating into the Amundsen Basin and along the Gakkel Ridge and the rest exiting through Fram Strait into the Nordic Seas (Jones et al., 1995). The inflow of Makarov Basin water, observed at the central part of the Lomonosov Ridge, might, however, be the principal source of this mid-depth salinity maximum, especially since the sill depth of the Lomonosov Ridge determined north of the North American continent so far has not exceeded $1200 \mathrm{~m}$ (Björk et al., 2007). However, the pathway into the Amundsen Basin still appears to be from the boundary current north of Greenland, not directly from the Lomonosov Ridge as indicated on the schematics on Fig. 26 (Björk et al., 2007, 2010).

The Arctic Ocean deep waters, both from the Amerasian Basin and from the Eurasian Basin, exit through Fram Strait and contribute to the deeper layers in the Nordic Seas. Presently, when the convection in the Greenland Sea produces Arctic Intermediate Water (AIW) but no deep water, the Arctic Ocean deep waters provide the most vigorous renewal of the deeper layers in the Greenland Sea. The Amerasian Basin deep water supplied (until 2010) a mid-depth temperature maximum and the Eurasian Basin deep water input increases the salinity and the temperature of the deeper layer, reducing the remnants of the colder, less saline locally produced Greenland Sea bottom water still found in the deepest part of the Greenland Sea (Rudels, 1995; Meincke et al., 1997; Budéus and Ronski, 2009; Rudels et al., 2012).

\subsection{The importance of the atmospheric circulation}

That the wind drives the sea ice and the water just beneath the ice has been known since Nansen and Ekman in the beginning of the last century. However, in addition to the direct wind drift the spatial variations of the wind field create convergences and divergences of the Ekman transport, leading to local accumulation or thinning of the surface layer. This changes the density field and generates a baroclinic flow field affecting a large part of the water column.

The atmospheric circulation patterns identified in the 1990s, e.g. the NAO and the AO, clearly influence the circulation in the Arctic Ocean. In the positive NAO (AO) phase the anti-cyclonic circulation in the Beaufort gyre is weakened, while in the negative phase it is strengthened. In the first situation the low salinity upper layer storage is reduced, in the second increased. Proshutinsky and Johnson (1997), building upon earlier Russian studies (e.g. Sokolov, 1962) and taking into account not only the variation in the atmospheric circulation but also the varying input of freshwater from the rivers and sea level variations, introduced an Arctic Ocean Oscillation index (AOO), which in its positive phase indicates a strengthening of the Beaufort gyre and a weakening of the gyre in its negative phase. The low salinity upper layer or the freshwater storage in the Beaufort gyre is high when AOO is positive, while when the AOO is negative the low salinity upper water is displaced towards the rim of the basins (Fig. 27).

Proshutinsky and Johnson (1997) also discussed the two views of how the circulation in the Arctic Ocean and its exchanges with the world ocean could be driven. One view maintains that the thermohaline forcing in the Arctic Ocean dominates. Cooling and river runoff, freezing and melting create the density field, which drives the circulation and the exchanges. The other view stresses the primacy of the wind. The effects of the wind forcing are clearly seen in the spinup and spindown of the Beaufort gyre. However, the two forcing modes are coupled because the wind drift changes the density distribution and thus influences the baroclinic velocity field. If no water mass transformations were taking place, only barotropic currents would be generated. The all important question, at least 

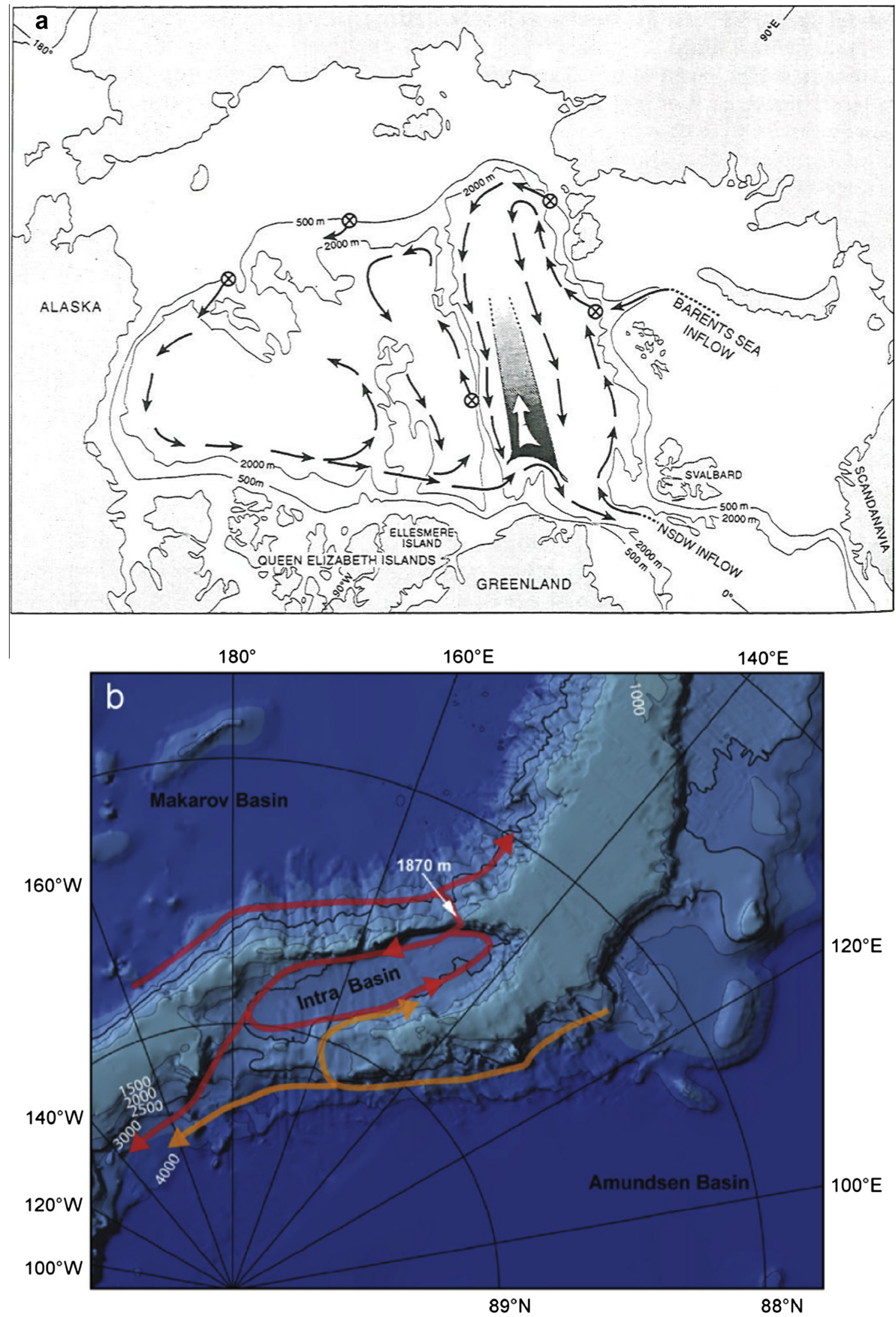

Fig. 26. Upper panel, the deep water circulation proposed by Jones et al. (1995). The lower panel, the deep circulation between the Amundsen and Makarov basins inferred from the observation made from Oden 2005 (from Björk et al., 2007). 

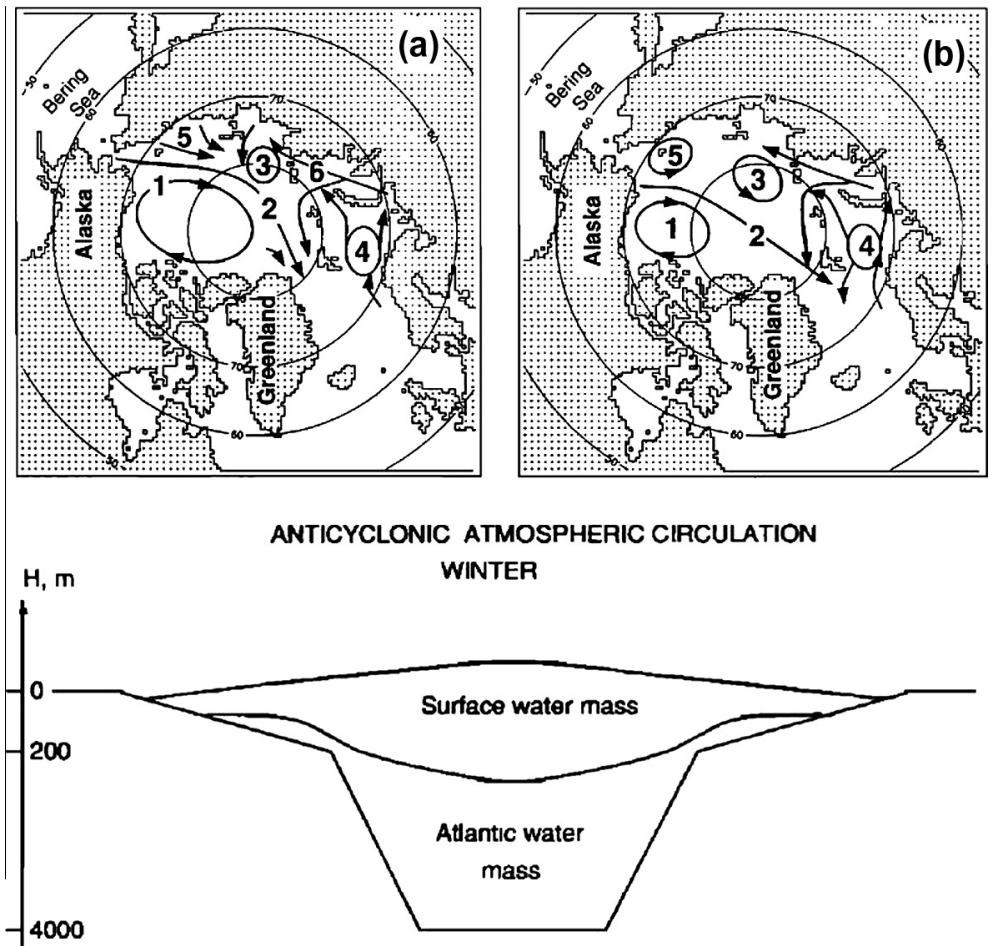

1. Low sea level along the coastlines

2. Upwelling of Atlantic waters and their penetration on the shelf

3. Low river runoff

4. Weak vertical water stratification

5. Increase of heat exchange between atmosphere and ocean

CYCLONIC ATMOSPHERIC CIRCULATION

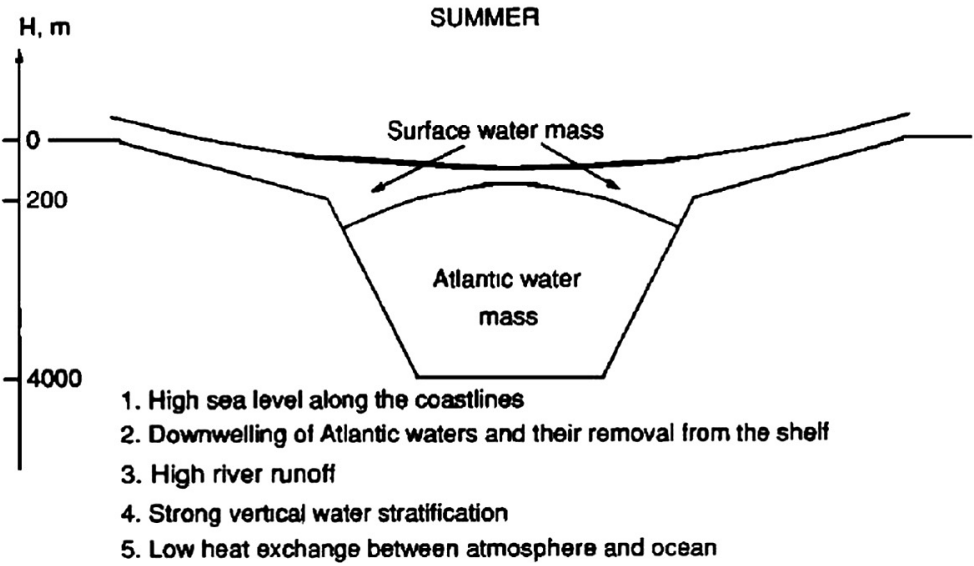

SUMMER

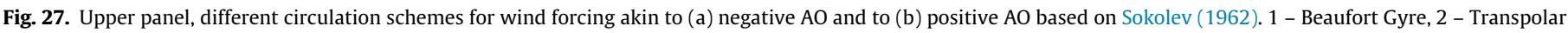

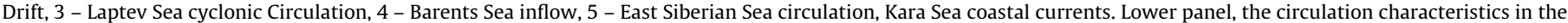
upper in winter and in summer (from Proshutinsky and Johnson, 1997).

from a climatic perspective, then becomes - Would a change in the wind forcing be able to affect, heighten or weaken, the thermohaline processes transforming the water masses, or are their strength determined independently? - That is, would the heat given up by the Arctic Ocean to the atmosphere be the same, if the circulation and exchanges were intensified by changing atmospheric forcing, and the entering water would return less transformed compared to a weaker exchange?

The model used by Proshutinsky and Johnson (1997) was a depth integrated barotropic model, which did not differentiate the vertical stratification and could not represent a circulation varying in depth. This is but one of a large number of models and another model could have given a different result. To better compare the performance of the different models the Arctic Ocean Modelling Intercomparison Project (AOMIP) was started in 2001, where different models are compared with each other and with observations. Models are run with the same forcing and with similar set ups to improve their skill. An introduction to the goals and results of AOMIP is given by Proshutinsky et al. (2011).

\section{Transports}

The exchanges between the Arctic Ocean and the rest of the world ocean have been studied intensively during the last decade. In the Nordic Seas, the Barents Sea and Fram Strait this work has 
largely been conducted within the EU programmes VEINS (Variability of Exchanges in the Northern Seas) and ASOF-N (Arctic Subarctic Ocean Fluxes) and continued in the DAMOCLES (Developing Arctic Observational and Modelling Capabilities for Long-term Environmental Studies) project. The Canadian efforts to study the exchanges through the straits in the Canadian Arctic Archipelago have resulted in monitoring of the transports through Hell Gate and Cardigan Strait (Jones Sound) and through Barrow Strait (Lancaster Sound), and a joint Canadian US programme studies the transport through Nares Strait between Greenland and Ellesmere Island. The transports from the North Pacific through Bering Strait as well as the circulation in the Chukchi Sea and the flow into the Canada Basin have been examined by several Canadian, Japanese and US programmes, e.g., SBE (Shelf Basin Exchanges) and SBI (Shelf Basin Interactions). Reviews of different aspects of the exchanges are found in the books edited by Lewis et al. (2000) and Dickson et al. (2008) and a comprehensive summary of recent observations and estimates is given by Beszczynska-Möller et al. (2011). We may also note that in August 2005 all passages to the Arctic Ocean were monitored by current meter arrays and moorings and comprehensive in situ observations were conducted in all openings. Tsubouchi et al. (2012) utilised this situation to formulate an inverse model for the Arctic Ocean. The freshwater input from rivers and net precipitation was prescribed and volume and salinity (freshwater) balances were applied on the total water column as well as on different layers as they were exchanged between the Arctic Ocean and the surrounding seas. The fluxes through the different passages agree well with those presented below. The largest difference occurs in Davis Strait where a strong outflow of 3.7 Sv is derived. This might be caused by the use of the $640 \mathrm{~m}$ deep Davis Strait as sill depth instead of the shallower, $220 \mathrm{~m}$ sill in Nares Strait farther north.

\subsection{Fram Strait}

The greatest efforts have been put into determining the exchanges though Fram Strait, volume and heat transports as well as the freshwater and the sea ice fluxes. Fram Strait, being the only deep passage, allows both for northward flow of Atlantic Water $(\mathrm{AW})$, Arctic Intermediate Water (AIW) and Nordic Seas Deep Waters (NDW) in the West Spitsbergen Current into the Arctic Ocean, and southward transports of sea ice and low salinity Polar Surface Water and cooled, freshened "Arctic" Atlantic Water (AAW), upper Polar Deep Water (uPDW) and the deep waters from the Amerasian and Eurasian basins in the East Greenland Current out of the Arctic Ocean. The Fram Strait exchanges carry the largest amount of heat of all passages, partly in the northward flowing warm Atlantic water in the West Spitsbergen Current and partly in the southward transport of cold Polar Surface Water and the export of latent heat (cold) as sea ice in the East Greenland Current. The total inflow and outflow are also larger than those through the other passages. Only the inflow over the Barents Sea might be of comparable magnitude.

Both currents are largely barotropic, the West Spitsbergen Current more so than the East Greenland Current. They appear to follow the bottom topography and comprise meandering flows, shallower baroclinic eddies as well as barotropic vortices extending to the bottom. The West Spitsbergen Current is augmented by a second, baroclinic, branch that flows northward along the Mohn Ridge on the western side of the Lofoten Basin and joins the West Spitsbergen Current in Fram Strait (Walczowski and Piechura, 2006). A strong recirculation of the West Spitsbergen Current water masses, especially from the western branch, takes place in Fram Strait. Although the barotropic eddies appear to be attached to bathymetric features, they suddenly start to migrate, mostly toward the west. The recirculation may in fact largely consist of barotropic eddies that move westward to eventually join the East Greenland Current (Fahrbach, 2006; Schauer et al., 2008).

During the VEINS-ASOF-DAMOCLES period a massively instrumented current meter array was, and still is, deployed in Fram Strait, measuring the volume exchanges, the heat transport and the freshwater flux in the water column as well as the ice export in the East Greenland Current (Fahrbach et al., 2001; Schauer et al., 2004). The upper panel in Fig. 28 shows the mooring positions up to 2006 and the average temperature and velocity distributions on the section for 2002-2003 based on the mooring observations, while the lower panel gives the total southward and northward volume and heat transports as well as the net exchanges. The array, covering the main part of the strait, was extended by adding moorings with ADCPs (Acoustic Doppler Current Profiler) and upward looking sonars on the Greenland shelf to measure the ice draft in the East Greenland Current. In the connection with the yearly exchange of the moorings, hydrographic sections were occupied across the strait, sometimes more than once a year.

The transports show large variability on almost all time scales, but there is an annual cycle indicating larger transports during winter. The mean total northward and southward transports were initially determined to around $11 \mathrm{~Sv}$ and $13 \mathrm{~Sv}$ respectively with a variability of 5 Sv (Schauer et al., 2004; Fahrbach, 2006) (Fig. 28). The transport of Atlantic water, warmer than $1^{\circ} \mathrm{C}$, comprises about $50 \%$ of the northward flow (Schauer et al., 2008). The northward flow in the two West Spitsbergen Current branches is presently estimated to $1.8 \mathrm{~Sv}$ with $1.3 \mathrm{~Sv}$ of Atlantic water warmer than $2{ }^{\circ} \mathrm{C}$ in the eastern branch and $4.9 \mathrm{~Sv}$ with $1.7 \mathrm{~Sv}$ of Atlantic water in the off-shore branch, giving a total northward flow of $6.6 \mathrm{~Sv}$ (Beszczynska-Möller et al., 2012). The southward flow in the East Greenland Current is larger, 8.6 Sv, giving a net outflow of $2.0 \mathrm{~Sv}$ but with large variability, $\pm 2.7 \mathrm{~Sv}$ (Beszczynska-Möller et al., 2011). The reduction in the total north and south transports between the estimates by Schauer et al. (2004) and Fahrbach (2006) and those given by Schauer et al. (2008) and Beszczynska-Möller et al. (2011) could possibly be due to the addition of two moorings in the central part of the strait, which allows for a better resolution of the barotropic eddies and the recirculation in the strait (see e.g. the positions of the moorings in the upper part of Fig. 28).

The total northward and southward transports have also been determined from geostrophic calculation on the ASOF and VEINS sections as well as on other historical sections across Fram Strait. The results differ, as expected, from the transports obtained from the direct current measurements (Rudels et al., 2008). The geostrophic transports are smaller, but not greatly so, and the net southward transport was found to be somewhat larger than that determined from the current meter array. This is likely due to an underestimate of the barotropic component in the inflowing West Spitsbergen Current.

The exchanges through Fram Strait have been modelled by several groups, e.g. Maslowski et al. (2004), Fieg et al. (2010) and Aksenov et al. (2010a,b). Especially the volume fluxes obtained by Maslowski et al. (2004), northward $6.40 \mathrm{~Sv}$, southward $8.73 \mathrm{~Sv}$ and net $2.37 \mathrm{~Sv}$, are very close to the latest numbers obtained from the mooring array in Fram Strait.

The northward heat, or rather temperature, transport in the Atlantic water increased significantly during the ASOF years (2002-2005) as compared to the VEINS years (1997-2000), from around 30 to almost 46 terawatt (Fahrbach, 2006; Schauer et al., 2008) (Fig. 28). This was mainly due to the arrival of pulses of warmer water to Fram Strait from the south. The highest temperatures were recorded in 2006 after which a slight decrease has been observed (Beszczynska-Möller et al., 2012; Dye et al., 2012). Schauer and Beszczynska-Möller (2009), using a stream tube model with a balanced volume exchange, estimated the mean heat transport to 

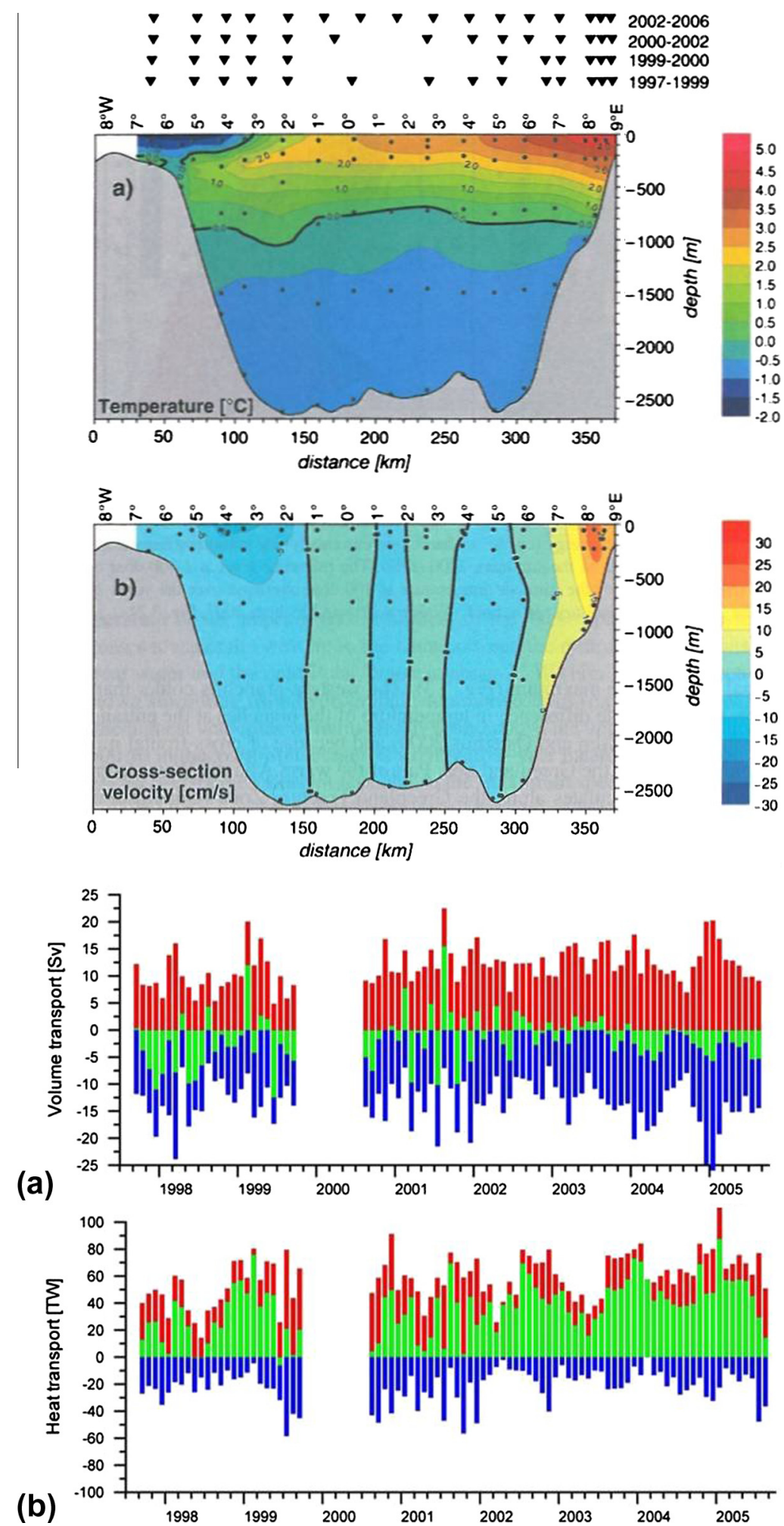

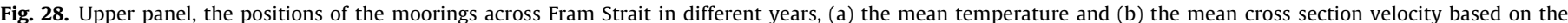

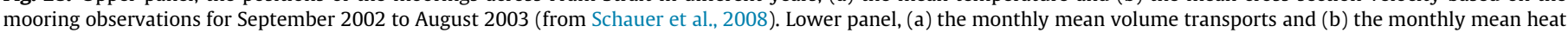
transports 1997-2006. Red northward transports, blue southward transports, green net transports (from Fahrbach, 2006).

$36 \pm 6$ TW for the period 1997-2009. It has been possible to trace several of these inflows to south of the Greenland-Scotland Ridge (Karcher et al., 2003; Holliday et al., 2008). The warm inflows have also been followed along the Eurasian continental slope, the warm pulse of 1998-2002 being observed in 2004 at the NABOS moorings north of the Laptev Sea (Dmitrenko et al., 2008a,b; Polyakov et al., 2005) and by comparison between models and observations (e.g. Karcher et al., 2011) and their possible influence on the Arctic Ocean ice cover has been examined (Polyakov et al., 2010, 2011, 2012a). 
The strong recirculation in Fram Strait makes it difficult to assess how much of the Atlantic water and how much of the AIW and NDW actually enters the Arctic Ocean. Much becomes mixed into the outflowing Arctic Ocean intermediate and deep water masses. The Rossby radius is small and there is no horizontal correlation between the individual moorings, opening for the possibility of aliasing. The Arctic Ocean deep waters that pass through Fram Strait and flow along the Greenland slope are considerably colder and less saline than they are in the Arctic Ocean, indicating mixing with NDW and AIW from the Nordic Seas, thus implying a recirculation of these waters (Rudels et al., 2005). That Atlantic water recirculates in Fram Strait was noticed already by Ryder (1891-1892) and Nansen (1902).

One way to eliminate, or at least reduce, the effects of the recirculation on the exchange estimates is to compute the net transports in different temperature intervals, either for the entire strait or for different parts of the strait (Mauritzen et al., 2011; Beszczynska-Möller et al., 2012). It is found that for temperatures above $2{ }^{\circ} \mathrm{C}$ there is a net inflow in all temperature classes and the mean temperature for the $3.2 \mathrm{~Sv}$ that enter the Arctic Ocean lies between $3.0^{\circ} \mathrm{C}$ and $3.5^{\circ} \mathrm{C}$. Below $2{ }^{\circ} \mathrm{C}$ there is a net outflow in all temperature classes and the $5.2 \mathrm{~Sv}$ that leave the Arctic Ocean have a mean temperature between $-1.0^{\circ} \mathrm{C}$ and $-0.5^{\circ} \mathrm{C}$. The implied cooling, by whatever processes, must occur in the Arctic Ocean.

The ice export from the Arctic Ocean through Fram Strait has been measured for more than a decade. The estimate of the transport has not changed dramatically over this period and it is not much different from earlier assessments. Between 0.08 and $0.09 \mathrm{~Sv}$ of freshwater is transported as sea ice southward through Fram Strait. This is somewhat less than the river runoff of $\sim 0.1 \mathrm{~Sv}$ to the Arctic Ocean suggesting that only a small fraction of the river runoff enters the water column. However, no direct coupling between river runoff and ice export can be made. There are other sources of freshwater, e.g. net precipitation, inflow of less saline water in the Norwegian Coastal Current, and the inflow of low salinity Pacific water through Bering Strait. The extent and the thickness of the Arctic Ocean sea ice cover have decreased during the last 30 years and dramatically so in the last 10 years, but no clear effect of the smaller ice storage in the Arctic Ocean on the ice export through Fram Strait has been documented (Spreen et al., 2009). One possible explanation is that the thinner ice cover allows the ice drift speed to increase, keeping the volume flux more or less constant.

The different sources of freshwater, runoff and net precipitation (meteoric water) and ice melt and ice formation (negative ice melt) can be determined from tracers like ${ }^{18} \mathrm{O}$ and/or Deuterium $\left({ }^{2} \mathrm{H}\right)$ (Östlund and Hut, 1984). The transports of liquid freshwater and sea ice can then be estimated, either using velocities obtained from moorings or estimated from hydrographic sections using geostrophy, or by deducing the age of the water, or its residence time, from tracer observations. Östlund and Hut (1984) used the tritium $\left({ }^{3} \mathrm{H}\right)$ injected into the ocean from the nuclear tests in the 1960s to determine the age of the upper layer in the Arctic Ocean. Assuming this layer to be well mixed horizontally they computed the export of sea ice and freshwater, including the freshwater entering through Bering Strait, to the North Atlantic. The different components of the freshwater transport based on observations from Ymer 1980 are shown in Fig. 29. Östlund and Hut also estimated the combined volume flux of upper layer water through Fram Strait and the Canadian Arctic Archipelago. Their results, 2.9 Sv of upper layer water and a total freshwater export of $0.29 \mathrm{~Sv}$ are similar to the other existing estimates. Their estimated ice export $0.18 \mathrm{~Sv}$ appears, however, too large.

Schlosser et al. (1994) used the tritium/ ${ }^{3} \mathrm{He}$ ratio to better determine the age of the upper layer water. They found that the age of the water increased from 1 year at the Barents Sea continen- tal slope to 5 years over the Gakkel Ridge. The deeper halocline waters over the Gakkel Ridge were still older, about 15 years. The assumption of an horizontally well mixed upper layer in the Arctic Ocean does not seem to hold. This is evident also from other parameters. To date the estimates of liquid freshwater export using tracers and using direct current measurements do not agree. The direct observations of the freshwater flux suggest it to be $1 / 3$ to 2/3 of the ice export (Aagaard and Carmack, 1989; Holfort et al. 2008; Rudels et al., 2008), while the ${ }^{18} \mathrm{O}$ and other tracer analyses indicate that the exported liquid fraction through Fram Strait could be as large, or even larger, than the ice export (Meredith et al., 2001; Rabe et al., 2009, 2013). However, in these estimates the ice export is determined as how much negative melt water is present, or rather absent, from the water column. Since the observations are made in Fram Strait, only the ice formed from the meteoric water leaving through Fram Strait is accounted for. Ice removed from the meteoric water exiting through the Canadian Arctic Archipelago is not considered. Very little sea ice leaves through the Canadian Arctic Archipelago and this ice also has to pass south through Fram Strait. The extra ice volume could remove the discrepancy between the two methods.

\subsection{The Barents Sea}

The Atlantic water that enters the Barents Sea splits into 3 streams. One flows north into the Hopen Deep west of the Central Bank. In the northern part of the Hopen Deep it splits again. One part turns east, north of the Central Bank, one, smaller part, crosses the sill between Edgeøya and the Grand Bank into the northern Barents Sea and the rest recirculates towards the Norwegian Sea (Tantsiura, 1959; Loeng, 1991; Pfirman et al., 1994). Fig. 30 shows the surface current as drawn by Tantsiura (1959). The Atlantic water is cooled by heat loss to the atmosphere and by intrusions of cold and dense water formed by ice formation and brine rejection over the Central Bank and subsequently sinking down the slopes of the bank into the surrounding depressions (Quadfasel et al., 1992). Part of this water returns to the Norwegian Sea as cold, dense bottom water in the Bear Island Trough. The ice formation over the Central Bank depends upon the strength and temperature of the Atlantic inflow. When the inflow is strong, Atlantic water covers the Central Bank and no cooling to freezing temperatures and no brine-induced convection to the bottom are possible (Quadfasel et al., 1992).

A second stream moves eastward close to the coast. It comprises not only Atlantic water but also the less saline water of the Norwegian Coastal Current, carrying runoff from the Norwegian coast and the low salinity outflow from the Baltic Sea. The continuation of the Norwegian Coastal Current, the Murman Coastal Current follows the coast up to Novaya Zemlya. One part enters the Kara Sea through the strait south of Novaya Zemlya, the Kara Gate, and the rest moves northward along the west coast of Novaya Zemlya to enter the Kara Sea north of the islands. The coastal stream supplies the saline end member of the waters on the Siberian shelves, balancing the river runoff.

The third, main stream flows directly eastward and passes south of the Central Bank into the eastern Barents Sea. The Atlantic water loses heat to the atmosphere and becomes cooler. Precipitation and the encounter with drifting sea ice lead to a freshening of the surface layer. In winter, cooling, ice formation and convection homogenise the upper layer, creating the Barents Sea branch halocline water. Over the shallow polynya areas west of Novaya Zemlya the convection extends to the bottom. The entire water column becomes homogenised, and dense, saline bottom water is produced (Knipovitch, 1905; Nansen, 1906; Midttun, 1985). The ice exported from the polynya eventually melts, either through the arrival of spring or by drifting over warmer Atlantic water forming a low 


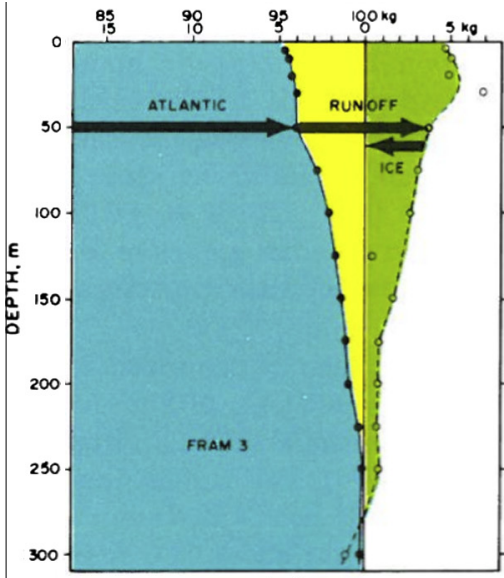

(a)

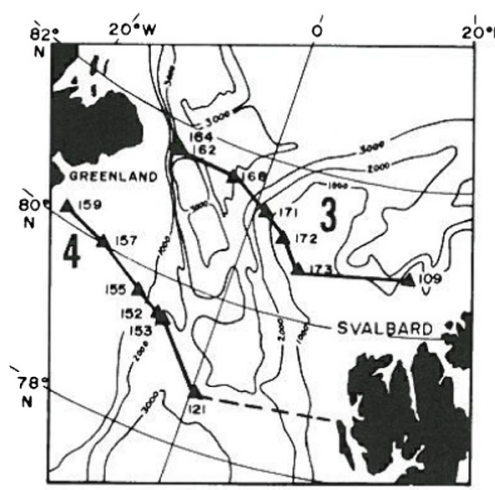

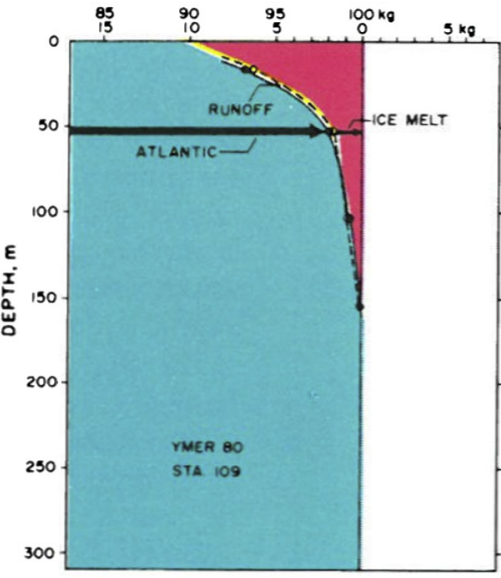

(b)

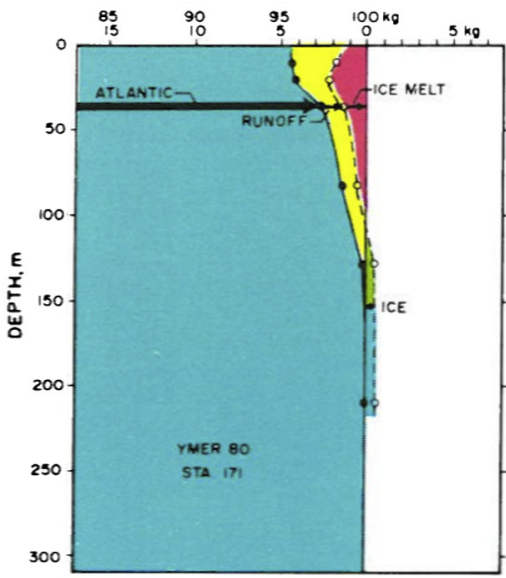

(c)

(a)
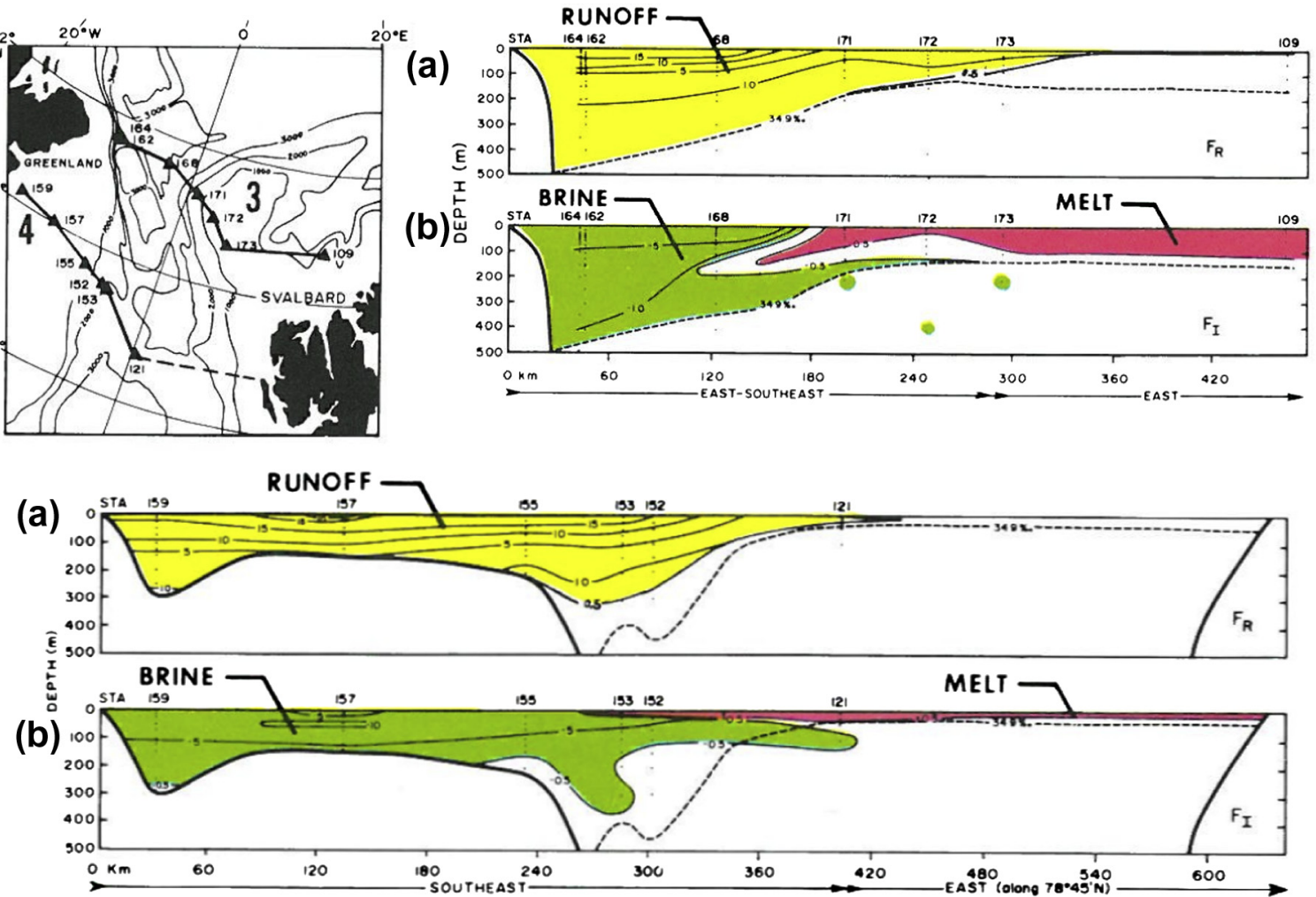

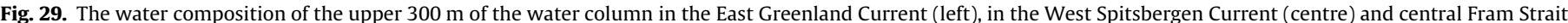

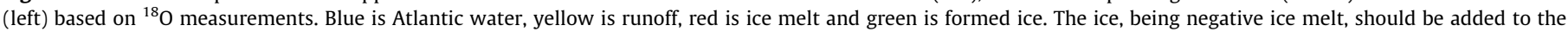
runoff in the East Greenland Current. Lower panel, the distribution of runoff, ice melt and brine on two sections taken by Ymer in 1980 (from Östlund and Hut, 1984).

salinity upper layer. The different layers, the less saline surface layer making up the Barents Sea branch halocline water, the intermediate cooled Atlantic water and the dense brine enriched bottom water all pass between Franz Josef Land and Novaya Zemlya and eventually down the St. Anna Trough into the Arctic Ocean.

The upper layers in the northern Barents Sea are dominated by less saline water that is cooled to freezing temperature in fall and becomes covered by a locally formed seasonal ice cover, which prevents the multi year ice in the Arctic Ocean from drifting into the Barents Sea. Occasionally multi-year ice does penetrate into the Barents Sea before the local ice cover is formed, as in 2003 when multi-year ice was found in Storfjorden in winter. This ice must have drifted into the northern Barents Sea and then into
Storfjorden in late 2002 or early 2003 (Christian Haas, Pers. Comm.; Kwok et al., 2005).

The origin of this less saline upper layer is not clear. It could derive from the Arctic Ocean, or it could be advected from the Kara Sea between Franz Josef Land and Novaya Zemlya, flowing westward in the Persey Current (Fig. 30). A third possibility was mentioned above. Ice formation over the shallow polynya areas leads to a separation into sea ice and saline bottom water, which by subsequent ice melt creates, or at least contributes to maintaining, the low salinity surface water in the northern Barents Sea. Outflows of less saline water from the northern Barents Sea to the Norwegian Sea occur south of Bjørnøya along the Svalbard Bank as a continuation of the Persey Current and south of Svalbard in the East Spitsbergen Current (Tantsiura, 1959). These outflows, however, are 


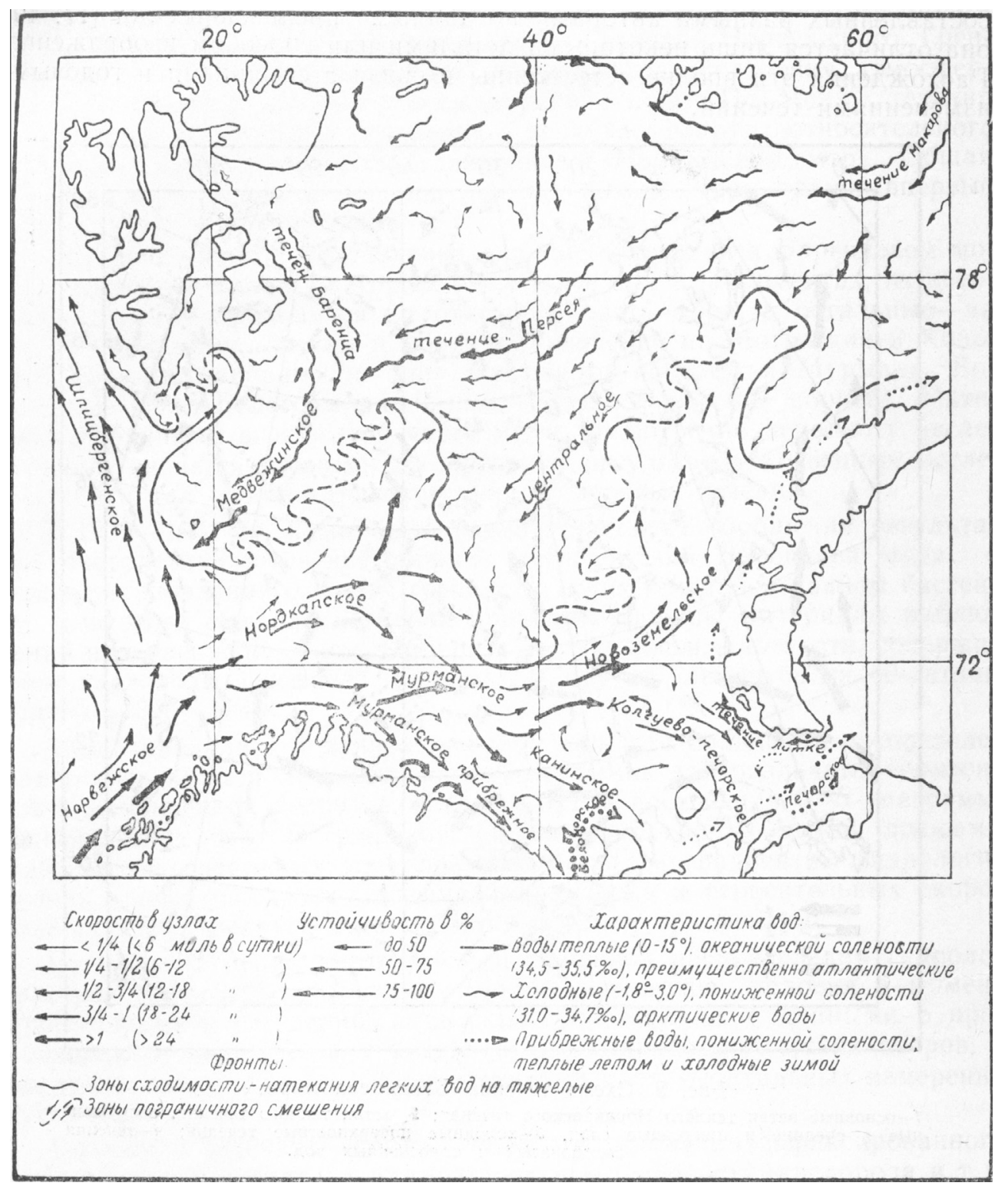

Fig. 30. The surface circulation in the Barents Sea (from Tantsiura, 1959).

caught in the northward moving West Spitsbergen Current and carried towards Fram Strait and the Arctic Ocean.

The most quoted early estimate of the net inflow from the Norwegian Sea to the Barents Sea is the $1.9 \mathrm{~Sv}$ estimated by Blindheim (1989) from a three week long current meter observation in the Bear Island Trough between the Norwegian coast and Bjørnøya, the Barents Sea opening. After this the transport of Atlantic water from the Norwegian Sea into the Barents Sea has been measured around the year by direct current observations since 1997 and the beginning of VEINS, and the measurements have continued during ASOF and DAMOCLES. The transport across the array shows large variations on both shorter and longer time scales. The transport estimates for the Atlantic water have until lately been fairly constant around $1.5 \mathrm{~Sv}$. There is an annual cycle with stronger inflow during winter, less in summer. Net outflows to the Norwegian Sea over extended periods have been observed, especially in spring, when these outflow events can be longer than a month (Ingvaldsen et al., 2004a,b). The inflowing Atlantic water is warm, between $4{ }^{\circ} \mathrm{C}$ and $6{ }^{\circ} \mathrm{C}$ with a mean salinity above 35.05. The temperature and salinity as well as the transports show large inter-annual variability reflecting changes in the waters advected from the south (Skagseth et al., 2008; Dye et al., 2012). Skagseth (2008) analysed the circulation of Atlantic water in the Bear Island Trough and found an inflow of $2 \mathrm{~Sv}$ but also a deep return flow of $0.9 \mathrm{~Sv}$ of cooled, dense water close to Bear Island, giving a net inflow of $1.1 \mathrm{~Sv}$ of Atlantic water. There is also a cold, less dense outflow of $0.3 \mathrm{~Sv}$ higher up on the slope towards Bear Island (Blindheim, 1989).

The transport in the Norwegian Coastal Current to the Barents Sea was not measured in the ASOF and VEINS programmes and the best available estimate at the start of IPY was the $0.7-0.8 \mathrm{~Sv}$ obtained by Aagaard and Carmack (1989) based on the data presented by Blindheim (1989), and also proposed by Rudels (1987) from heat and mass constraints. The salinity of the Norwegian Coastal Current is about 34.4 (Aagaard and Carmack, 1989). Skagseth et al. (2011) have updated the transport in the Norwegian Coastal Current, separating into an almost barotropic flow following the bottom contours at the slope and baroclinic flow extending farther into the deeper part of the trough. They obtained a total transports of $2.6 \mathrm{~Sv}$ of which 1.8 comprised Norwegian Coastal 
Current water with salinity 34.3 and the rest Atlantic water. The estimates for the coastal current were made somewhat farther to the east compared to the standard section in the Barents Sea opening and the question is of the Atlantic water transport of $0.8 \mathrm{~Sv}$ should be added to the $1.1 \mathrm{~Sv}$ obtained by Skagseth (2008) or not. To get the total inflow also the $0.3 \mathrm{~Sv}$ outflow has to be subtracted. In any case the total inflow to the Barents Sea from the Norwegian Sea would then be 3.2-3.3 Sv, substantially higher than the $1.9 \mathrm{~Sv}$ found by Blindheim (1989).

The transport between Franz Josef Land and Novaya Zemlya was measured in 1991-1992, by moored current meters (Loeng et al., 1993, 1997; Schauer et al., 2002b). These observation were recently combined with modelling work (Gammelsrød et al., 2009). The transport was estimated to about 2 Sv, consistent with the moored current observations made in the Bear Island Channel during ASOF/VEINS and also with the earlier current observations in the Bear Island Channel reported by Blindheim (1989). Schauer et al. (2002b) also compared the transports between Franz Josef Land and Novaya Zemlya with those estimated from hydrography and ship mounted ADCP in St. Anna Trough in 1996 and arrived at similar transports. A second yearlong mooring array was deployed between Franz Josef Land and Novaya Zemlya in 2006 and recovered in 2007. Unfortunately the data are still not available.

A smaller fraction of the inflowing from the Norwegian Sea also leaves the Barents Sea between Svalbard and Franz Josef Land, especially in the Victoria Channel, and a substantial part may pass through Kara Gate south of Novaya Zemlya to the Kara Sea. There it will mix with the runoff from $\mathrm{Ob}$ and Yenisey, providing the saline end member of the shelf water, which continues through Vilkiltskij Strait to the Laptev Sea, where it receives the runoff from Lena before it enters the deep Arctic Ocean basins.

The modelling efforts of the transports over the Barents Sea have been large and here we just mention the work by Maslowski et al. (2004) and Aksenov et al. (2010a), which were discussed in relation to Fram Strait. The model by Maslowski et al. gets a similar high $(3.37 \mathrm{~Sv}$ ) net inflow from the Barents Sea as the recent estimate suggests, while the transports $(1.6 \mathrm{~Sv})$ from the Aksenov et al. model more conform to the previous estimates.

\subsection{The Bering Strait}

Bering Strait connects, via the Arctic Ocean, the North Atlantic to the North Pacific Ocean and forms a shortcut between the two opposite poles of the global ocean circulation, the active, deep ventilating North Atlantic and the almost stagnant North Pacific. The transports through Bering Strait are from the North Pacific to the Arctic Ocean, although situations with southward flow do occur in connections with northerly winds. This northward flow, warm in summer, has long been known and DeLong, leading the Jeanette expedition in 1879 , hoped that it carried enough heat to create open water, or at least less severe ice conditions, to allow him to reach the North Pole. This was proved wrong and Jeanette wrecked in the northern East Siberian Sea in 1881.

Sverdrup et al. (1942) considered the inflow from the Pacific Ocean to be small, $0.3 \mathrm{~Sv}$, and regarded the Arctic Ocean as an almost isolated ocean. Russian studies in the mid 20th century (Maksimov, 1945; Fedorova and Yankina, 1964) indicated larger transports, close to $1 \mathrm{~Sv}$. but also a strong seasonal cycle, the transport in winter being about $1 / 3$ of that in summer. The work in the Bering Strait intensified during the 1960s and 1970s and its physical oceanography was summarised by Coachman et al. (1975). The transport through the strait was then estimated to be larger than previously assumed, mostly because no evidence of a seasonal cycle was found in the early direct current observations. The inflow estimates thus ranged between 1 and $1.5 \mathrm{~Sv}$.
The force driving the inflow derives from the higher sea level in the North Pacific that accelerates the water through the narrow channel. This pressure gradient is balanced by bottom friction (Coachman and Aagaard, 1966). Stigebrandt (1984) adopted a more global view and argued that the higher sea level in the North Pacific was due to the less dense upper part of the North Pacific water column compared to that of the North Atlantic. Since the North Atlantic deep water ventilates the deep world ocean, also the North Pacific, a pressure reversal must occur in the water column, the pressure increasing towards the North Pacific on a geopotential surface in the upper part of the water column and decreasing from the North Pacific on a geopotential surface in the lower part. Stigebrandt proposed that this pressure reversal occurred at $1100 \mathrm{~m}$. From the difference in steric heights between the two water columns he then obtained the sea level slope from the North Pacific to the North Atlantic through Bering Strait and estimated the transport induced by this pressure gradient to $1.5 \mathrm{~Sv}$ (Fig. 31). This was consistent with the then existing current measurements as well as with the estimates derived from tracer observations (e.g. Östlund and Hut, 1984). The transport of water vapour by the trade winds across the Isthmus of Panama from the North Atlantic to the North Pacific has been identified as one cause for the less dense water column in the North Pacific (Weyl, 1968). The transfer of low salinity Pacific water through Bering Strait is the route by which most of the freshwater, but also the salt exported in the North Atlantic Deep Water returns to the North Atlantic (Wijffels et al., 1992).

Continued observations in the 1970s and 1980s eventually vindicated the early Russian results. A seasonal variation in the transport was confirmed. The inflow in summer was estimated to $1.2 \mathrm{~Sv}$, while the inflow in winter was reduced to $0.4 \mathrm{~Sv}$, the mean being assessed to $0.8 \mathrm{~Sv}$. (Coachman and Aagaard, 1988; Roach et al., 1995). The observation programme in the Bering Sea continued and was intensified in the 1990s and 2000s. The ideal distribution of the current observations would be to have one mooring with $\mathrm{ADCP}$ and temperature and salinity recorder in the strait on each side of the Diomedes Island to get the transports from both the eastern and the western channels and one mooring close to the Alaskan coast to observe the inflow in the Alaskan Coastal Current. Most of the years especially the western mooring has not been deployed and the eastern mooring has then been moved to a fourth position north of the strait to monitor the transports through both channels.

From current measurements between 1990 and 2004 Woodgate and Aagaard (2005), found that the low salinity Alaskan Coastal Current carries a large amount of freshwater, mainly originating from the Yukon River, into the Arctic Ocean. This inflow had previously been neglected and its contribution would increase the freshwater input through Bering Strait by 0.01-0.02 Sv. (relative to 34.8 ) or by $20 \%$. The mean inflow has also shown a small increase, from 0.8 to $1.0 \mathrm{~Sv}$ over the last years. The time series is, however, too short to determine if this is a trend or just variability.

Woodgate et al. (2005b) observed that the Pacific water leaves the Chukchi Sea from 4 locations: (1) through Long Strait into the East Siberian Sea, (2) along the Herald Canyon west of the Chukchi Borderland into the Canada Basin, (3) through the Central Gap east of the Chukchi Borderland into the Canada Basin and (4) along the Barrow Canyon close to the Alaskan coast and shelf. The export of Pacific water to the East Siberian Sea is largely compensated in volume, if not in salt, by the eastward flowing East Siberian Coastal Current (Woodgate et al., 2005b).

Steele et al. (2004) studied the fate of the Alaskan Coastal Current water and the warm Bering Sea Summer water (BSSW) for different forcing regimes, i.e. for different Arctic Oscillation (AO) states. With the AO strongly positive a part of the Alaskan Coastal Current stayed at the shelf break and followed the North American 


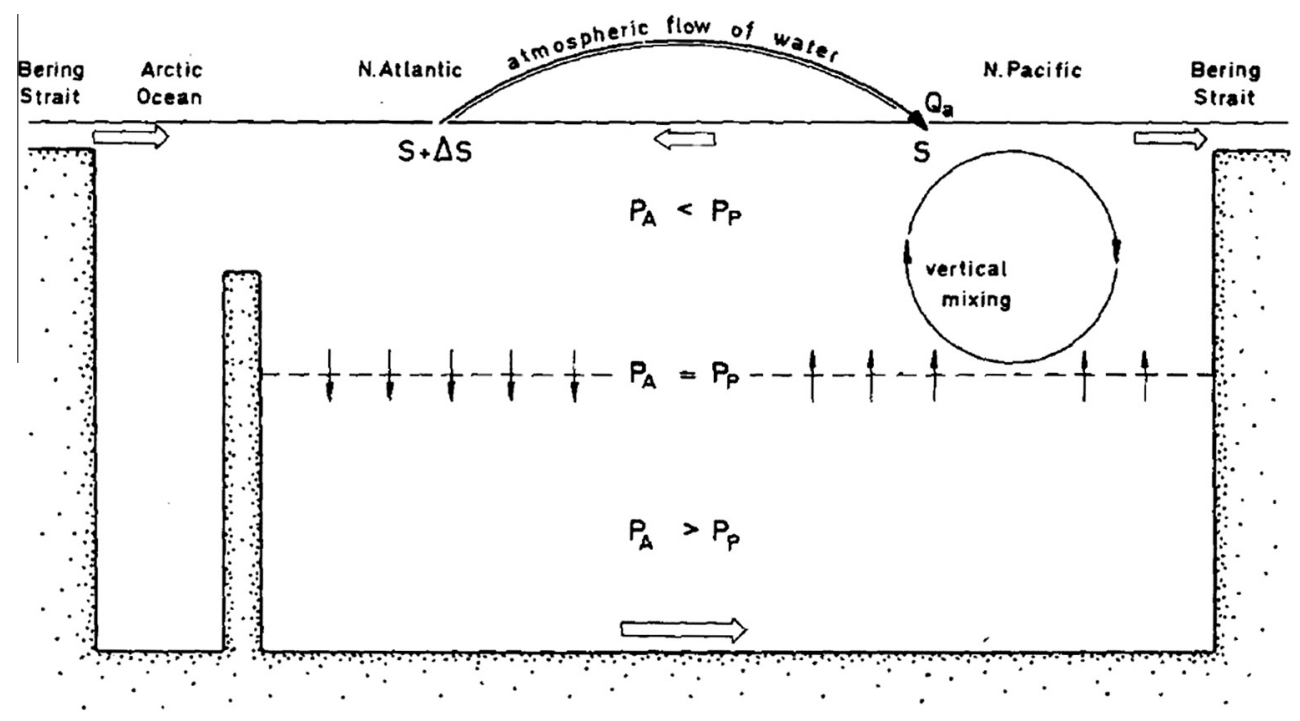

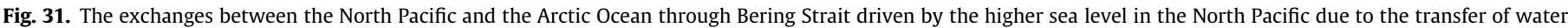

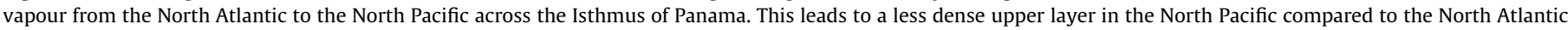

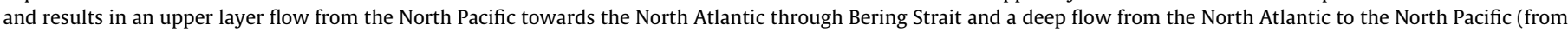
Stigebrandt, 1984).

continent towards Greenland. The rest of the Alaskan Coastal Current water drifts along the slope westward and joins the Bering Sea Winter Water (BSWW) that enters the Canada Basin east of the Chukchi Borderland. These two waters then enter a diminished Beaufort Gyre, while the rest of the BSSW enters the Canada Basin west of the Chukchi Borderland and continues in the Transpolar Drift towards Greenland. During a negative AO state the BSSW mostly enters Canada Basin west of the Chukchi Borderland and becomes trapped, together with Alaskan Coastal Current water drifting westward along the continental slope, in an expanded Beaufort Gyre. Little BSSW then enters the Transpolar Drift, which is mainly supplied by water from the Siberian shelf seas. The part of the Alaskan Coastal Current that stays close to the continent would be obstructed by the stronger Beaufort Gyre and mainly enter the western channels of the Canadian Arctic Archipelago and not reach as far east as Greenland (Steele et al., 2004). The BSSW forms a part of the Pacific halocline found in the Canada Basin and at times in the Makarov Basin.

Much of the denser Pacific water leaving the Chukchi shelf forms a subsurface boundary current that flows eastward along the upper part of the Chukchi and Alaskan continental slope. The main contribution comes from the outflow in the Barrow Canyon, but also water from the Herald Canyon joins the boundary current (Pickart, 2004; Pickart et al., 2005). This flow was monitored within the SBI programme for two years (2002-2004) by a high resolution mooring array with MacLane profilers giving 4 sections a day. The observed flow in the boundary current was weaker than anticipated, $0.13 \mathrm{~Sv}$. This could partly be explain by the adverse northeasterly winds that dominated over the mooring area and if that was taken into account the transports increased to $0.32 \mathrm{~Sv}$ (Nikolopoulos et al., 2009). It nevertheless indicates that much of the Pacific water, which leaves the Chukchi shelf does not join the boundary current. It could from the Herald Canyon be directly incorporated in the transpolar drift as indicated by Steele et al. (2004), or it could leave the shelves by forming eddies.

Pickart et al. (2005) showed, based on observations from the mooring array that the subsurface, mainly anticyclonal, eddies observed in the Canada Basin (Shirshov, 1944; Hunkins, 1974; Newton et al., 1974; Belyakov and Volkov, 1980) could be created by instabilities in the boundary current and the detached eddies entering the Canada Basin would eventually feed the lower, denser part of the Pacific derived halocline. Spall et al. (2008) modelled the eddy formation in the shelfbreak boundary current and found that eddies were created by baroclinic instability in the current.

It has also been suggested that dense water from the lee polynyas on the Chukchi shelf could directly enter the Canada Basin and form eddies (Chapman and Gawarkiewicz, 1997; Gawarkiewicz et al., 1998; Gawarkiewicz, 2000). However, model studies have shown that the waters and eddies formed on the shelf become trapped at the shelf break/slope and would join the boundary current (Chapman and Gawarkiewicz, 1997; Winsor and Chapman, 2002, 2004). There a new generation of eddies could form and enter the Canada Basin as proposed by Pickart et al. (2005). The boundary current might be reversed by upwelling conditions, forcing the underlying Atlantic water higher up on the slope and creating a sea level slope rising from the shelf towards the interior of the basin, driving the boundary current westward along the slope (Pickart et al., 2005).

The difference in the ratios of Nitrate to Phosphate, N/P, between the Pacific water and the Atlantic water has in the last decade been used to identify the fraction of Pacific water present in water column. The differences in N/P ratios are shown in Fig. 32.

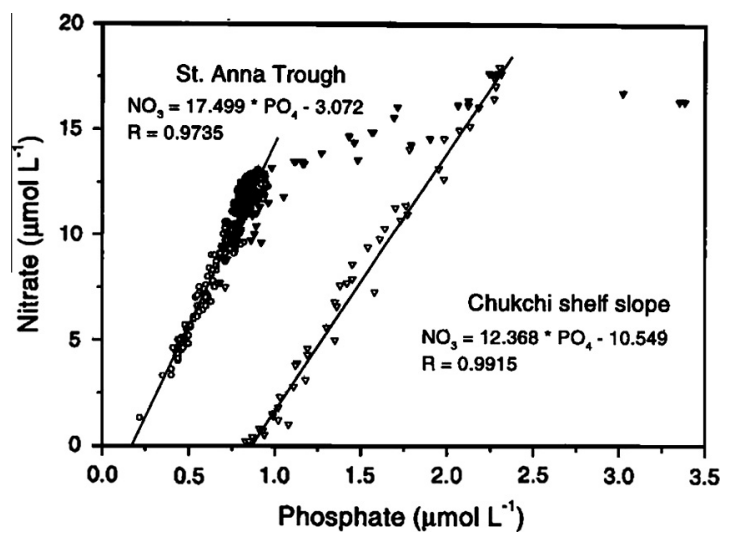

Fig. 32. The different Nitrate and Phosphate ratios in Atlantic and Pacific waters used to determine the Pacific water fraction in the Arctic Ocean upper waters (from Jones et al., 1998). 
This has mostly been done for the upper layers, separating runoff and ice melt from Pacific water (Jones et al., 1998). These studies of the Pacific water distribution have shown that the Pacific water dominates in the surface water of the Canada Basin, in the straits in the Canadian Arctic Archipelago and at the continental shelf and slope north of the North American continent, often extending beyond Greenland into Fram Strait and following the East Greenland Current along the east coast of Greenland (Jones et al., 2003; Jones and Anderson, 2008). Its extension from North America into the Makarov Basin and the Amundsen Basin largely varies with the state of the AO. With strong positive AO it is confined to the continent, while with weakly positive or negative AO it extends deeper into these basins, reaching the North Pole in the Amundsen Basin (Morison et al., 2006).

\subsection{Canadian Arctic Archipelago}

The Canadian Arctic Archipelago is the most inaccessible of the passages between the Arctic Ocean and the world ocean. It consists of three major straits, from east to west Nares Strait, Jones Sound and Lancaster Sound, which all open to Baffin Bay. There are constrictions farther upstream, but they all belong to these channel systems. The northern and southern parts of Nares Strait are named the Kennedy Channel and Smith Sound respectively, the Cardigan Strait and Hell Gate are part of the Jones Sound and the Wellington Channel and the Barrow Strait both continue into Lancaster Sound. Only the small Bellot Strait opens to Regent Inlet and reaches the Lancaster Sound east of the Barrow Strait. The Fury and Hecla Strait allows water to enter the Hudson Bay and then continue via Hudson Strait and Labrador Sea to the North Atlantic. This flow is, however, believed to be very small. During the first part of the 1900s the transports through the Canadian Arctic Archipelago were assumed small. In the volume balance given by Sverdrup in the Oceans the fluxes through the Canadian Arctic Archipelago are ignored altogether and the waters in Baffin Bay were supposed to derive from the Labrador Sea. A local renewal of the Baffin Bay deep waters was also considered possible (Sverdrup et al., 1942).

Baffin Bay is an enclosed bay between Greenland and Baffin Island with Ellesmere Island and Devon Island to the north. It is ice covered in winter and it communicates with the Arctic Ocean through the channels in the Canadian Arctic Archipelago and with the North Atlantic through the $640 \mathrm{~m}$ deep Davis Strait. Its main hydrographic features were known already in the 1930s, largely based on the Godthaap expedition (Riis-Carstensen, 1936; Kiilerich, 1939), and the Marion and General Green cruises (Smith et al., 1937). The temperature and salinity distributions on a section along the axis of Baffin Bay taken by Godthaap in 1928 are shown in Fig. 33. The upper part comprises a low salinity water mass, homogenised in winter by ice formation, brine rejection and convection. In summer the limit of the convection is indicated by a cold $\left(-1.6^{\circ} \mathrm{C}\right)$ layer with a salinity of 33.6-33.7 at $100 \mathrm{~m}$. In summer the surface salinities become much lower due to the melting of sea-ice and an inflow of less saline Polar water from the Archipelago. Below the cold upper layer the temperature and salinity increase with depth and a more than $500 \mathrm{~m}$ thick layer with temperatures above $0{ }^{\circ} \mathrm{C}$ is encountered. This is an Atlantic layer, similar to that found in the Arctic Ocean, but the passages in the Archipelago are too shallow to allow the Arctic Atlantic water with $\theta>0{ }^{\circ} \mathrm{C}$ to enter Baffin Bay. The warm layer must therefore enter Baffin Bay from the south, through Davis Strait. Its salinity is comparatively low, 34.5, and it comprises Irminger Current water, which has mixed extensively with Polar water from the East Greenland Current before it continues in the West Greenland Current into Baffin Bay.

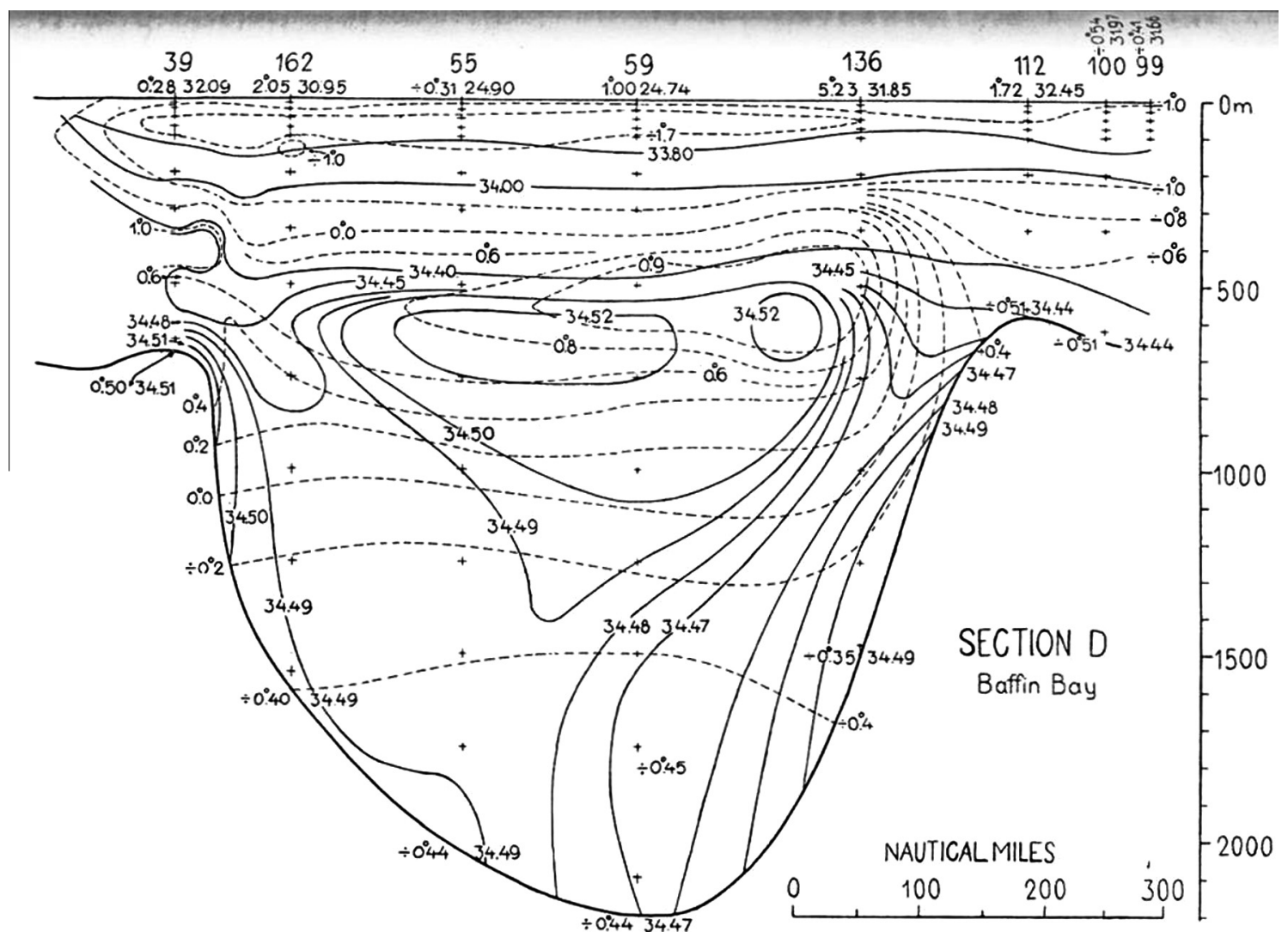

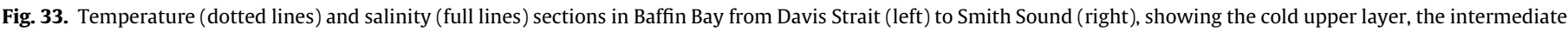
temperature and salinity maxima and the cold slightly less saline bottom water (from Riis-Carstensen, 1936). 
The deep and bottom waters in Baffin Bay are cold and the bottom water has distinct characteristics with temperature $-0.5{ }^{\circ} \mathrm{C}$ and salinity 34.45 . Its origin has been open to discussion. Sverdrup et al. (1942) assumed that it was formed by mixing between local convection and water from the Labrador Sea, and local convection has also been suggested by Bourke et al. (1989, 1991). The alternative explanation is advection from the Arctic Ocean. Bailey (1956) noticed that the characteristics of the Baffin Bay Bottom Water were similar to those found at $250 \mathrm{~m}$ depth in the Beaufort Sea and proposed that an advection of this water takes place through Nares Strait, the deepest channel in the Canadian Arctic Archipelago with a sill depth of $230 \mathrm{~m}$. This explanation was accepted by Rudels et al. (2004), who suggested that a part of the lower halocline in the Canada Basin, which is derived from the Barents Sea inflow branch, will exit through Nares Strait. The lower halocline water is located higher in the water column north of Greenland than in the Beaufort Sea and it could more easily pass over the deeper sill in Nares Strait.

One interesting detail is that in this depth range the temperature increases with depth in the Arctic Ocean and the water entering the deeper layers of Baffin Bay must pass through the warm Atlantic layer in Baffin Bay to renew the bottom water. The entrainment must then be small, because if the entrainment is large, warm and less dense water will be added and the density decreases. To compensate for the density decrease and allow the entering water to sink to the bottom its initial density must be higher. This would imply an inflow of denser, but also warmer, water, leading to different characteristics of the Baffin Bay Bottom Water than those observed (Rudels et al., 2004). A substantial fraction of the denser water that enters from the Arctic Ocean mixes with and cools the Atlantic layer and based on the temperature difference of the Atlantic layer in the West Greenland Current just north of Davis Strait and in the northern part of Baffin Bay Rudels (1986b) estimated that 5/6 of the volume of the Atlantic layer in Baffin Bay derives from the Arctic Ocean inflow.

In a simple model, applying rotational control on the low salinity outflow, Stigebrandt (1981) concluded that more Polar water would exit through the Canadian Arctic Archipelago than through Fram Strait. This is due to the existence of more openings to carry the transport through the Archipelago. Rudels (1986b), using a similar approach both on the straits in the Archipelago and on Davis Strait, combined with salt and mass balances in Baffin Bay, estimated the upper layer outflow to $0.7 \mathrm{~Sv}$. To this a $0.3 \mathrm{~Sv}$ inflow of denser water was added to explain the properties of the Atlantic and deeper layers. Steele et al. (1996), computing the geostrophic transports between different parts of the Arctic Ocean, estimated the outflow through the Canadian Arctic Archipelago to 0.56 Sv.

A large current measurement programme was initiated by Bedford Institute of Oceanography in Baffin Bay in the 1980s. A current meter array was deployed for several years, mostly at the sill in Davis Strait but in some years farther north in Baffin Bay. The transport estimates from these measurements indicate a net southward flow of about 2.4 Sv through Davis Strait (Tang et al., 2004; Cuny et al., 2006). This agrees with later observations based on a current meter array at the sill in Davis Strait combined with hydrographic sections, several of them obtained by gliders (Curry et al., 2011; Beszczynska-Möller et al., 2011).

Direct current measurements in the Canadian Arctic Archipelago have been difficult to accomplish. The areas are remote and largely ice covered, the tidal motions are strong and the proximity to the magnetic North Pole makes conventional direction finding methods practically useless. However, in recent years new techniques have been developed. One method involves measuring the magnetic heading and adjusting for the varying declination with measurements from the Natural Resources Canada geomagnetic observatory in Resolute (Hamilton, 2001). Another method applies torsionally rigid moorings, which are deployed in such a manner that the position and orientation of the anchor are known, and the flow direction can then be measured relative the orientation of the anchor (Melling et al., 2008).

These new developments have lead to the launching of current observation programmes in all three channels: Cardigan Strait and Hell Gate (Jones Sound); Barrow Strait (Lancaster Sound) and in the Kennedy Channel (Nares Strait). The first two passages have already been monitored several years, while in the Kennedy Channel instruments were deployed first 2004. The planned recovery from the ice in spring 2005 had to be abandoned because of a severe storm and the recovery was postponed to fall 2006 and carried out from ship (Münchow et al., 2006).

The observations from Hell Gate showed strong flow in the entire water column $\left(0.20 \mathrm{~ms}^{-1}\right.$ at $\left.81 \mathrm{~m}\right)$ with little temporal variations. At the same depth in the Cardigan Strait the maximum velocity was somewhat higher and the temporal variations in velocity were larger with occasional reversals of the flow direction. The variations detected at Hell Gate had similar periods but much smaller amplitudes. The mean transport through the two straits was estimated to $0.3 \mathrm{~Sv}$ (Melling et al., 2008).

The eastward transports through Barrow Strait to Baffin Bay showed much larger and irregular temporal variations. The Barrow Strait is wide and the flow towards Baffin Bay does not extend over the entire strait but is restricted to the southern $2 / 3$ of the passage. In the northern part a westward flow was observed. The highest velocities were found in the upper parts and related to a low salinity eastward flow of Polar water in the south and a westward flow of low salinity water in the northern part, presumably due to ice melt and to runoff and melting from nearby land. In the deeper parts warmer water from Lancaster Sound was observed, indicating a slower westward flow in the deeper layers. This transport probably does not reach the Arctic Ocean but recirculates and returns to Baffin Bay. Assuming that the current measurements in winter are representative for the southern 2/3 of Barrow Strait they should be reduced to $55 \%$ to represent the same area in summer. The mean flow through Barrow Strait over the observation period was estimated to about $0.7 \mathrm{~Sv}$ (Prinsenberg and Hamilton, 2005).

In a more recent work Peterson et al. (2012) revised the earlier transport estimate downward to $0.47 \mathrm{~Sv}$. The annual and seasonal variability is, however, large. They concluded that the transport depended upon the wind field. If the wind in the Beaufort Sea was southwesterly water would be forced towards the Archipelago and the sea level would rise in the western parts of the channels, increasing the along strait sea level slope. This results in higher transports. The opposite situation would lower the transports. In the average situation the sea level slopes from the Arctic Ocean to Baffin Bay, which is a part of the general slope in sea level from the North Pacific to the North Atlantic.

The other important passage is Nares Strait, where ship mounted ADCP measurements at a crossing during the deployment of the mooring array indicated a southward flow of $0.9 \mathrm{~Sv}$ (Münchow et al., 2006). The transports estimated from the direct current measurements were slightly lower, 0.57 (Münchow and Melling, 2008), and 0.47 Sv if also geostrophy is considered (Rabe et al., 2010). In these later estimates the upper $25 \mathrm{~m}$ and $35 \mathrm{~m}$ respectively were not taken into account.

The total transport through the passages of the Canadian Arctic Archipelago would then range between 1.4 and $1.8 \mathrm{~Sv}$. This is somewhat less than estimated for the outflow through Davis Strait. Considering the shallowness of the straits in the Archipelago and the overall mass budget of the Arctic Ocean, the lower values, based on observations in the Archipelago, appear more reasonable. The salinity of the water that passes through the Canadian Arctic Archipelago is low, supporting the view that most of the liquid 
freshwater export from the Arctic Ocean takes place here rather than in Fram Strait.

The importance of the sea level slope and the generally higher water level in the Arctic Ocean was noticed in the model work by Kliem and Greenberg (2003) and the effect of the variation in sea level slope was studied by Houssais and Herbaut (2011), who suggested that the variations in transports through Lancaster Sound were controlled by the sea level in the Beaufort Gyre, while the Nares Strait was more influenced by changes in the sea level in Baffin Bay and in the Labrador Sea. Similar conclusions was drawn by McGeehan and Maslowski (2012). However, they found that in spite of being controlled by different sea level variations the strong correlation between the outflows suggested that the variability was largely dependent upon, albeit different, coupled aspects of the $\mathrm{NAO}$, the wind stress curl in the Beaufort Sea and the cooling in the Labrador Sea. The mean transports determined by McGeehan and Maslowski (2012) for the two channels were 0.77 Sv, for Nares Strait and 0.76 Sv for Lancaster Sound. The freshwater transport through Lancaster Sound was, however, more than 4 times as large as that through Nares Strait. The transports estimates given by Houssais and Herbaut (2011) were substantially larger, between 1.05 Sv and 1.35 Sv in Lancaster Sound and 1.3 Sv in Nares Strait, while the outflow through Davis Strait was estimated to $2.9 \mathrm{~Sv}$.

Rudels (2011) extended the earlier conceptual geostrophic model (Rudels, 1986b) by adding a sea level slope, based on the differences in steric height between the Arctic Ocean and Labrador Sea above $800 \mathrm{~m}$ to the sea level difference between the Arctic Ocean and Baffin Bay. This allowed for a possibility to also exchange the intermediate water in Baffin Bay. The salinity of the upper layer outflow from the Arctic Ocean for which also the flows through Nares Strait and in the West Greenland Current, supplying the intermediate layer in Baffin Bay, were balanced by an intermediate outflow through Davis Strait, was then determined. The obtained upper layer salinity was $\sim 33.1$, leading to transports in the upper layer of about $0.8 \mathrm{~Sv}$ in both Lancaster Sound and Nares Strait and a deep transport through Nares Strait of $0.6 \mathrm{~Sv}$ to Baffin Bay. The outflow from the Arctic Ocean through Davis Strait then becomes $\sim 2.2 \mathrm{~Sv}$. These estimates lie in the upper end of the spectrum.

\subsection{Freshwater budget}

The import, export and storage of freshwater in the Arctic Ocean have recently become the foci of much research. The early budgets for the Arctic Ocean concentrated on volume, heat and occasionally salt fluxes (e.g. Aagaard and Greisman, 1975). However, salinity transports have presently largely been replaced by freshwater transports, usually computed relative to a reference salinity of 34.80, and in their pioneering work Aagaard and Carmack (1989) formed a freshwater budget for the Arctic Ocean as well as for the Nordic Seas (Fig. 34).

The reasons for the growing interest in the freshwater export from the Arctic Ocean were model investigations based on Stommel's (1961) concept of two possible modes of the thermohaline circulation. It has one positive, thermal, mode with cold water sinking at high latitudes and upwelling to the surface at low latitudes and a second, negative, salinity (freshwater) driven mode, where the heating and evaporation at low latitudes create higher densities than the cooling and precipitation at high latitudes and the circulation is reversed. Water is sinking in low latitudes and brought to the surface at high latitudes. The freshwater driven mode is less efficient in transporting volume and heat to high latitudes since the warm water becomes covered by a colder, less saline upper layer that further diminishes the heat loss. A possible switch from the presently thermally driven thermohaline circulation to a freshwater driven circulation could then have impact on the present climate. Moreover, the change from one mode to the other could be sudden, when a critical, unknown, freshwater input is reached and the return to the thermal mode would not occur before the freshwater input has decreased well below the critical value (Stommel, 1961). This concept has been elaborated by Rooth (1982) and by Rahmstorf (1995) and led to intensified studies, both theoretical and observational, of the stability of the thermohaline circulation. Much of the work in the VEINS and ASOF projects was dedicated to determine the coupling between the freshwater transports and the thermohaline circulation (Dickson et al., 2008).

After the budget formulated by Aagaard and Carmack (1989) several new attempts have been made to quantify the freshwater fluxes (Serreze et al., 2006; Dickson et al., 2007). Dickson et al. (2007) made one "conventional" budget relative to salinity 34.80 and a second one using the salinity 35.2 , representing the inflow salinity of the Atlantic water to the Arctic Mediterranean Sea, the highest salinity available. This second approach has the advantage that the freshwater transports and the volume transports always are in the same direction. It showed that freshwater is exported from the Arctic Mediterranean not only in the upper layers but also that the overflow waters carry freshwater from the Arctic Mediterranean into the deeper layers of the North Atlantic (Fig. 35).

In the wake of the ongoing reduction in sea ice volume the storage of freshwater inside the Arctic Ocean has received increased attention. The accumulation of freshwater has been concentrated to the Canada Basin and especially to the Beaufort Gyre (Proshutinsky et al., 2009; Rabe et al., 2011). The accumulation is largely caused by the negative AO situation that has dominated in recent years, which by Ekman convergence forces the water into the gyre. With the use of -18 measurements it has been possible to determine the contributions from river water and sea ice melt water. YamamotoKawai et al. (2009) estimated the increase in melt water content between 2005 and 2007 to $2.5 \mathrm{~m}$. The melt water fraction at $50 \mathrm{~m}$ depth had not changed significantly suggesting that the increase in melt water is due to summer melt, not to less ice formation in winter. Closer to the North American continent the ice melt increase in the upper layer is less. However, here the changes are at $50 \mathrm{~m}$ depth indicating a weaker ice formation in winter and thus an increase in melt water content (Yamamoto-Kawai et al., 2009).

By measuring Barium (Guay et al., 2009) or Alkalinity (Yamamoto-Kawai et al., 2009) it is possible to determine the origin of the river runoff in the Canada Basin and on the Chukchi shelf. The Barium concentrations and the Alkalinity are twice as high in the North American rivers than in the Siberian rivers entering the Arctic Ocean. It is found that only close to the McKenzie river is the Alkalinity and Barium concentrations in the upper $20 \mathrm{~m}$ high enough to indicate runoff from North America. The McKenzie outflow would then almost directly enter the Canadian Arctic Archipelago. Farther to the west the main sources of runoff are the Siberian rivers. The freshwater is probably advected with the East Siberian Coastal Current to the Chukchi shelf and then continuing along the Alaskan shelf (Guay et al., 2009; Yamamoto-Kawai et al., 2009).

This is not the only path for waters from the Siberian rivers to enter the Canada Basin. In a highly positive AO situation the circulation in the Eurasian Basin will become cyclonic, forcing the shelf water from the Siberian branch of the Transpolar Drift to move into the Makarov Basin and there be trapped by the diminished Beaufort Gyre (Morison et al., 2012). This pathway has been delineated from satellite gravimetry and satellite altimetry separating the effects of sea level slope and steric heights and shows that also river runoff from Siberia contributes to the freshwater accumulation in the Beaufort Gyre (Morison et al., 2012). However, the shelf waters farther to the west, in the Laptev and Kara seas, are too saline and dense to enter the surface layer and they will penetrate into the halocline of the Canada Basin.

The freshwater exports from the Arctic Ocean east and west of Greenland are about equal, but while $2 / 3$ of the freshwater trans- 

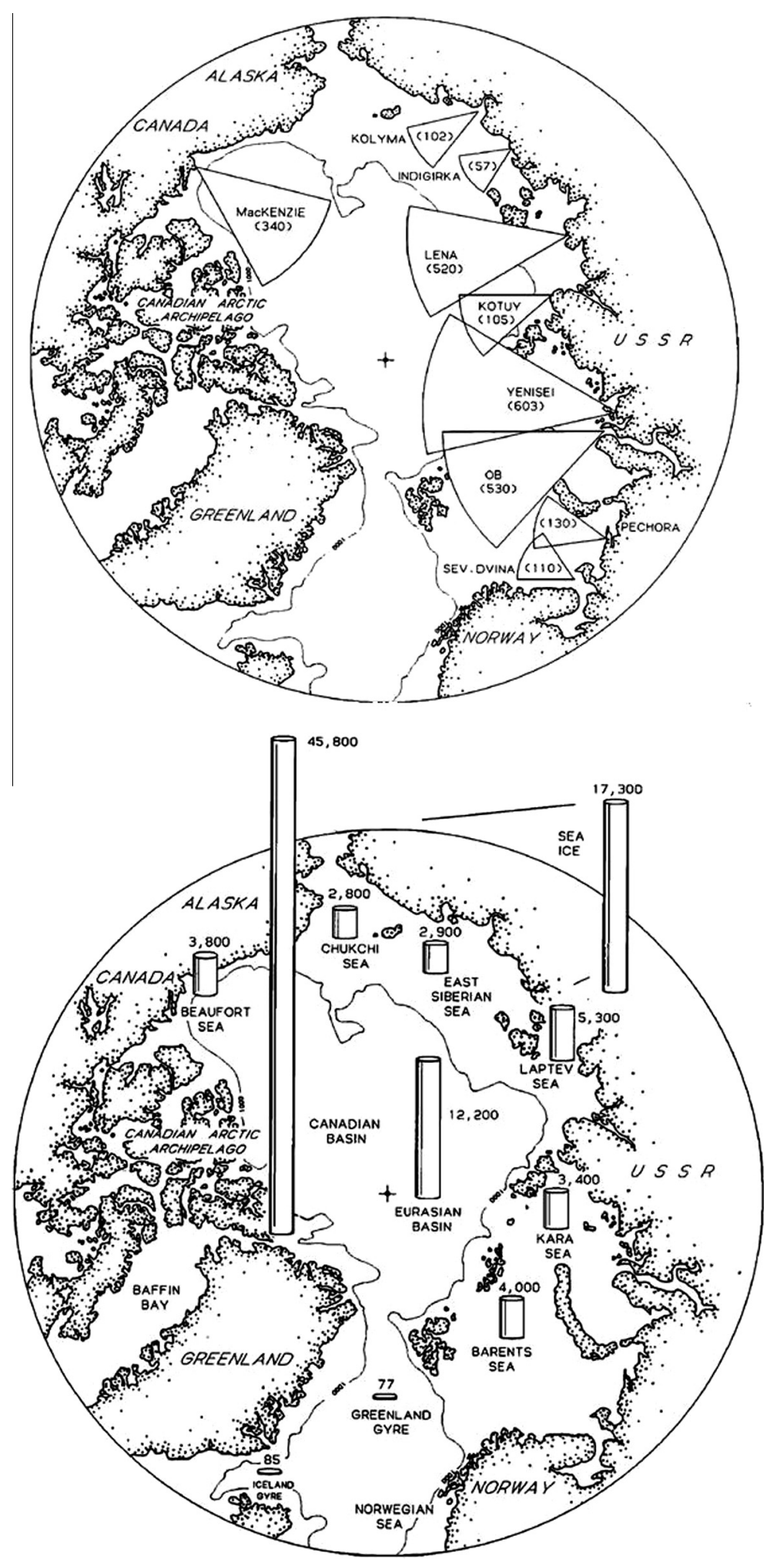

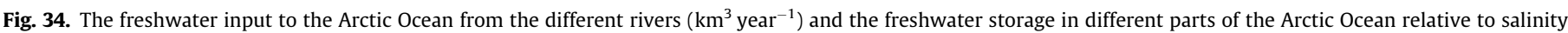
$34.80\left(\mathrm{~km}^{3}\right)$ (from Aagaard and Carmack, 1989).

port through Fram Strait occurs as ice the liquid freshwater export dominates almost completely in the Canadian Arctic Archipelago. This suggests that in the case of a diminishing, or vanishing, ice export the Canadian Arctic Archipelago would have the largest freshwater export, which might affect the dense water formation in the deep convection areas in the Labrador Sea and in the Irminger Sea and thus the thermohaline circulation.
The positive freshwater balance is only one aspect of the Arctic Mediterranean Sea as a high latitude ocean. What also characterises the high latitude oceans is that the stability in the upper part is determined by salinity, not temperature. Only below the Atlantic layer does the temperature become stabilising in the Arctic Ocean and in the deep water salinity again determines the stability. This fact was used by Carmack (2000) to classify the high latitude 

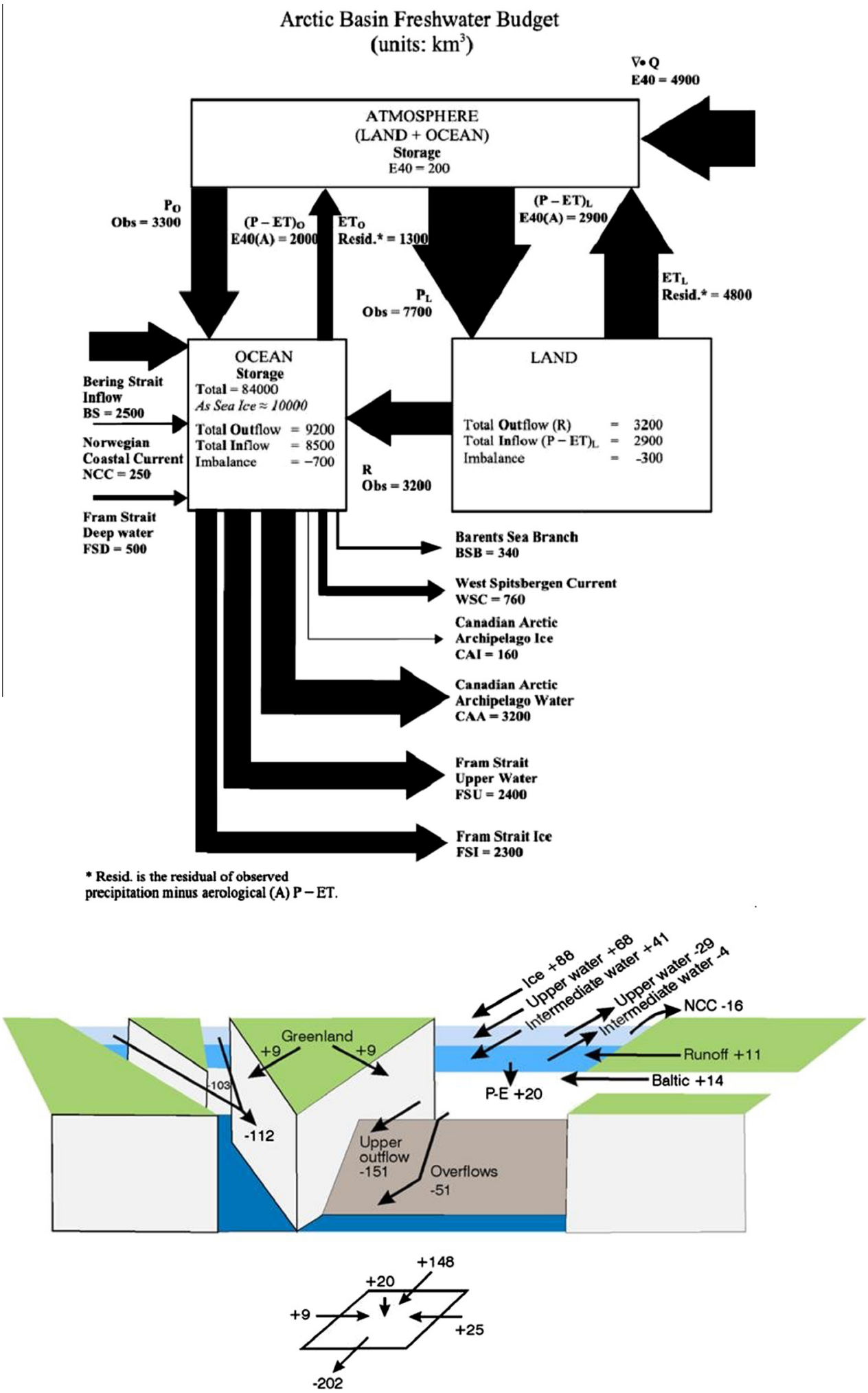

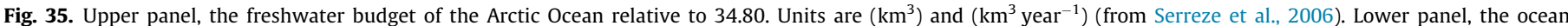

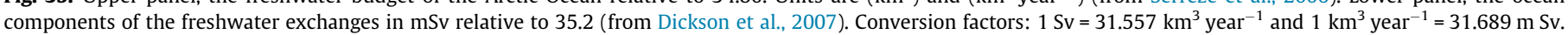

oceans as $\beta$-oceans in contrast to the temperature dominated $\alpha$-oceans at lower latitudes. $\alpha$ and $\beta$ here stand for the coefficients of heat expansion and salt contraction respectively. This implies that to create water dense enough to ventilate the deeper layers the salinity has to increase. This occurs during freezing and brine rejection on the shelves but also, albeit more localised, in the deep ocean. Rudels (1993) examined these cold, saline high latitude deep water sources and their possible importance for creating the dense water ventilating the deep world ocean.

The importance of the Arctic Mediterranean Sea as a receiver and redistributer of freshwater between the atmosphere and ocean and between the different oceans, the North Pacific and the North 


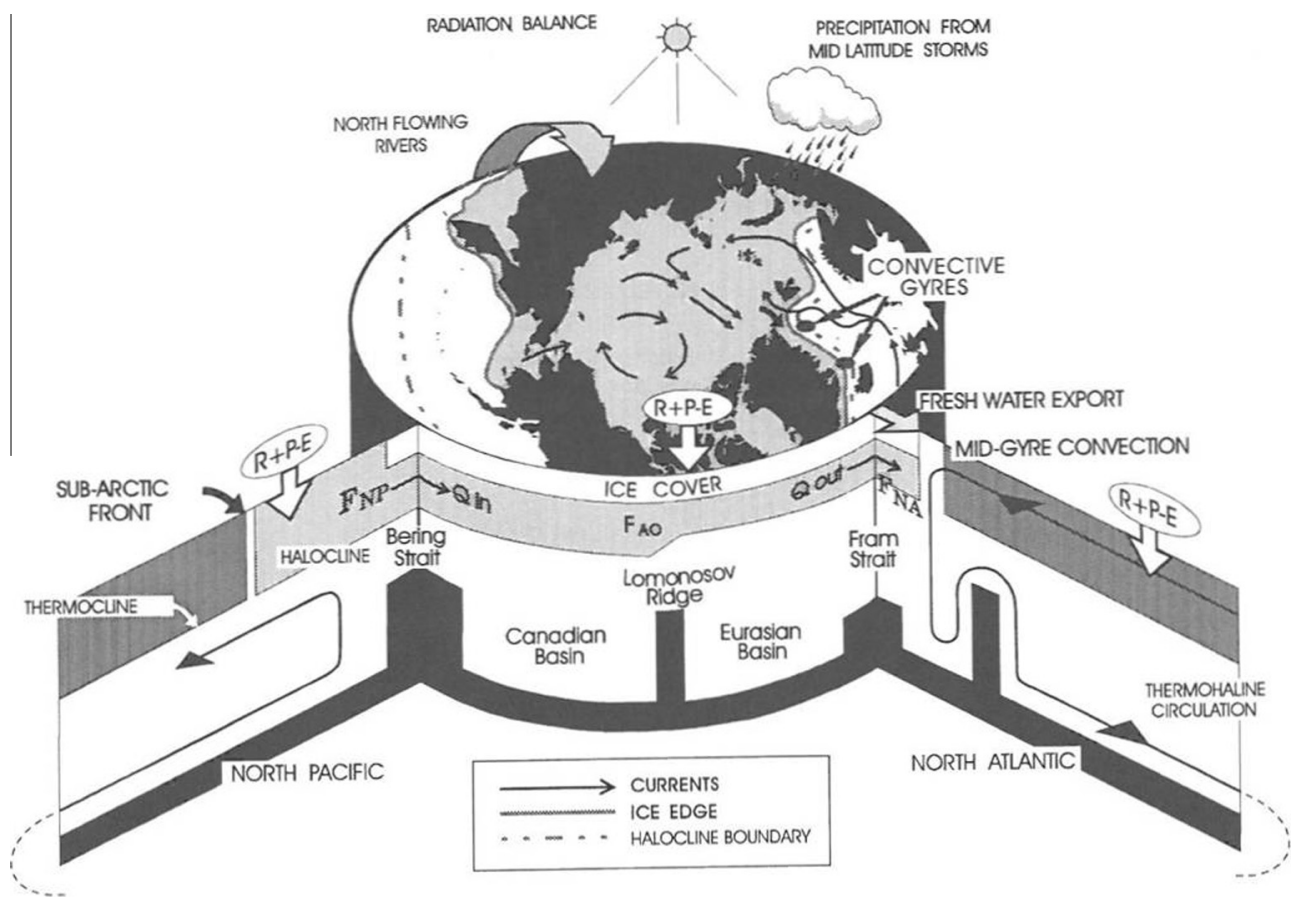

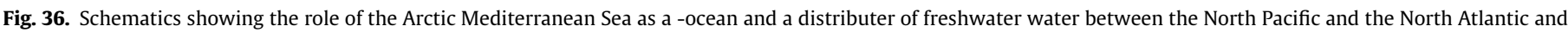
between high and low latitudes as well as its contributions to the deep overturning circulation (from Aagaard and Carmack, 1994).

Atlantic, and as well as the ventilation of the deep ocean at high latitudes was summarised by Aagaard and Carmack (1994) in the schematics shown in Fig. 36. This global view has been elaborated by Carmack in subsequent studies (Carmack, 2000; Carmack and Wassmann, 2006).

\section{Summary}

This overview of how the knowledge and understanding of the circulation, water mass transformations and mixing processes in the Arctic Ocean has evolved through time intentionally focus on the era before the fourth International Polar Year 2007-2009. The scope is not exhaustive and has rather been biased by the author's main interest in the description and interpretation of hydrographic observations. The observations made during, and after, IPY have already added much new knowledge about the Arctic Ocean, its state, its processes, and its possible change. However, even when the amount of available information, measurements and data increases, it might still be valuable to know about previous investigations and how insights have been gained and developed to create an ever more complete picture of the Arctic Ocean and its role in the Arctic climate and in the global ocean.

\section{Acknowledgements}

I want to thank Meri Korhonen and two referees for their comments and advice. The research leading to these results has received funding from the European Union 6th Framework Programme under Grant Agreement No. 018509 DAMOCLES and the 7th Framework Programme (FP7 2007-2013) under Grant Agreements No.: 212643 THOR and No.: 308299 NACLIM.

\section{References}

Aagaard, K., 1980. On the deep circulation in the Arctic Ocean. Deep-Sea Research 27, 251-268.
Aagaard, K., 1989. A synthesis of the Arctic Ocean circulation. Rapports et ProcèsVerbaux des Réunions du Conseil International pour l'Exploration de la Mer $188,11-22$

Aagaard, K., Carmack, E.C., 1989. The role of sea ice and other freshwater in the Arctic circulation. Journal of Geophysical Research 94, 14485-14498.

Aagaard, K. Carmack, E.C. 1994. The Arctic Ocean and climate: a perspective. In: Johannessen, O.M., Muench, R.D., Overland, J.E. (Eds.), The Polar Oceans and Their Role in Shaping the Global Climate. American Geophysical Union, Washington, pp. 5-20.

Aagaard, K., Coachman, L.K., 1975. Toward an ice-free Arctic Ocean. Eos 56, 484 486.

Aagaard, K., Greisman, P., 1975. Towards a new mass and heat budget for the Arctic Ocean. Journal of Geophysical Research 80, 3821-3827.

Aagaard, K., Woodgate, R.A., 2001. Some thoughts on the freezing and melting of sea ice and their effects on the ocean. Ocean Modelling 3, 127-135.

Aagaard, K., Darnall, C., Greisman, P., 1973. Year-long measurements in the Greenland-Spitsbergen passage. Deep-Sea Research 20, 743-746.

Aagaard, K., Coachman, L.K., Carmack, E.C., 1981. On the halocline of the Arctic Ocean. Deep-Sea Research 28, 529-545.

Aagaard, K., Swift, J.H., Carmack, E.C., 1985. Thermohaline circulation in the Arctic Mediterranean Seas. Journal of Geophysical Research 90, 4833-4846.

Aagaard, K., Barrie, L.A., Carmack, E.C., Garrity, C., Jones, E.P., Lubin, D., Macdonald, R.W., Swift, J.H., Tucker, W.B., Wheeler, P.A., Whritner, R.H., 1996. U.S., Canadian researchers explore the Arctic Ocean. Eos 177, 209.

Aagaard, K., Andersen, R., Swift, J., Johnson, J., 2008. A large eddy in the centra Arctic Ocean. Geophysical Research Letters 35, L09601. http://dx.doi.org 10.1029/2008GL033461.

Aksenov, Y., Bacon, S., Coward, A.C., Nurser, A:J:G:, 2010a. The North Atlantic inflow to the Arctic Ocean: high-resolution model study. Journal of Marine Systems 79 1-22. http://dx.doi.org/10.1016/j.jmarsys.2009.05.003.

Aksenov, Y., Bacon, S., Coward, A.C., Holliday, N.P., 2010b. Polar outflow from the Arctic Ocean: a high resolution model study. Journal of Marine Systems 83, 1437. http://dx.doi.org/10.1016/j.jmarsys.2010.06.007.

Aksenov, Y., Ivanov, V.V., Nurser, A.J.G., Bacon, S., Polyakov, I.V., Coward, A.C. Naveira-Garabato, A.C., Beszczynska-Möller, A., 2011. The Arctic circumpolar boundary current. Geophysical Research 116, C09017. http://dx.doi.org/ 10.1029/2010JC006637.

Anderson, L.G., Jones, E.P., Lindegren, R., Rudels, B., Sehlstedt, P.-I., 1988. Nutrient regeneration in cold, high salinity bottom water of the Arctic shelves. Continental Shelf Research 8, 1345-1355.

Anderson, L.G., Jones, E.P., Koltermann, K.P., Schlosser, P., Swift, J.H., Wallace, D.W.R. 1989. The first oceanographic section across the Nansen Basin in the Arctic Ocean. Deep-Sea Research 36, 475-482.

Anderson, L.G., Björk, G., Holby, O., Jones, E.P., Kattner, G., Koltermann, K.-P. Liljeblad, B., Lindegren, R., Rudels, B., Swift, J.H., 1994. Water masses and circulation in the Eurasian Basin: results from the Oden 91 Expedition. Journal of Geophysical Research 99, 3273-3283. 
Anderson, L.G., Jutterström, S., Kaltin, S., Jones, E.P., Björk, G., 2004. Variability in river runoff distribution in the Eurasian Basin of the Arctic Ocean. Journal of Geophysical Research 109, C01016. http://dx.doi.org/10.1029/2003JC00173.

Bailey, W.B., 1956. On the origin of Baffin Bay Deep Water. Journal of Fisheries Research Board Canada 13 (3), 303-308.

Bailey, W.D., 1957. Oceanographic features of the Canadian Archipelago. Journal of Fisheries Research Board Canada 14, 731-769.

Belyakov, L.N., Volkov, V.A., 1980. Doklady Akademii Nauk SSR 254 (3), 752-754 (in Russian).

Beszczynska-Möller, A., Beszczynska-Möller, A., Woodgate, R.A., Lee, C., Melling, H. Karcher, M., 2011. A synthesis of exchanges through the main oceanic gateways to the Arctic Ocean. Oceanography 24, 82-99.

Beszczynska-Möller, A., Fahrbach, E., Schauer, U., Hansen, E., 2012. Variability in Atlantic water temperature and transport at the entrance of the Arctic Ocean 1997-2010. ICES Journal of Marine Science 69, 852-863. http://dx.doi.org $10.1093 /$ icesjms/fss056.

Björk, G., Winsor, P., 2006. The deep waters of the Eurasian Basin, Arctic Ocean: geothermal heat flow, mixing and renewal. Deep-Sea Research I 53, 1253-1271. http://dx.doi.org/10.1016/jdsr.2006.05.006.

Björk, G., Söderqvist, J., Winsor, P., Nikolopoulos, A., Steele, M., 2002. Return of the cold halocline to the Amundsen Basin of the Arctic Ocean: implication for the sea ice mass balance. Geophysical Research Letters 29 (11), 1513. http:// dx.doi.org/10.1029/2001GL014157.

Björk, G., Jakobsson, M., Rudels, B., Swift, J.H., Anderson, L.G., Darby, D.A., Backman, J., Coakley, B., Winsor, P., Polyak, L., Edwards, M., 2007. Bathymetry and deepwater exchange across the central Lomonosov Ridge at $88^{\circ}-89^{\circ} \mathrm{N}$. Deep-Sea Research I 54, 1197-1208. http://dx.doi.org/10.1016/j.dsr.2007.05.010.

Björk, G., Anderson, L.G., Jakobsson, M., Antony, D., Eriksson, B., Eriksson, P., Hell, B. Hjalmarsson, S., Janzen, T., Jutterström, S., Linders, J., Löwemark, L., Marcussen, C., Olsson, K.A., Rudels, B., Sellén, E., Sølvsten, M., 2010. Flow of Canadian Basin deep water in the Western Eurasian Basin of the Arctic Ocean. Deep-Sea Research I 57, 577-586. http://dx.doi.org/10.1016/j.dsr.2010.01.006.

Blindheim, J., 1989. Cascading of Barents Sea bottom water into the Norwegian Sea. Rapports et Procès-Verbaux des Réunions du Conseil International pour l'Exploration de la Mer 188, 49-58.

Bourke, R.H., Paquette, R.G., 1991. Formation of Baffin Bay bottom and deep waters In: Chu, P.C., Gascard, J.C. (Eds.), Deep Convection and Deep Water Formation in the Oceans. Elsevier, Amsterdam, pp. 135-155.

Bourke, R.H., Weigel, A.M., Paquette, R.G., 1988. The westward turning branch of the West Spitsbergen Current. Journal of Geophysical Research 93, 14065-14077.

Bourke, R.H., Addison, V.G., Paquette, R.G., 1989. Oceanography of Nares Strait and Northern Baffin Bay in 1986 with emphasis on Deep and Bottom Water Formation. Journal of Geophysical Research 94, 8289-8302.

Boyd, T.J., Steele, M., Muench, R.D., Gunn, J.T., 2002. Partial recovery of the Arctic Ocean halocline. Geophysical Research Letters 29 (14), 1657. http://dx.doi.org 10.1029/2001GL014047.

Budéus, G., Ronski, S., 2009. An integral view of the hydrographic development in the Greenland Sea over a decade. The Open Oceanography Journal 3, 8-39.

Carmack, E.C., 1986. Circulation and mixing in ice covered waters. In: Untersteiner N. (Ed.), The Geophysics of Sea Ice. Plenum Press, New York, pp. 641-712.

Carmack, E.C. 2000. The Arctic Ocean's freshwater budget: sources, storage and export. In: Lewis, E.L., Jones, E.P., Lemke, P., Prowse, T.D. (Eds.), The Freshwate Budget of the Arctic Ocean, NATO Science Series, 2 Environmental Security, vol 70. Kluwer Academic Publishers, Dordrecht, pp. 91-126.

Carmack, E.C., Wassmann, P., 2006. Food webs and physical-biological coupling on pan-Arctic shelves. Unifying concepts and comprehensive perspectives. Progress in Oceanography 71 (2-4), 446-477.

Carmack, E.C., Macdonald, R.W., Perkin, R.G., McLaughlin, F.A., 1995. Evidence for warming of Atlantic water in the southern Canadian Basin. Geophysical Research Letters 22, 1961-1964.

Carmack, E.C., Aagaard, K., Swift, J.H., Macdonald, R.W., McLaughlin, F. A., Jones, E.P., Perkin, R.G., Smith, J.N., Ellis, K.M., Killius, L.R., 1997. Changes in temperature and tracer distributions within the Arctic Ocean: results from the 1994 Arctic Ocean section. Deep-Sea Research II 44, 1487-1502.

Carpenter, J.R., Timmermans, M.-L., 2012. Deep mesoscale eddies in the Canada Basin, Arctic Ocean. Geophysical Research Letters 39, L20602. http://dx.doi.org/ 10.1029/2012GL053025.

Chapman, D.C., Gawarkiewicz, G., 1997. Shallow convection and buoyancy equilibrium in an idealized coastal polynya. Journal of Physical Oceanography $27,555-566$

Coachman, L.K., Aagaard, K., 1966. On the water exchange through Bering Strait. Limnology and Oceanography 11, 44-59.

Coachman, L.K., Aagaard, K., 1974. Physical oceanography of the arctic and subarctic seas. In: Herman, Y. (Ed.), Marine Geology and Oceanography of the Arctic Seas. Springer Verlag, New York, pp. 1-72.

Coachman, L.K., Aagaard, K., 1988. Transports through Bering Strait: annual and interannual variability. Journal of Geophysical Research 93, 15535-15539.

Coachman, L.K., Barnes, C.A., 1961. The contribution of Bering Sea water to the Arctic Ocean. Arctic 14, 147-161.

Coachman, L.K., Barnes, C.A., 1962. Surface waters in the Eurasian Basin of the Arctic Ocean. Arctic 15, 251-277.

Coachman, L.K., Barnes, C.A., 1963. The movement of Atlantic water in the Arctic Ocean. Arctic 16, 8-16.

Coachman, L.K., Aagaard, K., Tripp, R., 1975. Bering Strait: The Regional Physical Oceanography. Univ, of Washington Press, Seattle, 172 pp.
Collin, A.E., Dunbar, M.J., 1963. Physical oceanography in Arctic Canada. Oceanography and Biology, Annual Review 2, 45-77.

Cuny, J., Rhines, P.B., Kwok, R., 2006. Davis Strait volume, freshwater and heat fluxes. Deep-Sea Research I 52, 519-542.

Curry, B., Lee, C.M., Petrie, B., 2011. Volume, freshwater, and heart fluxes through Davis Strait, 2004-2005. Journal of Physical Oceanography 41, 429-436. http:// dx.doi.org/10.1175/2010JPO4536.1.

D'Asaro, E.A., 1988a. Observations of small eddies in the Beaufort Sea. Journal of Geophysical Research 93, 6669-6684.

D’Asaro, E.A., 1988b. Generation of submesoscale vortices: a new mechanism. Journal of Geophysical Research 93, 6685-6693.

Day, C.G., 1968. Current measurements in Smith Sound, summer 1963. USCG Oceanography Report 16, 75-84

Dewey, R., Muench, R., Gunn, J., 1999. Mixing and vertical heat flux estimates in the Arctic Eurasian Basin. Journal of Marine Systems 21, 199-205.

Dickson, R.R., 2008. The Integrated Arctic Ocean Observing System (iAOOS) in 2007. A Report of the Arctic Ocean Sciences Board, $42 \mathrm{pp}$.

Dickson, R.R., 2009. The Integrated Arctic Ocean Observing System (iAOOS) in 2008. A Report of the Arctic Ocean Sciences Board, 82 pp.

Dickson, R.R., 2011. iAOOS: An Ocean-Observing System for the Northern Sea During the Legacy Phase of the International Polar Year, $58 \mathrm{pp}$

Dickson, R.R., Fahrbach, E., 2010. Observing Our Northern Seas During the IPY. A Report of the Arctic Ocean Sciences Board and of the IPY Joint Committee, $34 \mathrm{pp}$.

Dickson, R.R., Rudels, B., Dye, S., Karcher, M., Meincke, J., Yashayaev, I., 2007. Current estimates of freshwater flux through the Arctic and Subarctic seas. Progress in Oceanography 73, 210-230. http://dx.doi.org/10.1016/j.pocean.2006.12003.

Dickson, R.R., Meincke, J., Rhines, P. (Eds.), 2008. Arctic, Sub-arctic Ocean Fluxes: Defining the Role of the Northern Seas in Climate. Springer, p. 736

Dmitrenko, I., Timokhov, L., Andreev, O., Chadwell, R., Churkin, O., Dempsey, M. Kirillov, S., Smoliansky, V., Mastrukov, S., Nitishinskiy, M., Polyakov, I., Repina, I., Ringuette, M., Vetrov, A., Walsh, D., 2005. NABOS D-04 Expedition on the Northern Laptev Sea aboard the Icebreaker Kapitan Dranitsyn (September 2004). IARC Technical Report 2, 113 pp.

Dmitrenko, I.A., Polyakov, I.V., Kirillov, S.A., Timokhov, L.A., Simmons, H.L., Ivanov, I.V., Walsh, D., 2006. Seasonal variability of Atlantic water on the continental slope of the Laptev Sea during 2002-2004. Earth and Planetary Science Letters 244 (3-4), 735-743. http://dx.doi.org/10.1016/j.epsl.2006.01.067.

Dmitrenko, I.A., Polyakov, I.V., Kirillov, S.A., Timokhov, L.A., Frolov, I.E., Sokolov, V.T., Simmons, H.L., Ivanov, V.V., Walsh, D., 2008a. Towards a warmer Arctic Ocean: spreading of the early 21 st century Atlantic Water warm anomaly along the Eurasian Basin margins. Journal of Geophysical Research 113, C05023. http:// dx.doi.org/10.1029/2007JC004158.

Dmitrenko, I.A., Kirillov, S.A., Ivanov, V.I., Woodgate, R., 2008b. Mesoscale Atlantic water eddy off the Laptev Sea continental slope carries the signature of upstream interaction. Journal of Geophysical Research 106 (113), C07005. http://dx.doi.org/10.1029/2007JC004491.

Dmitrenko, I.A., Bauch, D., Kirillov, S.A., Koldunov, N., Minnett, P.J., Ivanov, V.I., Hölemann, J.A., Timokhov, L.A., 2009. Barents Sea upstream events impact the properties of Atlantic water inflow into the Arctic Ocean: evidence from 2005 to 2006 downstream observations. Deep-Sea Research I 56, 513-517. http:// dx.doi.org/10.1016/j.dsr.2008.11.005.

Dye, S.R., Nolan, G.D., Beszczynska-Möller, A., 2012. ICES Report on Ocean Climate 2011, ICES Cooperative Research Report No. 314, 77 pp.

Ekman, V.W., 1905. On the influence of earth's rotation on ocean currents. Arkiv för matematik, astronomi och fysik 2 (11), 53.

Fahrbach, E., 2006. ASOF-N Final Report (2006) Bremerhaven, 112 pp.

Fahrbach, E., Meincke, J., Østerhus, S., Rohardt, G., Schauer, U., Tverberg, V., Verduin, J., 2001. Direct measurements of volume transports through Fram Strait. Polar Research 20, 217-224.

Falkner, K.K., Steele, M., Woodgate, R.A., Swift, J.H., Aagaard, K., Morison, J., 2005. Dissolved oxygen extrema in the Arctic Ocean halocline from the North Pole to the Lincoln Sea. Deep-Sea Research I 52, 1138-1154.

Fedorova, A.P., Yankina, A.S., 1964. The passage of Pacific Ocean water through the Bering Strait into the Chukchi Sea. Deep-Sea Research 11, 427-434.

Fieg, K., Gerdes, R., Fahrbach, E., Beszczynska-Möller, A., Schauer, U., 2010. Simulation of oceanic volume transports through Fram Strait 1995-2005. Ocean Dynamics 60, 491-502. http://dx.doi.org/10.1007/s10236-010-0263-9.

Fjeldstad, J.E., 1936. Results of tidal observations. Norwegian North Polar Expedition "Maud"1918-1925. Science Research 4 (4), 88

Fletcher, J.O. 1965. The heat budget of the Arctic Basin and its relation to climate. The Rand Corporation R. 444-PR, Santa Monica, California, 179 pp.

Foldvik, A., Aagaard, K., Törresen, T., 1988. On the velocity field of the East Greenland Current. Deep-Sea Research 35, 1335-1354.

Frank, M., Smethie, W.M., Bayer, R., 1998. Investigation of subsurface water flow along the continental margin of the Eurasian Basin using transient tracers tritium, ${ }^{3} \mathrm{He}$, and CFCs. Journal of Geophysical Research 103, 3077330792.

Gammelsrød, T., Leikvin, Ø., Lien, V., Budgell, W.P., Loeng, H., Maslowski, W., 2009. Mass and heat transports in the NE Barents Sea: observations and models. Journal of Marine Systems 75, 56-69.

Gawarkiewicz, G., 2000. Effects of ambient stratification and shelf-break topography buoyancy equilibrium in an idealised coastal polynya. Journal of Geophysical Research 105, 3307-3324.

Gawarkiewicz, G., Weingartner, T., Chapman, D.C., 1998. Sea-ice processes and water mass modification and transports over Arctic shelves. In: Brink, K.H., Robinson, A.R. (Eds.), The Sea, vol. 10. Wiley, New York, pp. 171-190. 
Gorshkov, S.G., 1980. World Ocean Atlas 3, The Arctic Ocean, USSR Ministry of Defence, Leningrad, XIV, $180 \mathrm{pp}$.

Grotefendt, K., Logemann, K., Quadfasel, D., Ronski, S., 1998. Is the Arctic Ocean warming? Journal of Geophysical Research 103, 27679-27687.

Guay, C.K.H., McLaughlin, F.A., Yamamoto-Kawai, M., 2009. Differentiating fluvial components of upper Canada Basin waters on the basis of measurements of dissolved barium combined with other physical and chemical tracers. Journal of Geophysical Research 114, C00A09. http://dx.doi.org/10.1029/2008JC005099.

Hamilton, J.M., 2001. Accurate ocean current direction measurements near magnetic poles. In:The 11th International Offshore and Polar Engineering Conference Proc. ISOPE, Stavanger, vol. I, pp. 815-846.

Harris, R.A., 1911. Arctic Tides. U.S. Printing Office, Washington, DC, 103 pp.

Hart, J.E., Killworth, P.D., 1976. On open-ocean baroclinic instability in the Arctic. Deep-Sea Research 23 (7), 637-645.

Helland-Hansen, B., Nansen, F. 1909. The Norwegian Sea. Its Physical Oceanography Based upon the Norwegian Researches 1900-1904. Rep. on Norw. Fishery and Marine Investigations II(1), Kristiania, 390 pp.

Holfort, J., Hansen, E., Østerhus, S., Dye, S., Jónsson, S., Meincke, J., Mortensen, J., Meredith, M., 2008. Freshwater fluxes east of Greenland. In: Dickson, R.R. Meincke, J., Rhines, P. (Eds.), Arctic-Subarctic Ocean Fluxes. Springer, Dordrecht, pp. 263-287.

Holliday, N.P., Hughes, S.L., Bacon, S., Beszczynska-Möller, A., Hansen, B., Lavin, A. Loeng, H., Mork, K.A., Østerhus, S., Sherwin, T., Walczowski, W., 2008. Reversal of the 1960s to 1990s freshening trend in the Northeast North Atlantic and the Nordic Seas. Geophysical Research Letters 35, L03614. http://dx.doi.org/ 10.1029/2007GL032675.

Houssais, M.-N., Herbaut, C., 2011. Atmospheric forcing on the Canadian Arctic Archipelago freshwater outflow and implications for the Labrador Sea variability. Journal of Geophysical Research 116, C00D02. http://dx.doi.org/ 10.1029/2010JC006323.

Hunkins, K., 1974. Subsurface eddies in the Arctic Ocean. Deep-Sea Research 21, $1017-1033$.

Hunkins, K., 1981. Arctic Ocean Eddies and Baroclinic Instability. CU-2-81 Technical Report No. 2. Office of Naval Research contract N00014-76-c-004, LamontDoherty Geological, Observatory, $40 \mathrm{pp}$.

Hurrell, J.W., 1995. Decadal trends in the North Atlantic Oscillation: regional temperatures and precipitation. Science 269, 677-679.

Ingvaldsen, R.B., Asplin, L., Loeng, H., 2004a. Velocity field of the western entrance to the Barents Sea. Journal of Geophysical Research 109, C03021. http:// dx.doi.org/10.1029/2003JC001811.

Ingvaldsen, R.B., Asplin, L., Loeng, H., 2004b. The seasonal cycle in the Atlantic transport to the Barents Sea during the years 1997-2001. Continental Shelf Research 24, 1015-1032.

Ivanov, V.I., Polyakov, I.V., Dmitrenko, I.A., Hansen, E., Repina, I.A., Kirillov, S.A., Mauritzen, C., Simmons, H., Timokhov, L.A., 2009. Seasonal variability in the Atlantic water off Spitsbergen. Deep-Sea Reseach I 56, 1-14. http://dx.doi.org/ 10.1016/j.dsr.2008.07.013.

Jakobsson, M., Cherkis, N., Woodward, J., Coakley, B., Macnab, R., 2000. A new grid of Arctic bathymetry: a significant resource for scientists and mapmakers. EOS Transactions, AGU 81 (9), 89-93, 96.

Jakobsson, M., Grantz, A., Kristoffersen, Y., Macnab, R., 2004. Bathymetry and physiography of the Arctic Ocean and its constituent seas. In: Stein, R., Macdonald, R.W. (Eds.), The Organic Carbon Cycle in the Arctic Ocean. Springer, Heidelberg, pp. 1-6.

Jakobsson, M., Macnab, R., Mayer, L., Anderson, R., Edwards, M., Hatzky, J., Schenke, H.W., Johnson, P., 2008. An improved bathymetric portrayal of the Arctic Ocean: implications for ocean modelling and geological, geophysical and oceanographic analyses. Geophysical Research Letters 35, L07602. http:/ dx.doi.org/10.1029/2008GL033520.

Jones, E.L., Andersn, L.G., 2008. Is the global conveyor belt threatened by Arctic Ocean freshwater outflow? In: Dickson, R.R., Meincke, J., Rhines, P. (Eds.), Arctic-Subarctic Ocean Fluxes. Springer, Dordrecht, pp. 385-404.

Jones, E.P., Anderson, L.G., 1986. On the origin of the chemical properties of the Arctic Ocean halocline. Journal of Geophysical Research 91, 10759-10767.

Jones, E.P., Rudels, B., Anderson, L.G., 1995. Deep waters of the Arctic Ocean: origins and circulation. Deep-Sea Research 42, 737-760.

Jones, E.P., Anderson, L.G., Swift, J.H., 1998. Distribution of Atlantic and Pacific waters in the upper Arctic Ocean: implications for circulation. Geophysical Research Letters 25, 765-768.

Jones, E.P., Swift, J.H., Anderson, L.G., Lipizer, M., Civitarese, G., Falkner, K.K., Kattner, G., McLaughlin, F.A., 2003. Tracing Pacific water in the North Atlantic Ocean. Journal of Geophysical Research 108 (C4), 3116. http://dx.doi.org/10.1029/ 2001JC001141.

Karcher, M.J., Gerdes, R., Kauker, F., Köberle, C., 2003. Arctic warming - evolution and spreading of the 1990s warm event in the Nordic seas and in the Arctic Ocean. Journal of Geophysical Research 108, 3034. http://dx.doi.org/10.1029/ 201JC001265.

Karcher, M., Beszczynska-Möller, A., Kauker, F., Gerdes, R., Heyen, S., Rudels, B., Schauer, U., 2011. Arctic Warming and its consequences for the Denmark Strait overflow. Journal of Geophysical Research 116, C02037. http://dx.doi.org/ 10.1029/2010JC006265.

Kelley, D.E., 1990. Fluxes through diffusive interfaces: a new formulation. Journal of Geophysical Research 95, 3365-3371.
Kiilerich, A., 1939. The Godthaap Expedition 1928. A theoretical treatment of the hydrographical observation material. Meddelelser om Grønland 78 (5), 149.

Kikuchi, T., Hatakeyama, K., Morison, J.H., 2004. Distribution of convective lower halocline water in the eastern Arctic Ocean. Journal of Geophysical Research 109, C120301. http://dx.doi.org/10.1029/2003JC002223.

Kikuchi, T., Inoue, J., Morison, J.H., 2005. Temperature differences across the Lomonosov Ridge: implication for the Atlantic Water circulation in the Arctic Ocean. Geophysical Research Letters 32, L20604. http://dx.doi.org/10.1029/ 2005GL023982.

Kliem, N., Greenberg, D.A., 2003. Diagnostic simulations of the summer circulation in the Canadian Arctic Archipelago. Atmosphere-Ocean 41, 273-289. http:// dx.doi.org/10.3137/ao.410402.

Knipovitch, N., 1905. Hydrologische Untersuchungen im Europäischen Eismeer Annalen der Hydrographie and Maritimen Meteorologie, Sonderabdruck, 62 pp.

Krishfield, R., Toole, J., Proshutinsky, A., Timmermans, M.-L., 2008. Automated IceTethered Profilers for sea water observations under pack ice in all seasons. Journal of Atmospheric and Oceanic Technology 25, 2091-2095. http:// dx.doi.org/10.1175/2008JTECHO587.1.

Kwok, R., Maslowski, W., Laxon, S.W., 2005. On large outflows of Arctic sea ice into the Barents Sea. Geophysical Research Letters 32, L22503. http://dx.doi.org/ 10.1029/2005L024485.

Lenn, Y.D., Wiles, P.J., Torres-Valdes, S., Abrahamsen, P., Rippeth, T.P., Simpson, J.H. Bacon, S., Laxon, S.W., Polyakov, I., Ivanov, V., Kirillov, S., 2009. Vertical mixing at intermediate depth in the Arctic boundary Current. Geophysical Research Letters 36, L05601. http://dx.doi.org/10.1029/2008GL036792.

Lewis, E.L., Jones, E P. Lemke, P. Prowse, T.D. Wadhams, P. (Eds.), 2000. The Freshwater Budget of the Arctic Ocean. Kluwer Academic Publishers, Dordrecht p. 623.

Lique, C., Steele, M., 2012. Where can we find a seasonal cycle of the Atlantic water temperature within the Arctic Basin? Journal of Geophysical Research 117, C03026. http://dx.doi.org/10.1029/2011JC007612.

Loeng, H., 1991. Features of the physical oceanographic conditions in the central parts of the Barents Sea. Polar Research 10, 5-18.

Loeng, H., Ozhigin, V., Ådlandsvik, B., Sagen, H., 1993. Current Measurements in the northeastern Barents Sea. ICES C.M. 1993/C:41, Hydrographic Committee, 22 pp.

Loeng, H., Ozhigin, V., Ådlandsvik, B., 1997. Water fluxes through the Barents Sea. ICES Journal of Marine Science 54, 310-317.

Macdonald, R.W., Carmack, E.C., Wallace, D.W.R., 1993. Age of the Canada Basin deep water: a way to estimate primary production for the Arctic Ocean. Science 259, 103-104.

Maksimov, I.V., 1945. Determining the relative volume of the annual flow of Pacific water into the Arctic Ocean through Bering Strait. Problemy Arktiki 2, 51-58 (in Russian).

Malmgren, F., 1927. On the properties of sea-ice. Norw. North Pole Exp. "Maud" (1918-1925, Sci. Res.) 1 no. 5, 67 pp.

Manley, T.O., Hunkins, K., 1985. Mesoscale eddies in the Arctic Ocean. Journal of Geophysical Research 27 (90), 4911-4930.

Martinson, D.G., Steele, M., 2001. Future of the Arctic Sea Ice Cover: implications of an Antarctic Analog. Geophysical Research Letters 28 (2), 307-310. http:// dx.doi.org/10.1029/2000GL011549.

Maslowski, W., Newton, B., Schlosser, P., Semtner, A., Martinson, D., 2000. Modeling recent climate variability in the Arctic Ocean. Geophysical Research Letters 27 (22), 3743-3746.

Maslowski, W., Marble, D., Walczowski, W., Schauer, U., Clement, J.L., Semtner, A.J., 2004. On climatological mass, heat and salt transports through the Barents Sea and Fram Strait from a pan-Arctic coupled ice-ocean model simulation. Journal of Geophysical Research 109, C03032. http://dx.doi.org/10.1029/2001JC001039.

Mauritzen, C., Hansen, E., Andersson, M., Berx, B., Beszczynska-Möller, A., Burud, I., Christensen, K.H., Debernard, J., de Steur, L., Dodd, P., Gerland, S., Godøy, Ø., Hansen, B., Hudson, S., Høydalsvik, F., Ingvaldsen, R., Isachsen, P.E., Kasajima, Y. Koszalka, I., Kovacs, K.M., Køltzow, M., LaCasce, J.H., Lee, C.M., Lavergne, T., Lydersen, C., Nicolaus, M., Nilsen, F., Nøst, O.A., Orvik, K.A., Reigstad, M., Schyberg, H., Seuthe, L., Skagseth, Ø., Skarðhamar, J., Skogseth, R., Sperrevik, A. Svensen, C., Søiland, H., Teigen, S.H., Tverberg, V., Wexels Riser, C., 2011. Closing the loop - approaches to monitoring the state of the Arctic Mediterranean during the International Polar Year 2007-2008. Progress in Oceanography. http://dx.doi.org/10.1016/j.pocean.2011.02.010.

May, B.D., Kelley, D.E., 1997. Effect of baroclinicity on double-diffusive interleaving. Journal of Physical Oceanography 27, 1997-2008.

May, B.D., Kelley, D.E., 2001. Growth and steady stages of thermohaline intrusions in the Arctic Ocean. Journal of Geophysical Research 106 (C8), 16783-16794.

McGeehan, T., Maslowski, W., 2012. Evaluation and control mechanisms of volume and freshwater export through the Canadian Arctic Archipelago in a highresolution pan-Arctic ice-ocean model. Journal of Geophysical Research 117, C00D14. http://dx.doi.org/10.1029/2011JC007261.

McLaughlin, F.A., Carmack, E.C., Macdonald, R.W., Bishop, J.K.B., 1996. Physical and geochemical properties across the Atlantic/Pacific water mass boundary in the southern Canada Basin. Journal of Geophysical Research 101, 1183-1197.

McLaughlin, F.A., Carmack, E.C., MacDonald, R.W., Weaver, A.J., Smith, J., 2002. The Canada Basin 1989-1995: upstream events and far-field effects of the Barents Sea branch. Journal of Geophysical Research 107 (C7), 3082. http://dx.doi.org/ 10.1029/2001JC00090. 
McLaughlin, F.A., Carmack, E.C., Macdonald, R.W., Melling, H., Swift, J.H., Wheeler, P.A., Sherr, B.F., Sherr, E.B., 2004. The joint roles of Pacific and Atlantic-origin waters in the Canada Basin, 1997-1998. Deep-Sea Research I 51, 107-128.

McLaughlin, F.A., Carmack, E.C., Williams, W.J., Zimmermann, S., Shimada, K., Itoh, M., 2009. Joint effects of boundary currents and thermohaline intrusions on the warming of Atlantic water in the Canada Basin, 1993-2007. Journal of Geophysical Research 114. http://dx.doi.org/10.1029/2008JC005001.

McPhee, M.G., 1986. The upper ocean. In: Untersteiner, N. (Ed.), The Geophysics of Sea Ice. Plenum Press, New York, pp. 339-394.

Meincke, J., Rudels, B., Friedrich, H., 1997. The Arctic Ocean-Nordic Seas thermohaline system. ICES Journal of Marine Science 54, 283-299.

Melling, H., Agnew, T.A., Falkner, K.K., Greenberg, D.A., Craig, M.L., Münchow, A. Petrie, B., Prinsenberg, S.J., Samelson, R.M., Woodgate, R.A., 2008. In: Dickson, R.R., Meincke, J., Rhines, P. (Eds.), Arctic-Subarctic Ocean Fluxes. Springer Dordrecht, pp. 193-247.

Meredith, M.P., Heywood, K.J., Dennis, P.F., Goldson, L.E., White, R., Fahrbach, E., Østerhus, S., 2001. Freshwater fluxes through the western Fram Strait. Geophysical Research Letters 28, 615-618.

Midttun, L., 1985. Formation of dense bottom water in the Barents Sea. Deep-Sea Research 32, 1233-1241.

Morison, J.H., Steele, M., Anderson, R., 1998. Hydrography of the upper Arctic Ocean measured form the nuclear submarine USS Pargo. Deep-Sea Research I 45, 15 38.

Morison, J.H., Aagaard, K., Falkner, K.K., Hatakeyama, K., Moritz, R., Overland, J.E. Perovich, D., Shimada, K., Steele, M., Takizawa, T., Woodgate, R., 2002. North Pole environmental observatory delivers early results. Eos, Transaction American Geophysical Union 83, 357-361.

Morison, J., Steele, M., Kikuchi, T., Falkner, K.K., Smethie, W., 2006. Relaxation of central Arctic Ocean hydrography to pre-1990 climatology. Geophysica Research Letters 33, L17604. http://dx.doi.org/10.1029/2006GL026826.

Morison, J., Kwok, R., Peralta-Ferriz, C., Alkire, M., Rigor, I., Andersen, R., Steele, M. 2012. Changing Arctic Ocean freshwater pathways. Nature 481, 66-70. http:/| dx.doi.org/10.1038/nature10705.

Mosby, H., 1962. Water, mass and heat balance of the North Polar Sea and of the Norwegian Sea. Geofysiske Publikasjoner 24 (II), 289-313.

Muench, R.D., 1971. The Physical Oceanography of the Northern Baffin Bay Region The Baffin Bay - North Water Project. Scientific Report No 1. Arctic Institute of North America, 150 pp.

Münchow, A., Melling, H., 2008. Ocean current observations from Nares Strait to the west of Greenland: interannual to tidal variability and forcing. Journal of Marine Research 66 (6), 801-833.

Münchow, A., Melling, H., Falkner, K.K., 2006. An observational estimate of volume and freshwater flux leaving the Arctic Ocean through Nares Strait. Journal of Physical Oceanography 36, 2025-2041. http://dx.doi.org/10.1175/JPO2962.1.

Nansen, F., 1902. Oceanography of the North Polar Basin. The Norwegian North Polar Expedition 1893-1896. Scientific Results (9), 427 pp.

Nansen, F., 1906. Northern Waters, Captain Roald Amundsen's Oceanographic Observations in the Arctic Seas in 1901. Videnskab-Selskabets Skrifter 1. Matematisk-Naturvidenskabelig Klasse 1, Kristiania, 1-145.

Nansen, F., 1912. Das Bodenwasser und die Abkühlung des Meeres. Internationale Revue des Gesamten Hydrobiologie und Hydrographie 5, 42.

Nansen, F., 1915. Spitsbergen Waters. Videnskabs-selskabets skrifter I. MatematiskNaturvidenskabelig klasse I (3), 145.

Neal, D.A., Neshyba, S., Denner, W., 1969. Thermal stratification in the Arctic Ocean. Science 166, 373-374.

Neshyba, S., Neal, V.T., Denner, W., 1971. Temperature andconductivity measurements under Ice Island T-3. Journal of Geophysical Research 76, 8107-8120.

Newton, J.L., Coachman, L.K., 1974. Atlantic water circulation in the Canada Basin. Arctic 27, 297-303.

Newton, J.L., Aagaard, K., Coachman, L.K., 1974. Baroclinic eddies in the Arctic Ocean. Deep-Sea Research 21, 707-719.

Nikiferov, E.G. and Shpaiker, A.O. 1980. Principle of large-scale variations of the Arctic Ocean hydrography. Hydrometeizdat, Leningrad, $269 \mathrm{pp}$.

Nikolopoulos, A., Pickart, R.S., Frantantoni, P.S., Shimada, K., Torres, D.J., Jones, E.P., 2009. The western Arctic boundary current at $152^{\circ} \mathrm{W}$ : structure, variability and transport. Deep-Sea Research II 56, 1164-1181. http://dx.doi.org/10.1016/j, dsr2.2008.10.014

Ortiz, J.D., Falkner, K.K., Matrai, P.A., Woodgate, R.A. (Eds.), 2011. The Changing Arctic Ocean: Special Issue on the International Polar Year. Oceanography 24(3), 14-279.

Östlund, H.G. Hut, G., 1984. Arctic Ocean water mass balance from isotope data. Journal of Geophysical Research 89, 6373-6381.

Padman, L., 1995. Small-scale physical processes in the Arctic Ocean. In: Smith Jr. W.O., Grebmeier, J.M. (Eds), Arctic Oceanography, Marginal Ice Zones and Continental Shelves, AGU 49, Washington, DC, pp. 131-182.

Padman, L., Dillon, T.M., 1987. Vertical heat fluxes through the Beaufort Sea thermohaline staircases. Journal of Geophysical Research 92, 10799-10806.

Padman, L., Dillon, T.M., 1988. On the horizontal extent of the Canada Basin themohaline steps. Journal of Physical Oceanography 18, 1458-1462.

Perkin, R.G., Lewis, E.L., 1984. Mixing in the West Spitsbergen current. Journal of Physical Oceanography 14, 1315-1325.

Petermann, A., 1865. Der Nordpol und Südpol, die Wichtigkeit ihrer Erforschung in geographischer und kulturhistorischer Beziehung. Mit Bemerkungen über die Strömungen der Polar-Meere. Pet. Mitt., Gotha, pp. 146-160.
Peterson, I., Hamilton, J., Prinsenberg, S., Pettipas, R., 2012. Wind-forcing of volume transports through Lancaster Sound. Journal of Geophysical Research 117 C11018. http://dx.doi.org/10.1029/2012JC008140.

Pfirman, S.L., Bauch, D., Gammelsröd, T., 1994. The northern Barents Sea: water mass distribution and modification. In: Johannessen, O.M., Muench, R.D. Overland, J.E. (Eds.), The Role of the Polar Oceans in Shaping the Global Climate. American Geophysical Union, Washington, DC, pp. 77-94.

Pickart, R.S., 2004. Shelfbreak circulation in the Alaskan Beaufort Sea: mean structure and variability. Journal of Geophysical Research 109, C04024. http:// dx.doi.org/10.1029/2003JC001912.

Pickart, R.S., Weingartner, T.J., Zimmermann, S., Torres, D.J., Pratt, L.J., 2005. Flow of winter-transformed water in the western arctic. Deep-Sea Research II 52, 3175 3198.

Polyakov, I.V., Alekseev, G.V., Timokhov, L.A., Bhatt, U.S., Colony, R.L., Simmons, H.L., Walsh, D., Walsh, J.E., Zakharov, V.F., 2004. Variability of the Intermediate Atlantic Water of the Arctic Ocean over the last 100 years. Journal of Climate 17. 4485-4494.

Polyakov, I.V., Beszczynska-Möller, A., Carmack, E., Dmitrenko, I., Fahrbach, E., Frolov, I., Gerdes, R., Hansen, E., Holfort, J., Ivanov, V., Johnson, M., Karcher, M., Kauker, F., Morison, J., Orvik, K., Schauer, U., Simmons, H., Skagseth, Ø., Sokolov, V., Steele, M., Timokhov, L., Walsh, D., Walsh, J., 2005. One more step towards a warmer Arctic. Geophysical Research Letters 32, L17605, http://dx.doi.org/ 10.10292005GL023740.

Polyakov, I.V., Timokhov, L.A., Alexeev, V.A., Bacon, S., Dmitrenko, I.A., Fortier, L., Frolov, I.E., Gascard, J.-C., Hansen, E., Ivanov, V.I., Laxon, S., Mauritzen, C., Perovich, D., Shimada, K., Simmons, H.L., Sokolov, V.T., Steele, M., Toole, J., 2010 Arctic warming contributes to reduced polar ice cap. Journal of Physical Oceanography 40, 2743-2756. http://dx.doi.org/10.1175/2010JPO4339.1.

Polyakov, I.V., Alekseev, V.A., Ashik, I.M., Bacon, S., Beszczynska-Möller, A., Dmitrenko, I. Fortier, L., Gascard, J.-C., Hansen, E., Hölemann, J., Ivanov, V.V. Kikuchi, T., Krillov, S., Lenn, Y.-D., Piechura, J., Repina, I., Timokhov, L.A., Walczowski, W., Woodgate, R., 2011. Fate of the early-2000s Arctic warm pulse. Bulletin of the American Meteorological Society 92, 561-566.

Polyakov, I.V., Walsh, J.E., Kwok, R., 2012a. Recent changes in the Arctic multiyear sea ice coverage and its likely causes. Bulletin of the American Meteorological Society 96, 145-151. http://dx.doi.org/10.1175/BAMS-D-11-00070.1.

Polyakov, I.V., Pnyushkov, A.V., Rember, R., Ivanov, V.I., Lenn, Y.-D., Padman, L. Carmack, E.C., 2012b. Mooring-based observations of double-diffusive staircases over the Laptev Sea slope. Journal of Physical Oceanography 42 , 95-109. http://dx.doi.org/10.1175/2011JP04606.

Prinsenberg, S.J., Hamilton, J., 2005. Monitoring the volume, freshwater and heat fluxes passing through Lancaster Sound in the Canadian Arctic Archipelago. Atmosphere-Ocean 43, 1-22.

Proshutinsky, A., Johnson, M.A., 1997. Two circulation regimes of the wind-driven Arctic Ocean. Journal of Geophysical Research 102, 12493-12514. http:// dx.doi.org/10.1029/97JC00738.

Proshutinsky, A., Krishfield, R., Timmerman, M.-L., Toole, J., Carmack, E.C. McLaughlin, F.A., Williams, W.J., Zimmermann, S., Itoh, M., Shimada, K., 2009. Beaofort Gyre Reservoir: state and variability from observations. Journal of Geophysical Research 114, C00A10. http://dx.doi.org/10.1029/2008JC005104.

Proshutinsky, A. Aksenov, Y. Clement Kinney, J.C., Gerdes, R, Golubeva, E., Holland, D., Holloway, G., Jahn, A., Johnson, M., Popova, E., Steele, M., Watanabe, E., 2011. Recent advances in Arctic Ocean studies employing models from tha Arctic Ocean Model Intercomparison Project. Oceanography 24 (3), 102-113.

Quadfasel, D., Gascard, J.-C., Koltermann, K.-P., 1987. Large-scale oceanography in Fram Strait during the 1984 Marginal Ice Zone experiment. Journal of Geophysical Research 92, 6719-6728.

Quadfasel, D., Rudels, B., Kurz, K., 1988. Outflow of dense water from a Svalbard fjord into the Fram Strait. Deep-Sea Research 35, 1143-1150.

Quadfasel, D., Sy, A., Wells, D., Tunik, 1991. Warming of the Arctic. Nature 350, 385.

Quadfasel, D., Rudels, B., Selchow, S., 1992. The Central Bank vortex in the Barents Sea: water mass transformation and circulation. ICES Marine Science Symposia 195, 40-51.

Quadfasel, D., Sy, A., Rudels, B., 1993. A ship of opportunity section to the North Pole: upper ocean temperature observations. Deep-Sea Research 40, 777-789.

Rabe, B., Schauer, U., Mackensen, A., Karcher, M., Hansen, E., Beszczynska-Möller, A., 2009. Freshwater components and transports in the Fram Strait: recent observations and changes since the late 1990s. Ocean Science 5, 219-233. http://dx.doi.org/10.5194/os-5-219-2009.

Rabe, B., Münchow, A., Johnson, H.L., Melling, H., 2010. Nares Strait hydrography and salinity field from a 3-year moored array. Journal of Geophysical Research 11t5, C07010. http://dx.doi.org/10.1029/2009JC005966.

Rabe, B., Karcher, M., Schauer, U., Toole, J.M., Krishfield, R.A., Pisarev, S., Kauker, F., Gerdes, R., Kikuchi, T., 2011. An assessment of the Arctic Ocean freshwater content changes from the 1990s to the 2006-2008 period. Deep-Sea Research I 58, 173-185. http://dx.doi.org/10.1016/j.dsr.2010.12.002.

Rabe, B., Dodd, P.A., Hansen, E., Falck, E., Schauer, U., Mackensen, A., BeszczynskaMöller, A., Kattner, G., Rohling, E.J., Cox, K., 2013. Liquid export of Arctic freshwater components through Fram Strait 1998-2011. Ocean Science 9, 91109. http://dx.doi.org/10.5194/os-9-91-2013.

Rahmstorf, S., 1995. Bifurcation of the Atlantic thermohaline circulation in response to changes in the hydrological cycle. Nature 378, 145-149.

Riis-Carstensen, E., 1936. The "Godthaab" expedition 1928. The hydrographic work and material. Meddelelser om Grønland 78 (3), 101. 
Roach, A.T., Aagaard, K., Pease, C.H., Salo, A., Weingartner, T., Pavlov, V., Kulakov, M., 1995. Direct measurements of transport and water properties through the Bering Strait. Journal of Geophysical Research 100, 18443-18457.

Rooth, C., 1982. Hydrology and ocean circulation. Progress in Oceanography 11, 131-149.

Rudels, B., 1986a. The $\theta S$ relations in the northern seas: implications for the deep circulation. Polar Research 4, 133-159.

Rudels, B., 1986b. The outflow of Polar Water through the Arctic Archipelago and the oceanographic conditions in Baffin Bay. Polar Research 4, 161-180.

Rudels, B., 1987. On the mass balance of the Polar Ocean, with special emphasis on the Fram Strait. Norsk Polarinstitutt Skrifter, Oslo 188, 53 pp.

Rudels, B., 1993. High latitude ocean convection. In: Stone, D., Runcorn, S.K. (Eds.), Flow and Creep in the Solar System. Kluwer Acad. Publ., Dordrecht, pp. 323356.

Rudels, B., 1995. The thermohaline circulation of the Arctic Ocean and the Greenland Sea. Philosophical Transactions of the Royal Society of London 352, 287-299.

Rudels, B., 2010. Constraints on exchanges in the Arctic Mediterranean - do they exist and can they be of use? Tellus 62A, 109-122.

Rudels, B., 2011. Volume and freshwater transports through the Canadian Arctic Archipelago - Baffin Bay system. Journal of Geophysical Research 116, C00D10. http://dx.doi.org/10.1029/2011JC007019.

Rudels, B., 2012. Arctic Ocean circulation and variability - advection and external forcing encounter constraints and local processes. Ocean Science 8, 261-286. http://dx.doi.org/10.5194/os-8-261-2012.

Rudels, B., Friedrich, H.J., 2000. The transformations of Atlantic water in the Arctic Ocean and their significance for the freshwater budget. In: Lewis, E.L., Jones, E.P., Lemke, P., Prowse, T.D. (Eds.), The Freshwater Budget of the Arctic Ocean, NATO Science Series, 2 Environmental Security, vol. 70. Kluwer Academic Publishers, Dordrecht, pp. 503-532.

Rudels, B., Jones, E.P., Anderson, L.G., Kattner, G., 1994. On the intermediate depth waters of the Arctic Ocean. In: Johannessen, O.M., Muench, R.D., Overland, J.E. (Eds.), The Role of the Polar Oceans in Shaping the Global Climate. American Geophysical Union, Washington, DC, pp. 33-46.

Rudels, B., Anderson, L.G., Jones, E.P., 1996. Formation and evolution of the surface mixed layer and the halocline of the Arctic Ocean. Journal of Geophysical Research 101, 8807-8821.

Rudels, B., Björk, G., Muench, R.D., Schauer, U., 1999a. Double-diffusive layering in the Eurasian Basin of the Arctic Ocean. Journal of Marine Systems 21, 3-27.

Rudels, B., Friedrich, H.J., Hainbucher, D., Lohmann, G., 1999b. On the parameterisation of oceanic sensible heat loss to the atmosphere and to ice in an ice-covered mixed layer in winter. Deep-Sea Research II 46, 1385-1425.

Rudels, B., Friedrich, H.J., Quadfasel, D., 1999c. The Arctic circumpolar boundary current. Deep-Sea Research II 46, 1023-1062.

Rudels, B., Muench, R.D., Gunn, J., Schauer, U., Friedrich, H.J., 2000a. Evolution of the Arctic Ocean boundary current north of the Siberian shelves. Journal of Marine Systems 25, 77-99.

Rudels, B., Meyer, R., Fahrbach, E., Ivanov, V.V., Østerhus, S., Quadfasel, D., Schauer, U., Tverberg, V., Woodgate, R.A., 2000b. Water mass distribution in Fram Strait and over the Yermak Plateau in summer 1997. Annales Geophysicae 18, 687705.

Rudels, B., Jones, E.P., Schauer, U., Eriksson, P., 2004. Atlantic sources of the Arctic Ocean surface and halocline waters. Polar Research 23, 181-208.

Rudels, B., Björk, G., Nilsson, J., Winsor, P., Lake, I., Nohr, C., 2005. The interactions between waters from the Arctic Ocean and the Nordic Seas north of Fram Strait and along the East Greenland Current: results from the Arctic Ocean-02 Oden expedition. Journal of Marine Systems 55, 1-30.

Rudels, B., Marnela, M., Eriksson, P., 2008. Constraints on estimating mass, heat and freshwater transport in the Arctic Ocean: an exercise. In: Dickson, R.R., Meincke, J., Rhines, P. (Eds.), Arctic-Subarctic Ocean Fluxes. Springer, Dordrecht, pp. 315341.

Rudels, B., Kuzmina, N., Schauer, U., Stipa, T., Zhurbas, V., 2009. Double-diffusive convection in the Arctic Ocean - distribution and importance. Geophysica 45, 199-213.

Rudels, B., Korhonen, M., Budéus, G., Beszyczynska-Möller, A., Schauer, U., Nummelin, A., Quadfasel, D., Valdimarsson, H., 2012. The East Greenland Current and its impact on the Nordic Sea: observed trends in the recent decade. ICES Journal of Marine Sciences 65 (5), 841-851. http://dx.doi.org/10.1093/ icesjms/fss079.

Rudels, B., Schauer, U., Björk, G., Korhonen, M., Pisarev, S., Rabe, B., Wisotski, A., 2013. Observations of water masses and circulation with focus on the Eurasian basin of the Arctic Ocean from the 1990s to the late 2000s. Ocean Science 9, 147-169. http://dx.doi.org/10.5194/os-9-147-2013.

Ryder, C., 1891-1892. Tidligere Ekspeditioner til Grønlands Østkyst nord for 66o Nr. Br., Geogr. Tids. Bd. 11, København, pp. 62-107.

Sadler, H.E., 1976. Water, heat and salt transports through Nares Strait, Ellesmere Island. Journal of the Fisheries Board of Canada 33 (10), 2286-2295.

Salmon, D.K., McRoy, C.P., 1994. Nutrient-based tracers in the Western Arctic: a new lower halocline defined. In: Johannessen, O.M., Muench, R.D. Overland, J.E. (Eds.), The Polar Oceans and Their Role in Shaping the Global Environment, AGU Geophysical Monographs. American Geophysical Union, Washington, DC, pp. 47-61, 85.

Schauer, U., 1995. The release of brine-enriched shelf water from Storfjord into the Norwegian Sea. Journal of Geophysical Research 100, 16015-16028.

Schauer, U., Beszczynska-Möller, A., 2009. Problems with estimation and interpretation of oceanic heat transport - conceptual remarks for the case of
Fram Strait in the Arctic Ocean. Ocean Science 487-494. http://dx.doi.org/ 10.5194/os-5.487-2009.

Schauer, U., Fahrbach, E., 1999. A dense bottom water plume in the western Barents Sea: downstream modification and interannual variability. Deep-Sea Research 1 46, 2095-2108.

Schauer, U., Muench, R.D., Rudels, B., Timokhov, L., 1997. Impact of eastern Arctic Shelf water on the Nansen Basin intermediate layers. Journal of Geophysica Research 102, 3371-3382.

Schauer, U., Rudels, B., Jones, E.P., Anderson, L.G., Muench, R.D., Björk, G., Swift, J.H Ivanov, V., Larsson, A.-M., 2002a. Confluence and redistribution of Atlantic water in the Nansen, Amundsen and Makarov basins. Annales Geophysicae 20, 257-273.

Schauer, U., Loeng, H., Rudels, B., Ozhigin, V.K., Dieck, W., 2002b. Atlantic Water flow through the Barents and Kara Seas. Deep-Sea Research I 49, 2281-2298.

Schauer, U., Fahrbach, E., Østerhus, S., Rohardt, G., 2004. Arctic Warming through the Fram Strait: oceanic heat transports from 3 years of measurements. Journal of Geophysical Research 109, C06026. http://dx.doi.org/10.1029/2003JC001823.

Schauer, U., Beszczynska-Möller, A., Walczowski, W., Fahrbach, E., Piechura, J. Hansen, E., 2008. Variation of measured heat flow through the Fram Strait between 1997-2006. In: Dickson, R.R., Meincke, J., Rhines, P. (Eds.), ArcticSubarctic Ocean Fluxes. Springer, Dordrecht, pp. 65-85.

Schlosser, P., Bauch, D., Fairbanks, R., Bönisch, G., 1994. Arctic river-runoff: mean residence time on the shelves and in the halocline. Deep-Sea Research, 1053 1068.

Serreze, M.C., Barrett, A., Slater, A.J., Woodgate, R.A., Aagaard, K., Steele, M., Moritz R., Meredith, M., Lee, C., 2006. The large-scale freshwater cycle in the Arctic Journal of Geophysical Research 111, C11010. http://dx.doi.org/10.1029/ 2005JC003424.

Shimada, K., McLaughlin, F.A., Carmack, E.C., Proshutinsky, A., Nishino, S., Itoh, M. 2004. Penetration of the 1990s warm temperature anomaly of the Atlantic Water in the Canada basin. Geophysical Research Letters 31, L20301. http:// dx.doi.org/10.1029/2004GL020860.

Shimada, K., Itoh, M., Nishino, S., McLaughlin, F.A. Carmack, E., Proshutinsky, A 2005. Halocline structure in the Canada Basin of the Arctic Ocean. Geophysical Research Letters 32, L03605. http://dx.doi.org/10.1029/2004GL021358.

Shirshov, P.P., 1944. Scientific Results of the Drift of Station "North Pole". Doklad na obshchem sobr. AN SSSR, Moscow, 14-17, fevralya (in Russian).

Sirevaag, A., Fer, Ilker., 2012. Vertical heat transfer in the Arctic Ocean: the role of double-diffusive mixing. Journal of Geophysical Research 117, C07010. http:/ dx.doi.org/10.1029/2012JC007910.

Skagseth, Ø., 2008. Recirculation of Atlantic water in the western Barents Sea Geophysical Research Letters 35, L11606. http://dx.doi.org/10.1029/ 2008GL033785.

Skagseth, Ø., Furevik, T., Ingvaldsen, R., Loeng, H., Mork, K.A., Orvik, K.A., Ozhigin, V., 2008. Volume and heat transports to the Arctic Ocean via the Norwegian and Barents seas, in: Arctic-Subarctic Ocean Fluxes. In: Dickson, R.R., Meincke, J., Rhines, P. (Eds.), Arctic-Subarctic Ocean Fluxes. Springer, Dordrecht, pp. 45-64.

Skagseth, Ø., Drinkwater, K.F., Terrile, E., 2011. Wind- and buoyancy-induced transport of the Norwegian coastal current in the Barents Sea. Journal of Geophysical Research 116, C08007. http://dx.doi.org/10.1029/2011JC006996, 5.

Smethie, W.M., Schlosser, P., Bönisch, G., 2000. Renewal and circulation of intermediate waters in the Canadian Basin observed on the SCICEX 96 cruise Journal of Geophysical Research 105, 1105-1121.

Smith, E.H., Soule, F.M., Mosby, O., 1937. The Marion and General Greene Expeditions to Davis Strait and Labrador Sea under Direction of the United States Coast Guard 1928-1931-1933-1934-1935. Scientific Results. Part 2. Physical Oceanography. US Treasure Department, Coast Guard Bulletin No. 19. US Printing Office, Washington, $258 \mathrm{pp}$.

Smith, J.N., Ellis, K.M., Boyd, T., 1999. Circulation features in the central Arctic Ocean revealed by nuclear fuel reprocessing tracers from Scientific Ice Expeditions 1995 and 1996. Journal of Geophysical Research 104, 29663-29667.

Sokolov, A.L., 1962. Drift of sea ice in the Arctic Basin and changes in ice conditions over the northern sea route. Problems of Arctic and Antarctic, English Translation 11, j1-j20.

Spall, M.A., Pickart, R.S., Frantantoni, P.S., Plueddemann, A.J., 2008. Western Arctic shelfbreak eddies: formation and transports. Journal of Physical Oceanography 38, 1644-1668.

Spreen, G., Kern, S., Stammer, D., Hansen, E., 2009. Fram Strait sea ice volume export estimated between 2003 and 2008 from satellite data. Geophysical Research Letters 36, L19502. http://dx.doi.org/10.1029/2009GL039591.

Steele, M., Boyd, T., 1998. Retreat of the cold halocline layer in the Arctic Ocean. Journal of Geophysical Research 103, 10419-10435.

Steele, M., Morison, J.H., Curtin, T.B., 1995. Halocline water formation in the Barents Sea. Journal of Geophysical Research 100, 881-894.

Steele, M., Thomas, D., Rothrock, D., Martin, S., 1996. A simple model study of the Arctic Ocean freshwater balance, 1979-1985. Journal of Geophysical Research 101, 20833-20848.

Steele, M., Morison, J.H., Ermold, W., Rigor, I., Ortmeyer, M., 2004. Circulation of summer Pacific Water in the Arctic Ocean. Journal of Geophysical Research 109, C02027. http://dx.doi.org/10.1029/2003JC002009.

Stigebrandt, A., 1981. A model for the thickness and salinity of the upper layers of the Arctic Ocean and the relation between the ice thickness and some external parameters. Journal of Physical Oceanography 11, 1407-1422.

Stigebrandt, A., 1984. The North Pacific: a global-scale estuary. Journal of Physical Oceanography 14, 464-470. 
Stommel, H., 1961. Thermohaline convection with two stable regimes of flow. Tellus 13, 224-230.

Sverdrup, H.U., 1926. Dynamics of Tides on the North Siberian Shelf. Geof. Publ. 4 no. 5 , Oslo.

Sverdrup, H.U., Johnson, M.W., Fleming, R.H., 1942. The Oceans: Their Physics, Chemistry and General Biology. Prentice-Hall, New York, 1042 pp.

Swift, J.H., Jones, E.P., Carmack, E.C., Hingston, M., Macdonald, R.W., McLaughlin, F.A., Perkin, R.G., 1997. Waters of the Makarov and Canada Basins. Deep-Sea Research II 44, 1503-1529.

Swift, J.H., Aagaard, K., Timokhov, L., Nikiferov, E.G., 2005. Long-term variability of Arctic Ocean waters: evidence from reanalysis of the EWG data set. Journal of Geophysical Research 110, C03012. http://dx.doi.org/10.1029/2004JC002312.

Tang, C.C.L., Ross, C.-K., Yao, T., Petrie, B., DeTracey, B.M., Dunlap, E., 2004. The circulation, water masses and sea-ice of Baffin Bay. Progress in Oceanography $63,183-228$.

Tantsiura, A.I., 1959. On the currents of the Barents Sea. Transactions of the Polar Scientific Research Institute of Marine Fisheries and Oceanography (PINRO) 11, 35-53 (in Russian).

Thompson, D.W.J., Wallace, J.M., 1998. The Arctic Oscillation signature in the wintertime geopotential height and temperature fields. Geophysical Research Letters 25, 1297-1300.

Timmermans, M.-L., Garrett, C., 2006. Evolution of the deep water in the Canadian Basin in the Arctic Ocean. Journal of Physical Oceanography 36, 866-874.

Timmermans, M.-L., Garrett, C., Carmack, E., 2003. The thermohaline structure and evolution of the deep waters in the Canada Basin, Arctic Ocean. Deep-Sea Research I 50, 1305-1321. http://dx.doi.org/10.1016/S0967(03)00125-0.

Timmermans, M.-L., Winsor, P., Whitehead, J.A., 2005. Deep-water flow over the Lomonosov Ridge in the Arctic Ocean. Journal of Physical Oceanography 35, 1489-1493.

Timmermans, M.-L., Toole, J., Krishfield, R., Winsor, P., 2008. Ice-Tethered Profiler observations of the double-diffusive staircase in the Canada Basin thermocline. Journal of Geophysical Research 113, C00A02. http://dx.doi.org/10.1029/ 2008JC004829.

Timofeyev, V.T., 1960. Water masses of the Arctic basin. Gidromet. Izdat., Leningrad (in Russian).

Timofeyev, V.T., 1962. The movement of Atlantic Water and heat into the Arctic sea basin. Deep-Sea Research 9, 358-361.

Timofeyev, V.T., 1963. Interaction of the Arctic Ocean waters with Atlantic and Pacific waters. Okeanologiya 3, 569-578.

Toole, J.M., Krishfield, R.A., Timmermans, M.-L., Proshutinsky, A., 2011. The IceTethered Profiler, Argo of the Arctic. Oceanography 24 (3), 126-135.

Treshnikov, A.F., 1997. Water masses of the Arctic Basin. In: Dunbar, M. (Ed.), Polar Oceans. Arctic Institute of North America, pp. 17-31.

Treshnikov, A.F., Baranov, G.I., 1972. Structure and circulation of water in the Arctic Basin. Leningrad 10, 158.

Tsubouchi, T., Bacon, S., Naveira Garabato, A.C., Aksenov, Y., Laxon, S.W., Fahrbach, E., Beszczynska-Möller, A., Hansen, E., Lee, C.M., Ingvaldsen, R.B., 2012. The Arctic Ocean in summer: a quasi-synoptic inverse estimate of boundary fluxes and water mass transformation. Journal of Geophysical Research 117, C01024. http://dx.doi.org/10.1029/2011JC007174.
Turner, J.S., 1973. Buoyancy Effects in Fluids. Cambridge Univ. Press, Cambridge, $367 \mathrm{pp}$.

Vowinckel, E., Orvig, S., 1962. Water balance and heat flow of the Arctic Ocean. Arctic 15, 205-223.

Vowinckel, E., Orvig, S., 1970. The climate of the North Polar Basin. In: Orvig, S. (Ed.), World Climate Surve, Climates of the Polar Regions, vol. 14. Elsevier, Amsterdam, p. 370.

Walczowski, W., Piechura, J., 2006. New evidence of warming propagating toward the Arctic Ocean. Geophysical Research Letters 33, L12601. http://dx.doi.org/ 10.1029/2006GL025872.

Walsh, D., Carmack, E.C., 2003. The nested structure of Arctic thermohaline intrusions. Ocean Modelling 5, 267-289.

Walsh, D., Polyakov, I.V., Timokhov, L., Carmack, E., 2007. Thermohaline structure and variability in the eastern Nansen Basin as seen from historical data. Journal of Marine Research 65, 685-714.

Weyl, P.K., 1968. The role of the oceans in climate change. Meteorological Monographs 8, 37-62.

Wijffels, S.E., Schmitt, R.W., Bryden, H.L., Stigebrandt, A., 1992. Transport of freshwater by the oceans. Journal of Physical Oceanography 22, 155-162.

Winsor, P., Björk, G., 2000. Polynya activity in the Arctic Ocean from 1958 to 1997. Journal of Geophysical Research 105, 8789-8803.

Winsor, P., Chapman, D.C., 2002. Distribution and interannual variability of dense water production from coastal polynyas on the Chukchi shelf. Journal of Geophysical Research 107 (C7), 3079. http://dx.doi.org/10.1029/2001JC000984.

Winsor, P., Chapman, D.C., 2004. Pathways of Pacific water across the Chukchi Sea: a numerical model study. Journal of Geophysical Research 109, C03002. http:// dx.doi.org/10.1029/2003JC001962.

Woodgate, R.A., Aagaard, K., 2005. Revising the Bering Strait freshwater flux into the Arctic Ocean. Geophysical Research Letters 32, L02602, Doi: 1029/ 2004GL021747.

Woodgate, R.A., Aagaard, K., Muench, R.D., Gunn, J., Björk, G., Rudels, B., Roach, A.T., Schauer, U., 2001. The Arctic Ocean boundary current along the Eurasian slope and the adjacent Lomonosov Ridge: water mass properties, transports and transformations from moored instruments. Deep-Sea Research I 48, 1757-1792.

Woodgate, R.A., Aagaard, K., Swift, J.H., Falkner, K.K., Smethie, W.M., 2005a. Pacific ventilation of the Arctic Ocean's lower halocline by upwelling and diapycnal mixing over the continental margin. Geophysical Research Letters 32, L18609. http://dx.doi.org/10.1029/2005GL023999.

Woodgate, R.A., Aagaard, K., Weingartner, T., 2005b. A year in the physical oceanography of the Chukchi Sea: Moored measurements from autumn 1990-1991. Deep-Sea Research II 52, 3116-3149. http://dx.doi.org/10.1016/ jdsr2.2005.10.1016.

Worthington, L.V., 1953. Oceanographic results of Project Skijump I and II. Transactions. American Geophysical Union 34 (4), 543-551.

Wüst, G., 1941. Relief und Bodenwasser im Nordpolarbecken. Zeitschrift der Gesellschaft für Erdkunde zu Berlin 5 (6), 163-180.

Yamamoto-Kawai, M., McLaughlin, F.A., Carmack, E.C., Nishino, S., Shimada, K. Kurita, K., 2009. Surface freshening of the Canada Basin, 2003-2007: river runoff versus sea ice meltwater. Journal of Geophysical Research 114, C00A05. http://dx.doi.org/10.1029/2008JC005000. 